\title{
Kognitív epidemiológia - Az intelligenciaszint prospektív összefüggése a szomatikus és pszichiátriai betegségrizikóval
}

\author{
UJMA PRZEMYSLAW PÉTER ${ }^{1,2}$ \\ ${ }^{1}$ Semmelweis Egyetem, Magatartástudományi Intézet, Budapest \\ ${ }^{2}$ Országos Klinikai Idegtudományi Intézet, Budapest
}

(Beérkezett: 2020. augusztus 10.; elfogadva: 2021. január 6.)

\begin{abstract}
A kognitív epidemiológia az intelligencia és az egészségi állapot összefüggésének tudománya. A modern, sokszor több százezer fős, teljes populációkon végzett kognitív epidemiológiai vizsgálatok eredményei alapján a magasabb premorbid intelligencia gyakorlatilag valamennyi mentális betegség, illetve pszichiátriai probléma alacsonyabb kockázatával függ össze. A magasabb premorbid intelligencia a halálozás, a szív- és érrendszeri betegségek, a metabolikus betegségek, a rossz egészség-magatartás és számos kisebb népegészségügyi jelentőségú betegség előfordulásával is negatívan függ össze; a légzőszervi betegségekkel és a dohányzáshoz nem köthető daganatokkal azonban gyenge vagy hiányzik az összefüggés. A mentális betegségekkel való összefüggést nem, a szomatikus betegségekkel és a mortalitással való összefüggést azonban részben mediálják a felnőttkori szocioökonómiai státusz mutatói. A speciális vizsgálati elrendezések - úgymint ikerkontroll-vizsgálatok, pszeudoexperimentális vizsgálatok, valamint a mendeli randomizáció módszerét használó molekuláris genetikai vizsgálatok - eredményei arra utalnak, hogy az intelligencia és az egészség közötti kapcsolat jelentős részét genetikai tényezők közvetítik, de a szomatikus egészségre a magasabb intelligencia következményeként elérhető jobb szocioökonómiai státusz is szerény hatást gyakorol.
\end{abstract}

Kulcsszavak: intelligencia, IQ, egészségi állapot, vezető halálokok, pszichiátriai betegségek, kognitív epidemiológia

\section{Bevezetés - \\ Az intelligencia, a kognitív epidemiológia és a vizsgálatok módszertana}

\subsection{Az intelligencia}

A pszichológiában, az oktatásban és segédtudományaikban a 19. század végétől használnak teljesítményteszteket a kognitív képességek mérésére (Gibbons \& Warne, 2019). A pszichológia egyik legjobban replikálódó ered-

\footnotetext{
* Levelezési cím: dr. Ujma Przemyslaw Péter, Semmelweis Egyetem, Magatartástudományi Intézet, 1089 Budapest, Nagyvárad tér 4. E-mail: peteru88@gmail.com
} 
ménye az a tény, hogy a teljesítménytesztek eredményei gyakorlatilag kivétel nélkül pozitívan korrelálnak, azaz az egyik teljesítményteszten az átlagnál jobban teljesítő személy az összes többi teszten is az átlagnál jobban teljesít (Spearman, 1904; Warne \& Burningham, 2019). Ezért a teljesítménytesztek eredményének főkomponens-elemzése - vagy a gyakorlatban, az IQ-tesztek kiértékelésekor sokszor azok egyszerú összpontszáma - révén a teszteket kitöltő, illetve elvégző személyeknél egy területáltalános kognitív képesség (g-faktor, „intelligencia”) számítható vagy becsülhető. Az így mért pszichometriai intelligencia időben stabil (Deary, Pattie, \& Starr, 2013; Gow és mtsai, 2011; Larsen, Hartmann, \& Nyborg, 2008; Lyons és mtsai, 2009), a különböző tesztek között magas konvergens validitást mutat (Floyd, Reynolds, Farmer, \& Kranzler, 2013; Johnson, Bouchard, Krueger, McGue, \& Gottesman, 2004; Johnson, Nijenhuis, \& Bouchard, 2008; Major, Johnson, \& Bouchard, 2011), és prospektív vizsgálatokban nemcsak az iskolai teljesítménnyel (Roth és mtsai, 2015), hanem a széles körben vett társadalmi siker legkülönbözőbb mutatóival, például a jövedelemmel, az iskolai végzettséggel, a végzett munka presztízsével, a korai iskolaelhagyással, a búnözéssel vagy a szociális juttatások igénybevételével is összefügg (Hegelund, Flensborg-Madsen, Dammeyer, \& Mortensen, 2018; Hegelund, FlensborgMadsen, Dammeyer, Mortensen, \& Mortensen, 2019; Herrnstein \& Murray, 2010; Schmidt, Oh, \& Shaffer, 2016; Strenze, 2007, 2015). A kognitív epidemiológia tudománya az intelligenciateszteknek egy speciális területen - nevezetesen az egészségi mutatókkal kapcsolatban - való prediktív validitásával foglalkozik (Deary \& Batty, 2007).

A pszichológia korai, naiv elméletei sokszor alapvetően negatív összefüggést tételeztek fel az intelligencia és a fizikai vagy mentális egészség között. A pszichometria egyik amerikai úttörője, Lewis Terman például meglepő felfedezésként tudta leírni, hogy az általa vizsgált, a pszichometriai teszteredményeik alapján kiemelkedően tehetséges amerikai gyermekek az 1920-as években fizikai képességeikben és egészségükben is átlagon felüliek (Shurkin, 1992). Különösen erős elképzelések fúződnek az intelligencia és a mentális egészség viszonyához. Ezek sokszor vékony határvonalat tételeznek fel a kreatív zsenialitás és az elmebaj vagy a melankólia között (Kaufman, 2014; Weismann-Arcache \& Tordjman, 2012). A kognitív epidemiológia - néhány korai vizsgálattól eltekintve (Albee, Lane, \& Reuter, 1964; Lane \& Albee, 1968; Mason, 1956) - módszertani limitációk miatt elsősorban csak a 21. század folyamán tudta először érdemben tesztelni ezeket a hipotéziseket és feltárni az intelligencia és az egészség közötti valódi öszszefüggést. 


\subsection{A kognitív epidemiológiai vizsgálatok módszertana}

A kognitív epidemiológiai vizsgálatok a pszichometriai intelligenciának az egészségi állapottal való összefüggését vizsgálják. Mivel az egészségi állapot romlása - különösen a pszichiátriai betegségek (Kendler, Ohlsson, Keefe, Sundquist, \& Sundquist, 2017; Keyes, Platt, Kaufman, \& McLaughlin, 2017), de esetenként a szomatikus betegségek esetében is - hatással lehet a központi idegrendszer múködésére és ezen keresztül az intelligenciahányadosra, az ok-okozati viszonyok megfelelő feltárása érdekében a kognitív epidemiológiai vizsgálatok jellemzően hosszmetszetiek (longitudinálisak). A kognitív képességek mérése a vizsgálat elején történik, az egészségi állapot felmérése pedig később.

A kognitív epidemiológiai vizsgálatokban számos gyakorlati nehézséget kell megoldani, amelyek speciális vizsgálati elrendezéseket igényelnek:

1. Törekedni kell arra, hogy mind a kognitív képességek kezdeti felmérésekor, mind az egészségi állapot későbbi felmérésekor lehetőleg reprezentatív és torzításmentes legyen a minta. El kell kerülni például azt, hogy az egészségi állapot felméréséből szisztematikusan kimaradjanak a minta időközben megbetegedett résztvevői.

2. Mivel egyes betegségek csak késői életszakaszban alakulnak ki, törekedni kell arra, hogy a minta résztvevőinek utánkövetése hosszú éveken, lehetőleg évtizedeken keresztül történjen. Ideális esetben gyermek- vagy fiatal felnőttkortól időskorig vagy a halál időpontjáig szükséges követni a minta résztvevőit.

3. Mivel számos betegség ritka, kellően nagy elemszámú mintákra van szükség ahhoz, hogy fel tudjuk mérni előfordulásuk gyakoriságának változását a kognitív képességek függvényében.

A fenti problémák miatt a kognitív epidemiológiai vizsgálatok jellemzően születési kohorszok, reprezentativitásra törekvő longitudinális minták vagy teljes populációs minták követésén alapulnak. A születési kohorszok egy adott időszakban, általában egy adott városban született összes gyermek több évtizedes követésén alapulnak. Egy új-zélandi kohorszvizsgálat például a Dunedin városában 1972-1973-ban született összes gyermeket (Koenen és mtsai, 2009), egy brazil vizsgálat pedig a Pelotas városában 1982-ben, 1993-ban és 2004-ben született gyermekeket követi (Santos és mtsai, 2010; Victora és mtsai, 2003). A longitudinális vizsgálatokba jellemzően önkénteseket válogatnak be (a kohorszvizsgálatoknál kevésbé átfogó módon, de többnyire a reprezentativitásra törekedve), akiket utána rendszeresen újra felkeresnek mérések, vizsgálatok céljából. Például az amerikai 1979-es National Longitudinal Study of Youth (NLSY-79) több mint tízezer fős, országosan reprezentatív mintát követ, akik 1979-ben tinédzserek vagy fiatal felnőttek voltak (Herrnstein \& Murray, 2010), a brit E-Risk longitudi- 
nális ikervizsgálat pedig több mint 2000, 1999-ben 5 éves ikergyermeket, akiket országos reprezentativitást biztosítva válogattak be (RichmondRakerd és mtsai, 2019). Sok szempontból a legjobb adatforrások a teljes populációs vizsgálatok, amelyek a születési kohorszokhoz hasonlóan pontszerü, de a teljes népességet lefedő adatfelvételen alapulnak. Ezek közül különösen jó minőségú adatok állnak rendelkezésre Skóciában és a skandináv országokban. Skóciában 1932-ben és 1947-ben az úgynevezett Skót Mentális Felmérések során gyakorlatilag valamennyi akkori 11 évessel egy IQ-tesztet töltettek ki (az összes gyermekkel, aki egy adott napon a kötelező iskolai oktatáson részt vett) (Deary, Whiteman, Starr, Whalley, \& Fox, 2004). A skandináv országokban részletes, több évtizedre visszamenő adatbázisok állnak rendelkezésre a kötelező sorkatonai szolgálat során kitöltött IQ-tesztek eredményéről (Gale, Batty, Tynelius, Deary, \& Rasmussen, 2010; UrferParnas, Lykke Mortensen, Saebye, \& Parnas, 2010). Ez a legjobb adatbázissal rendelkező Svédországban közel 1 millió sorkatona - gyakorlatilag több évtizeden keresztül az összes, az országban született férfi - 18 éves kori IQjának ismeretét jelenti. Mind a három vizsgálati elrendezésre igaz, hogy nem kifejezetten egyetlen kognitív epidemiológiai hipotézis vizsgálatára létrejött, hanem számos egyéb vizsgálatban is sokszor évtizedeken át használt adatbázisokkal dolgozik, amelyekben ezért jellemzően rengeteg adat található a résztvevők egyéb jellemzőiról is. Nem ritka az sem, hogy ugyanabban a vizsgálati mintában bizonyos időközönként újraszámolják az eredményeket, ahogy a résztvevők idősebbek lesznek és egészségügyi élettörténetük előrehalad (Der, Batty, \& Deary, 2009; Wraw, Deary, Gale, \& Der, 2015).

A születésikohorsz- és longitudinális vizsgálatokban többnyire lehetőség van arra, hogy a résztvevőkkel egy későbbi időpontban felvegyék a kapcsolatot, és fizikai vagy mentális egészségükről önkitöltős kérdőívekkel vagy interjúkkal szerezzenek információt. Egy másik, a teljes populációs vizsgálatokban jellemzően egyedüli lehetőség az adatszerzésre, hogy a vizsgálat elején megszerzett személyes adatokat - megfelelő etikai engedély birtokában - összevetik az országos elektronikus betegregiszterekkel. Így a kutatók személyes kapcsolatfelvétel nélkül is adatokat szerezhetnek a vizsgálatban részt vevők egészségügyi élettörténetéről és esetleges halálozásáról, valamint annak okáról. Ennek a módszernek az elónye, hogy akkor is szerezhetó adat egy, a vizsgálat első fázisában részt vett személyről, ha nem kooperálna a vizsgálat későbbi fázisával, vagy adott esetben nincs is már életben. Hátránya, hogy csak azokról az egészséggel kapcsolatos kimenetelekról szerezhetók így adatok, amelyeknek nyoma van az egészségügyi regiszterekben: például egy öngyilkossági kísérletről vagy halálozásról (BNOkódok alapján) igen, viszont a személynek csak kérdőívvel vagy interjúval megismerhető öngyilkossági gondolatairól nem. 
Egy további probléma a kognitív epidemiológiai vizsgálatokban az okokozati viszonyok feltárása. A vizsgálatok longitudinális elrendezése - különösen, ha több évtizedes utánkövetés áll fenn - garantálja, hogy a betegség nem hathat a kiinduláskor mért intelligenciahányadosra. Ez azonban nem jelenti automatikusan azt, hogy szignifikáns összefüggés esetében az intelligenciahányados közvetlen oki hatással van az egészségi állapotra. Elképzelhető, hogy egy, már az intelligenciahányados mérését megelőző ok hat magára az intelligenciahányadosra és a későbbi egészségi állapotra is (mögöttes ok), ahogy az is, hogy az intelligenciahányados hatását egy további tényező közvetíti (mediáció) (1. ábra).

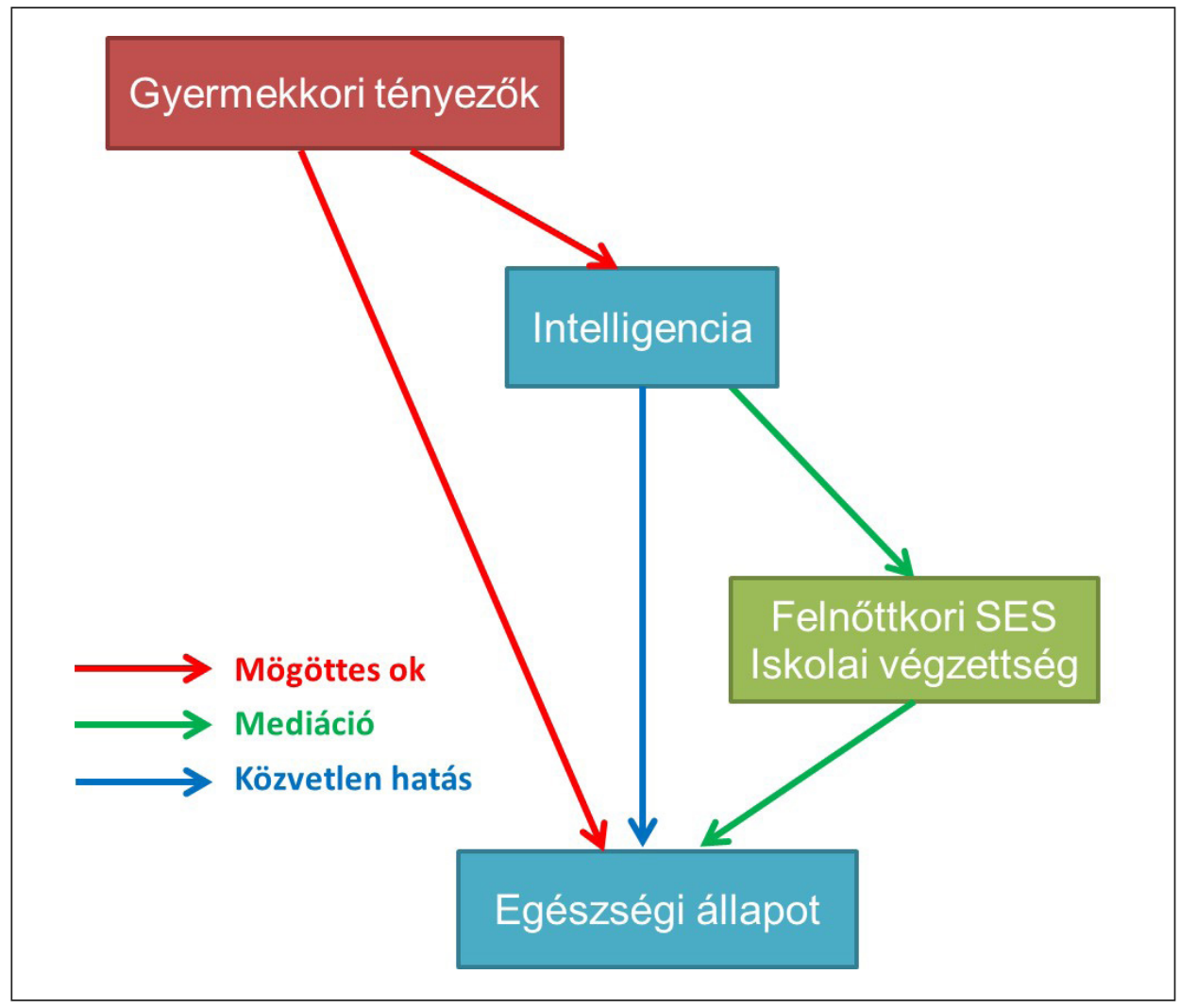

1. ábra. Az intelligencia és az egészségi állapot összefüggésének lehetséges útjai: közvetlen hatás, mögöttes okok miatti összefüggés és közvetítő tényezőkön keresztüli mediáció

Megjegyzés: A mögöttes okoknál és a mediáló tényezőknél megadott változók csak példák. Mögöttes ok lehet bármi, ami időben megelőzi mind az intelligencia, mind az egészségi állapot mérését, és hatással van rájuk, mediáló tényező pedig bármi olyan lehet, ami az intelligencia következménye és a későbbi egészségi állapot oka. SES = szocioökonómiai státusz. 
Elképzelhetó például, hogy a gyermekkori rossz szociális helyzet alultápláltsághoz vezet, ami a fiatal felnőttkori IQ mérésekor alacsonyabb intelligenciahányadost, később pedig rosszabb egészségi állapotot és korábbi halálozást okoz (mögöttes ok). Elképzelhetó az is, hogy a magasabb intelligenciahányadossal rendelkezők átlagosan magasabb presztízsú, jobban fizető munkahelyeken dolgoznak (Strenze, 2007, 2015), ami anyagi és praktikus okokból is egészségesebb életmódot és jobb egészség-magatartást tesz lehetővé (mediáció). A mögöttes okokra és a mediációra vonatkozó hipotézisek tesztelhetőek, ha a feltételezett mögöttes okokról és mediáló változókról rendelkezünk adatokkal és a használt statisztikai modellekben kovariánsként használjuk azokat.

A tipikus kognitív epidemiológiai vizsgálat többszörös idősoros regreszsziós modelleket (például Cox-regressziót) alkalmaz az intelligenciaszintnek a betegség megjelenésének (binárisan kódolt) kockázatára gyakorolt hatásának becslésére. Ezek a modellek jellemzően kockázati hányadosként (hazard ratio, HR), ritkábban esélyhányadosként (odds ratio, OR) fejezik ki az intelligenciaszint hatásméretét, általában 15 IQ-pontonként. A 0,7-es kockázati hányados például azt fejezi ki, hogy egy adott idópontig 15 IQ-pontonként 30\%-kal csökken egy egészségi probléma (például pszichiátriai betegfelvétel, daganatos betegfelvétel vagy halálozás) bekövetkezésének esélye. Azaz egy 115-ös IQ-pontszámmal rendelkező személy egy 100-as IQ-pontszámmal rendelkező személy kockázatának csak 70\%-ával rendelkezik. Egyes vizsgálatok ritkábban folytonos kimeneti változókat (például egy depresszióra vonatkozó tünetbecslő skála pontszámát) használják korrelációs vagy regressziós elemzésekben, vagy egyszerúen a vizsgálat végéig megbetegedett és egészségesen maradt vizsgálati személyek premorbid, a vizsgálat elején mért IQ-ját hasonlítják össze.

Valamennyi többszörös regressziós modellben lehetőség van potenciális mögöttes okok vagy mediáló tényezők hatásának korrekciójára és az IQ-ra vonatkozó korrigált, a közvetlen hatást kifejező kockázati hányados kiszámítására. Ha például egy, az IQ és a teljes halálozási kockázat kapcsolatára vonatkozó vizsgálatban rendelkezünk adatokkal a résztvevők gyerekkori és felnőttkori szocioökonómiai státuszáról és ezeket kovariánsként használjuk, akkor az IQ-ra vonatkozó korrigált kockázati hányados gyakorlatilag azt fejezi ki, hogy azonos gyerekkori és felnőttkori szociális státuszú személyek között mennyi volna 15 IQ-pontnyi különbség hatása a halálozási kockázatra. A legtöbb kognitív epidemiológiai vizsgálat részletes adatokkal rendelkezik potenciális mögöttes okokról és mediáló tényezőkről, és ezek hatását korrigálja. Ez a módszer - erősségei ellenére - természetesen csak azoknak a tényezőknek a közvetítő hatását képes mérni, amelyekről rendelkezünk adatokkal, a közvetítő tényezők mérési hibája miatt pedig a valósnál gyengébb mediáló hatást láthatunk. Például tételezzük fel, hogy a gyermekkori 
IQ hatása a felnőttkori egészségre nem közvetlen, hanem teljes egészében a felnőttkori jövedelem közvetíti! Ebben az esetben, ha csak az iskolai végzettségről van adatunk, akkor az IQ várhatóan jelentős közvetlen hatását fogjuk mérni, amit az iskolai végzettség csak annyiban mediál, amennyiben összefügg a jövedelemmel. Ha van adatunk a jövedelemról, de ez pontatlan (például mert a vizsgálatban részt vevők nem nyilatkoznak teljesen őszintén a jövedelmükről), akkor a jövedelem mediáló hatása miatt várhatóan közvetlen IQ-hatást is mérni fogunk. A legtöbb vizsgálat ugyanakkor nagyszámú és pontosan mérhető/operacionalizálható mediáló tényező hatását is mérni tudja.

A kognitív epidemiológiai vizsgálatok eredményeit torzíthatja, ha a független változó (jelen esetben az intelligencia), vagy valamilyen korrelátuma (például az iskolai végzettség) a betegségek előfordulása mellett az orvoshoz fordulás valószínúségére is hatással van. Ebben az esetben elképzelhető, hogy bár a kevésbé intelligens vizsgálati személyek gyakrabban betegszenek meg, mivel ritkábban fordulnak orvoshoz, az összefüggés rejtve marad. Ahogy hamarosan látni fogjuk, ennek ellenére gyakorlatilag az összes szomatikus és mentális betegséget ritkábban találjuk meg a magasabb intelligenciahányadossal rendelkezőknél. Az orvoshoz fordulás torzító hatása miatt azonban az összefüggés még a mértnél is erősebb lehet.

\section{Pszichiátriai betegségek}

A pszichiátriai betegségek kognitív epidemiológiai vizsgálatát megkönnyíti, hogy viszonylag fiatal életkorban megjelennek, ezért esetükben nincs szükség több évtizedes utánkövetésre. Nehézséget jelent azonban, hogy egyes zavarok (például a schizophrenia vagy a poszttraumás stressz-zavar) viszonylag ritkák, ezért kifejezetten nagy mintára van szükség a pontos mérésekhez.

A pszichiátriai betegségekkel kapcsolatos kognitív epidemiológiai eredmények elsősorban kétfajta adatforráson alapulnak: 1. nagyon nagy elemszámú, de viszonylag rövid utánkövetésú sorkatonai vagy teljes populációs adatbázisok elemzésén, amelyekben betegregiszterekből van adat a kezelt pszichiátriai betegségekról; 2. legfeljebb néhány ezer fős longitudinális vizsgálatokon, amelyekben sokszor kérdőívekkel is felmérik a résztvevők mentális egészségét, így lehetővé téve a szubklinikai szintú vagy betegfelvételhez nem vezető pszichiátriai tünetek mérését is.

A legnagyobb vizsgálatokat - egyéb zavarokra is kiterjedően - az 1. táblázat foglalja össze. Gyakorlatilag valamennyi pszichiátriai betegségre igaz, hogy a magasabb premorbid intelligenciaszint a betegség kialakulásának/ megjelenésének alacsonyabb kockázatával jár együtt. A kockázatcsökkenés 
jellemzően kifejezetten jelentős: egy több mint 1 millió fős svéd sorkatonai vizsgálat (Gale és mtsai, 2010) például 15 IQ-pontonként a depresszió és a szorongásos zavarok kockázatának egyharmados, a függőségek és személyiségzavarok kockázatának pedig 40\%-ot meghaladó mértékú redukcióját találta. Ugyanebben a mintában az öngyilkossági kísérletek és halálozások - más vizsgálatokkal összhangban - 15 IQ-pontonként 10-30\%-kal ritkábbak voltak (Batty és mtsai, 2010). Ezek a több mint 1 millió résztvevő adataiból származó eredmények csak a pszichiátriai betegfelvételekre vonatkoznak, de hasonló eredmények születtek kérdőíves vizsgálatokból is. Gale, Hatch, Batty és Deary (2009) például két, egyenként több mint 6000 fős brit longitudinális minta elemzésénél szignifikáns negatív irányú korrelációt talált a 10 vagy 11 évesen mért IQ és a 30 vagy 33 évesen felvett pszichológiai distressz-kérdőív (Malaise Inventory) pontszáma között $(r=-0,11$ és $r=-0,18)$. Wraw és munkatársai (2016) ehhez hasonlóan negatív irányú, szignifikáns összefüggést találtak az amerikai National Longitudinal Study of Youth (NLSY-79) közel 6000 fós résztvevőjénél a fiatal felnőttkorban felvett IQ és az 50 évesen felvett Health Survey mentális betegségekre vonatkozó részpontszáma $(r=-0,03)$, a Center for Epidemiological Studies Depression Scale pontszáma $(r=-0,14)$ és egy alvási nehézségekre vonatkozó kérdőív pontszáma $(r=-0,13)$ között. Hasonló eredmények születtek az aberdeeni 1921-es születési kohorsznál (tünetmérés 78,2 évesen a Hospital Anxiety and Depression Scale skálával, $N=88, r=-0,21$ ) (Bain és mtsai, 2003) és a brit 1946-os születési kohorsznál (tünetmérés 53 évesen, a General Health Questionnaire skálával, $N=918$ [férfiak], $\beta=-0,003 ; N=957$ [nők], $\beta=-0,17$ ) is (Hatch és mtsai, 2007).

Ezekhez a trendekhez gyakorlatilag egyedüliként a brit Avon Longitudinal Study (ALSPAC) tinédzsereken és fiatal felnőtteken végzett kérdőíves vizsgálatai nem illeszkednek. Ebben a reprezentatív vizsgálatban, ami az Avon városában 1991-1992-ben született gyermekek utánkövetésén alapul, pozitív összefüggést találtak a 8 éves korban felvett IQ, valamint a később felvett Hypomania Checklist mániás tüneteket mérő kérdőív eredménye (Smith és mtsai, 2015), a depressziós tüneteket mérő Short Mood and Feelings Questionnaire kérdőív eredménye (Glaser és mtsai, 2011), valamint az öngyilkossági gondolatok, tervek és az önkárosító magatartás között (Chang és mtsai, 2014). Csak ez utóbbi változóval kapcsolatban történtek egyéb, fiatalokon végzett vizsgálatok: ezek közül sem a brit E-Risk kohorszban (Richmond-Rakerd és mtsai, 2019), sem az ausztrál Mater University Study of Pregnancy kohorszban (Alati, Gunnell, Najman, Williams, \& Lawlor, 2009) nem replikálódik a magasabb intelligenciájú fiatalok magasabb kockázata az önkárosító viselkedésre.

A legtöbb vizsgálat - beleértve a betegregisztereken alapulókat is - rendelkezett adatokkal potenciális mögöttes okokról és mediáló tényezőkről, például a résztvevók gyerekkori vagy felnőttkori szocioökonómiai státuszá- 
ról vagy egészség-magatartásáról. Bár ezek pontos listája az egyes vizsgálatok között nagyon heterogén, az eredményekben közös, hogy ezeknek a tényezőknek a statisztikai korrekciója többnyire csak nagyon keveset módosít a premorbid IQ és a betegségkockázat kapcsolatán.

Kendler és munkatársai (2017) több mint egymillió, 1972 és 1990 között született svéd személy és elektronikus regiszterek alapján azonosított családtagjaik premorbid kognitív teljesítményét (ezt 16 évesen írt standardizált iskolai tesztek eredményeiból vagy a szülők esetében az iskolai végzettségből becsülték) kötötték össze későbbi pszichiátriai betegfelvételeikkel. A vizsgálat tanulsága, hogy nemcsak az egyéni kognitív teljesítmény, hanem annak a családtagokhoz viszonyított relatív szintje is jelentős korrelátuma a későbbi pszichiátriai betegségeknek (2. ábra). A szerzők négy jellemzó mintázatot azonosítottak: 1. az autizmus, a schizophrenia és részben a bipoláris zavar miatt egészségügyi kezelésben részesültek alacsony, családtagjaik viszont magas intelligenciaszinttel rendelkeztek; 2 . az internalizáló zavarok (major depressziós zavar vagy szorongásos zavar) miatt kezeltek alacsony intelligenciaszinttel rendelkeztek, családtagjaik intelligenciaszintjével nem volt összefüggés; 3 . az alkohol- vagy drogproblémák miatt kezeltek családtagjaikkal együtt jellemzően alacsony intelligenciaszinttel rendelkeztek; 4. az evészavarok miatt kezeltek családtagjaikkal együtt jellemzően magas intelligenciaszinttel rendelkeztek.

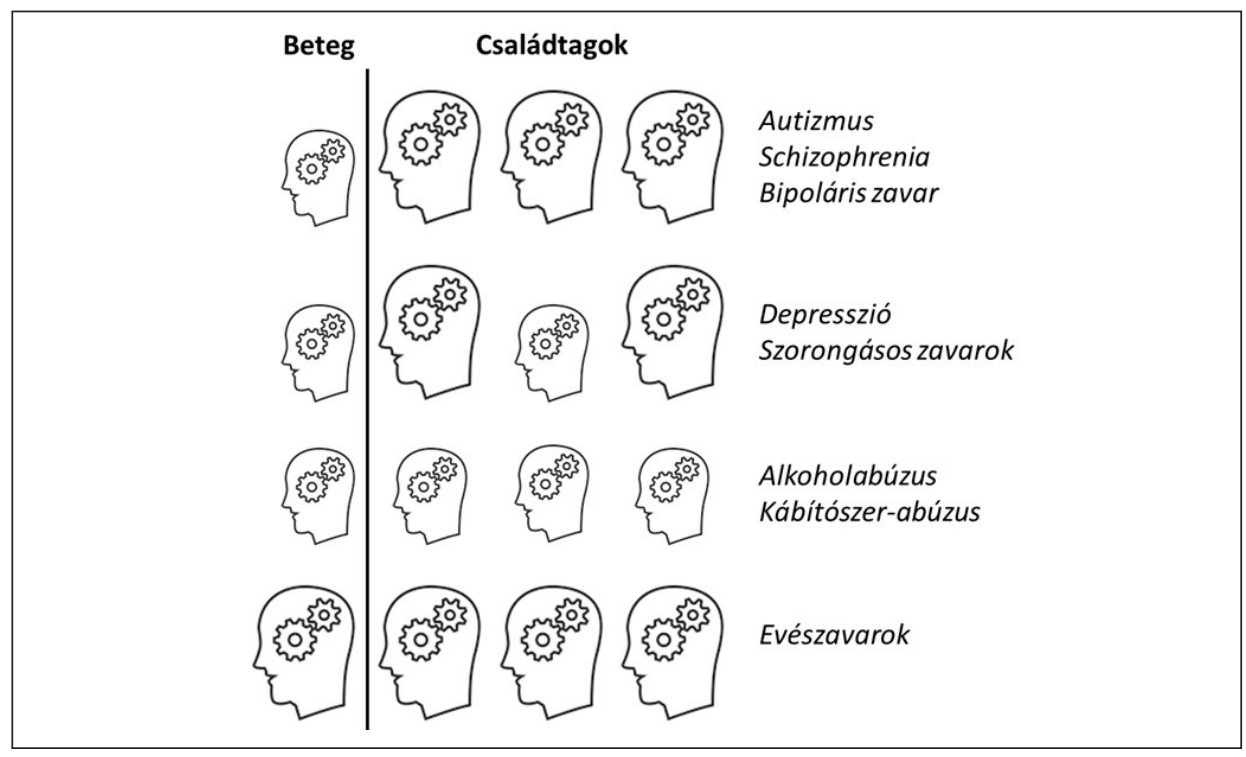

2. ábra. A különböző pszichiátriai problémáktól szenvedő személyek és családtagjaik (három ábrával szimbolizálva) jellemző intelligenciaszintje Kendler és munkatársai (2017) eredményei alapján

Megjegyzés: A kicsi sematikus rajzok alacsony, a nagyok magas intelligenciaszintet szimbolizálnak. 


\begin{tabular}{|c|c|c|c|c|}
\hline 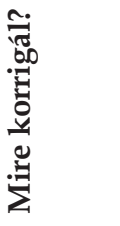 & & 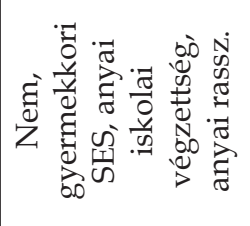 & & 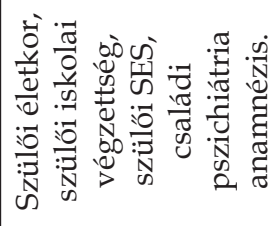 \\
\hline 党 & $\begin{array}{l}9 \\
0 \\
11 \\
0\end{array}$ & $\begin{array}{l}03 \\
0 \\
0 \\
11 \\
1 \\
0 \\
0\end{array}$ & 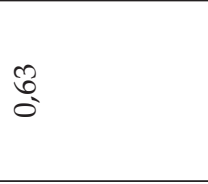 & $\begin{array}{l}\infty \\
0 \\
0 \\
0\end{array}$ \\
\hline 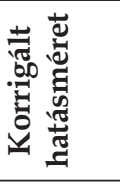 & । & $\begin{array}{l}\infty \\
0 \\
0 \\
11 \\
0 \\
0 \\
0\end{array}$ & I & $\stackrel{\Omega}{\widehat{N}}$ \\
\hline 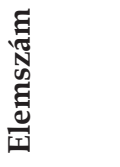 & $\begin{array}{l}0 \\
\stackrel{1}{\circ} \\
\stackrel{0}{1}\end{array}$ & $\begin{array}{l}\text { के } \\
\text { o }\end{array}$ & 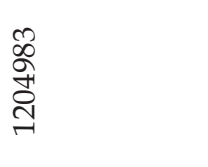 & $\begin{array}{l}\stackrel{R}{1} \\
\stackrel{2}{0} \\
\stackrel{10}{\sim}\end{array}$ \\
\hline 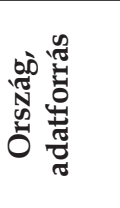 & 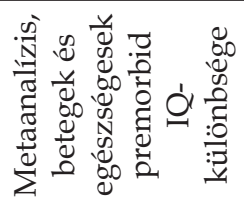 & 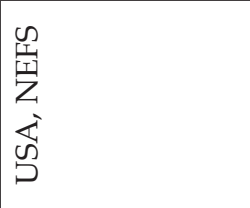 & 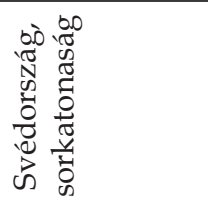 & 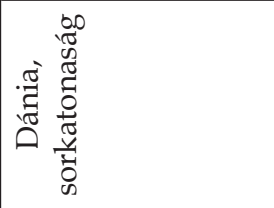 \\
\hline 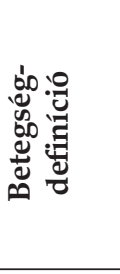 & 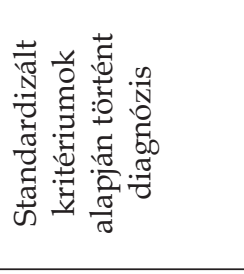 & 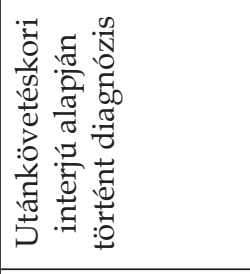 & 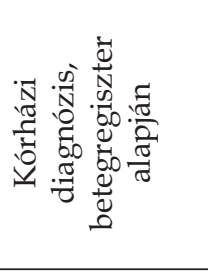 & 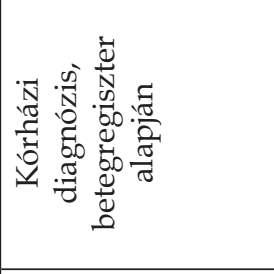 \\
\hline 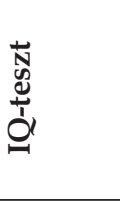 & 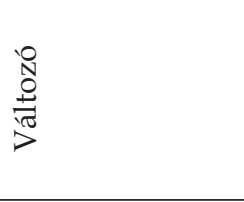 & 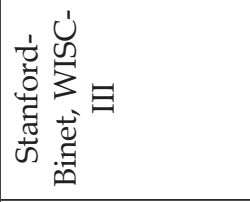 & 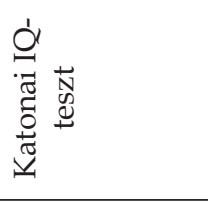 & 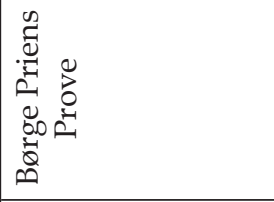 \\
\hline 胥 & 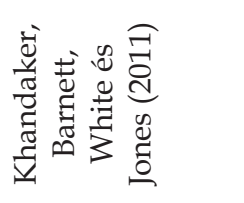 & 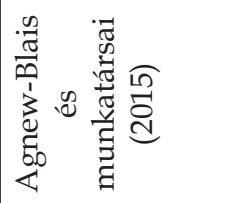 & 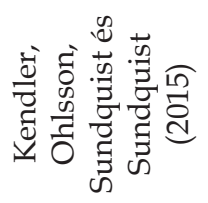 & 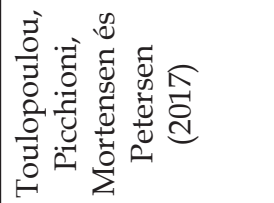 \\
\hline 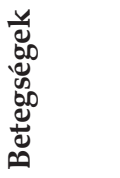 & \multicolumn{4}{|c|}{ Schizophrenia } \\
\hline
\end{tabular}




\begin{tabular}{|c|c|c|c|c|}
\hline 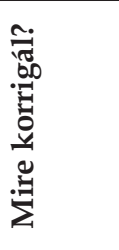 & & 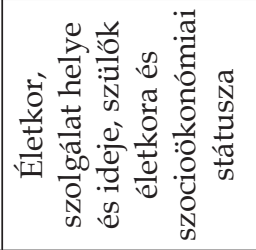 & & \\
\hline 党 & $\begin{array}{l}0 \\
0 \\
0 \\
11 \\
0\end{array}$ & ڤ̊ & $\begin{array}{l}\text { రై } \\
\text { ठ }\end{array}$ & 会 \\
\hline 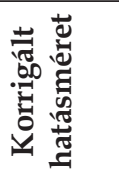 & 1 & ڤ̊ & 1 & 1 \\
\hline 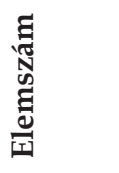 & $\begin{array}{l}12 \\
\stackrel{1}{0} \\
\text { N }\end{array}$ & 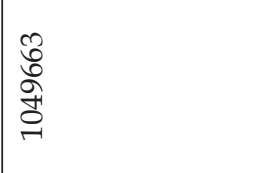 & $\begin{array}{l}\text { बें } \\
\text { శ్ర }\end{array}$ & 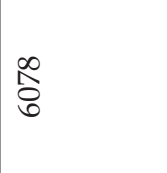 \\
\hline 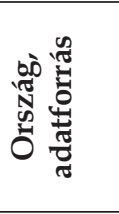 & 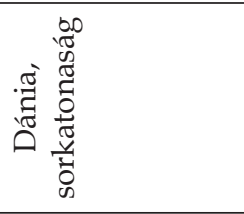 & 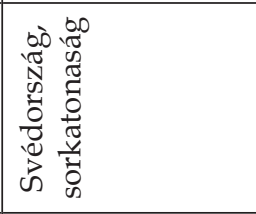 & 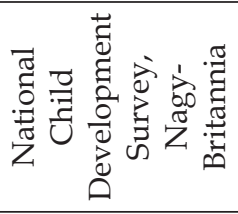 & 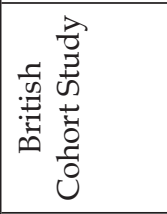 \\
\hline 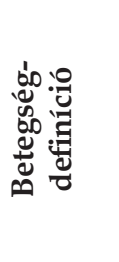 & 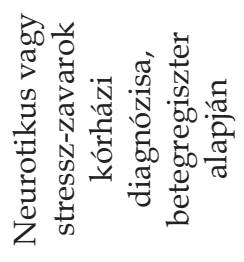 & 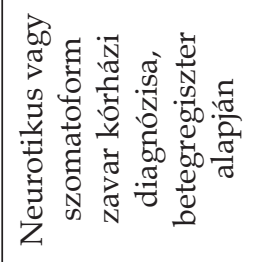 & 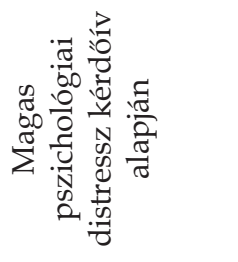 & 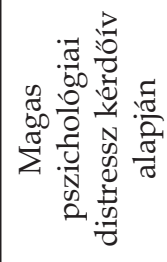 \\
\hline 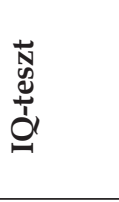 & 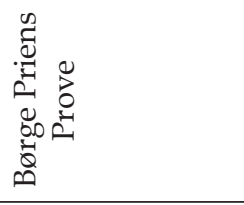 & 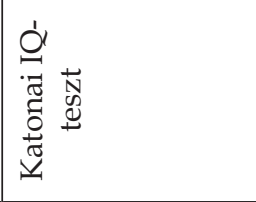 & 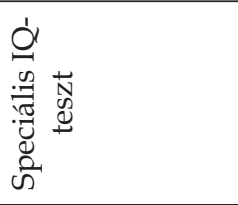 & 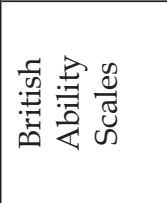 \\
\hline 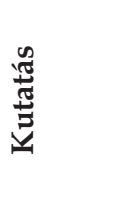 & 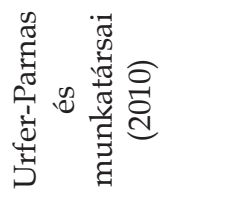 & 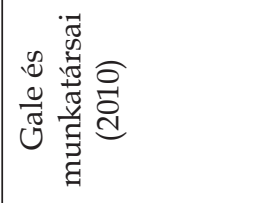 & 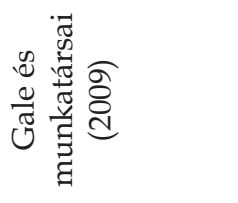 & \\
\hline 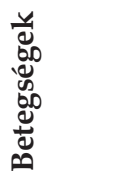 & \multicolumn{4}{|c|}{ Szorongásos zavarok } \\
\hline
\end{tabular}




\begin{tabular}{|c|c|c|c|c|c|}
\hline 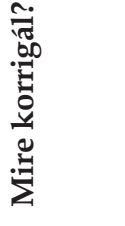 & 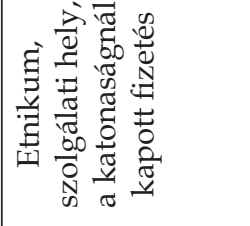 & 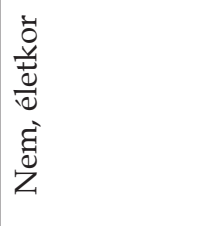 & 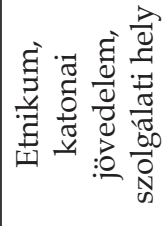 & 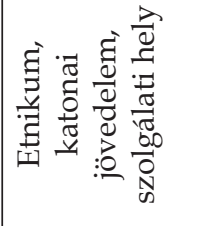 & 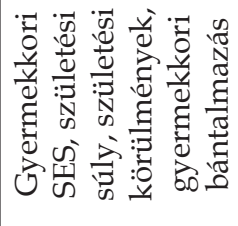 \\
\hline 密芯茪 & $\begin{array}{l}\infty \\
\infty \\
0\end{array}$ & 1 & 点 & $\begin{array}{l}\infty \\
\infty \\
0 \\
0\end{array}$ & $\begin{array}{l}5 \\
\infty \\
0 \\
11 \\
\simeq 1 \\
0\end{array}$ \\
\hline 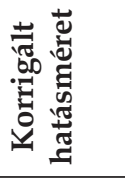 & $\begin{array}{l}0 \\
\infty \\
0 \\
0\end{array}$ & 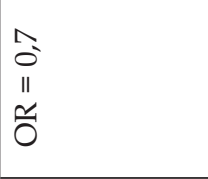 & 足 & 金 & $\begin{array}{l}\hat{0} \\
\text { II } \\
\tilde{0} \\
0\end{array}$ \\
\hline 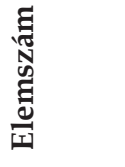 & $\begin{array}{l}\infty \\
\stackrel{\infty}{n} \\
\infty\end{array}$ & $\hat{\overbrace{}}$ & 总 & $\begin{array}{l}\infty \\
\stackrel{2}{n} \\
\infty\end{array}$ & $\hat{\overbrace{}}$ \\
\hline 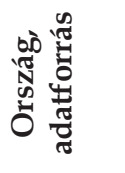 & 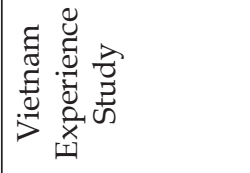 & 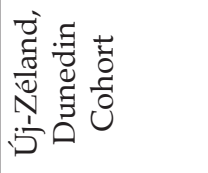 & 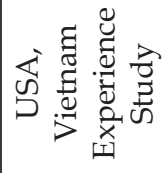 & 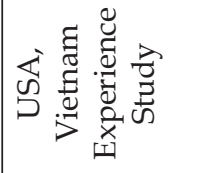 & 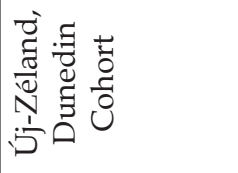 \\
\hline 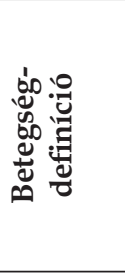 & 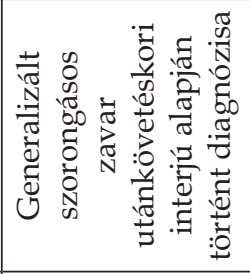 & 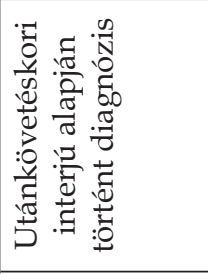 & 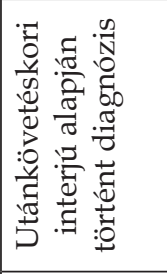 & 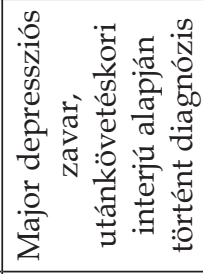 & 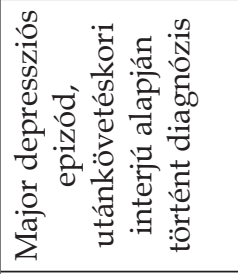 \\
\hline 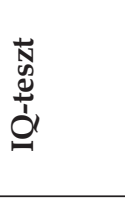 & 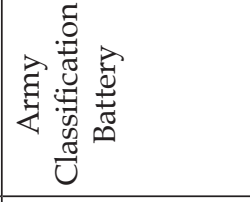 & 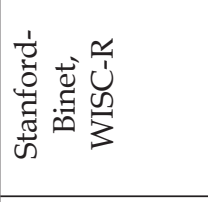 & 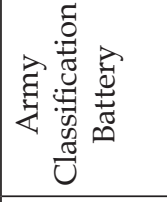 & 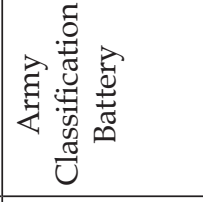 & $\begin{array}{l}\frac{\pi}{4} \\
0 \\
01 \\
3\end{array}$ \\
\hline 胥 & 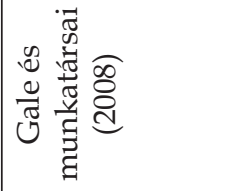 & 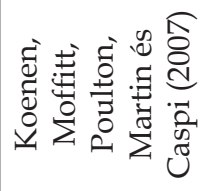 & 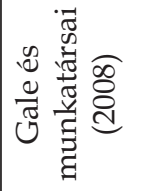 & 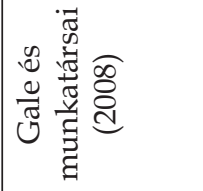 & 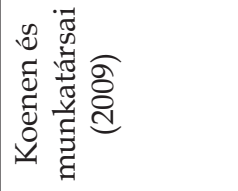 \\
\hline 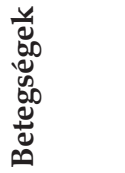 & $\begin{array}{c}\text { Szorongásos } \\
\text { zavarok }\end{array}$ & \multicolumn{2}{|c|}{$\begin{array}{l}\text { Poszttraumás } \\
\text { stressz-zavar }\end{array}$} & \multicolumn{2}{|c|}{ Depresszió } \\
\hline
\end{tabular}




\begin{tabular}{|c|c|c|c|c|c|}
\hline 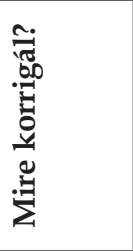 & & 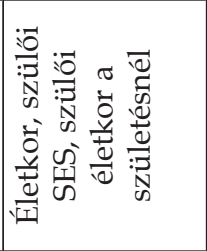 & 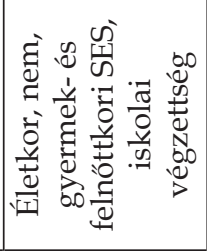 & 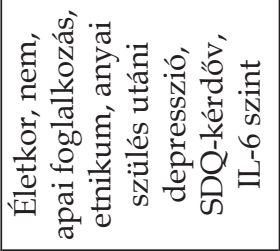 & 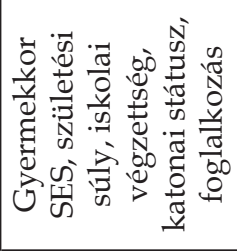 \\
\hline 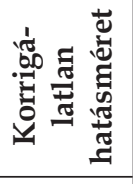 & 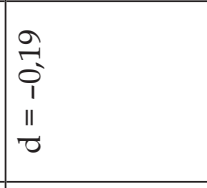 & $\stackrel{8}{0}$ & 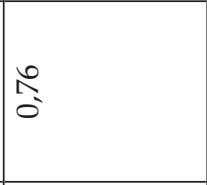 & $\stackrel{R}{\stackrel{R}{O}}$ & $\mid \begin{array}{l}\infty \\
0 \\
0\end{array}$ \\
\hline 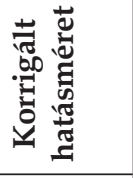 & 1 & 會 & ò & $\infty$ & 点 \\
\hline 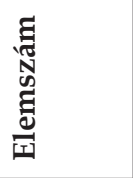 & 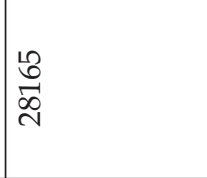 & 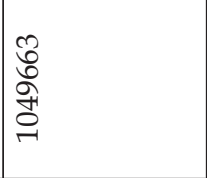 & 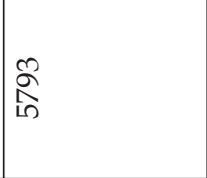 & مू & శ్ \\
\hline 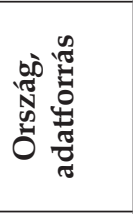 & 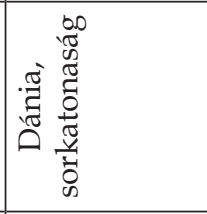 & 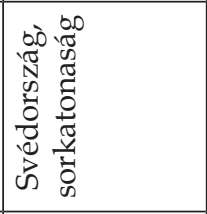 & 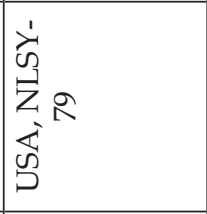 & 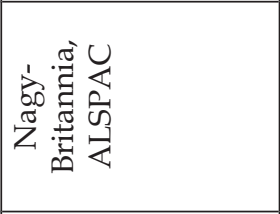 & 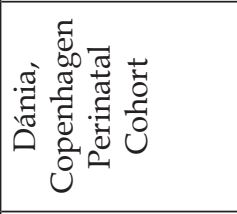 \\
\hline 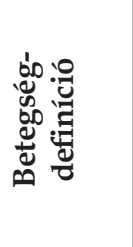 & 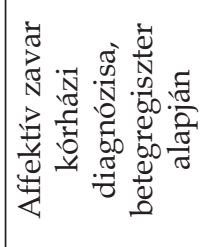 & 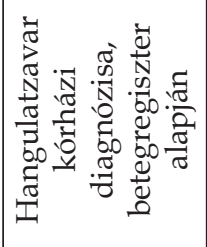 & 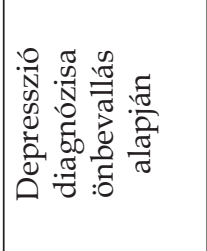 & 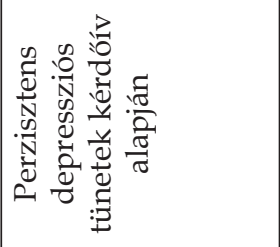 & 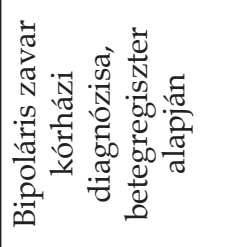 \\
\hline 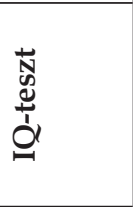 & 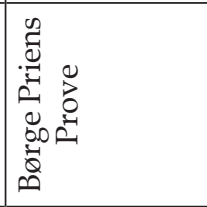 & 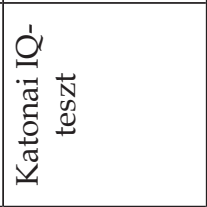 & 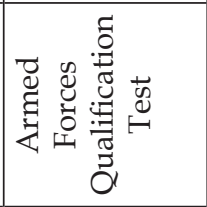 & $\begin{array}{l}1 \\
\vdots \\
0 \\
0 \\
3 \\
3\end{array}$ & 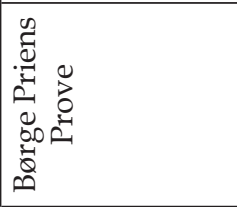 \\
\hline 总 & 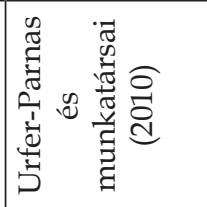 & 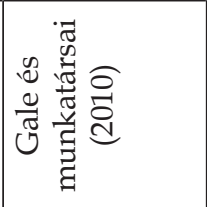 & 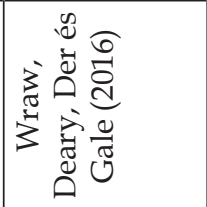 & 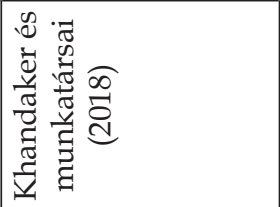 & 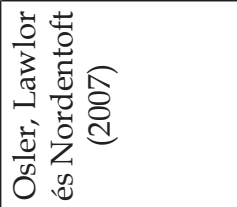 \\
\hline 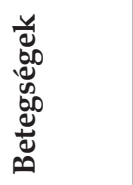 & \multicolumn{4}{|c|}{ Depresszió } & $\begin{array}{l}\text { Bipoláris } \\
\text { zavar }\end{array}$ \\
\hline
\end{tabular}




\begin{tabular}{|c|c|c|c|c|}
\hline 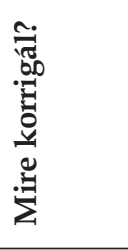 & 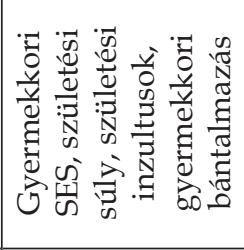 & 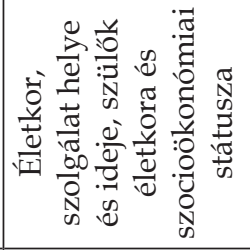 & & \\
\hline 空 & $\begin{array}{l}0 \\
-1 \\
11 \\
11 \\
0 \\
0\end{array}$ & مू مू & $\begin{array}{l}18 \\
0 \\
1 \\
11 \\
11 \\
0\end{array}$ & $\begin{array}{l}2 \\
0 \\
1 \\
11 \\
0\end{array}$ \\
\hline 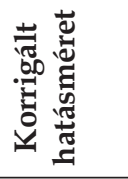 & \begin{tabular}{l}
\multicolumn{1}{c}{} \\
11 \\
11 \\
2 \\
0
\end{tabular} & 1 & 1 & 1 \\
\hline 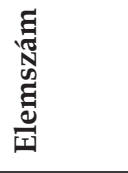 & 命 & $\begin{array}{l}1 \\
0 \\
0 \\
0 \\
0 \\
0\end{array}$ & $\begin{array}{l}\text { के } \\
\text { ले }\end{array}$ & $\begin{array}{l}\text { ने } \\
\text { 户े }\end{array}$ \\
\hline . & 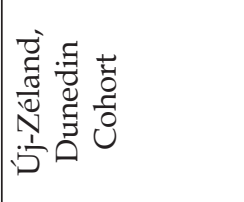 & 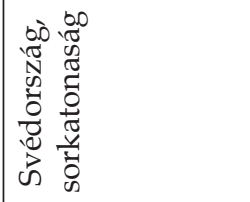 & 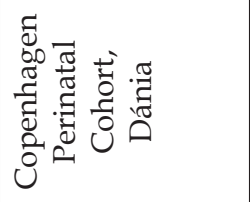 & 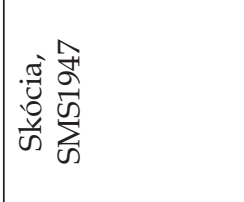 \\
\hline 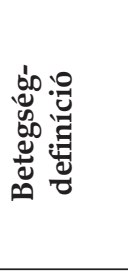 & 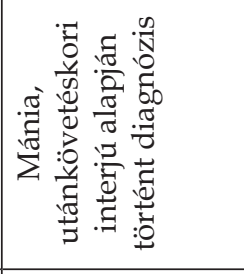 & 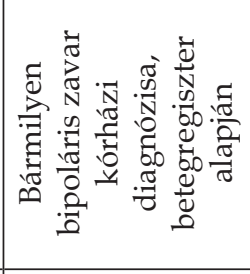 & 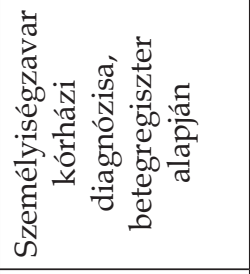 & 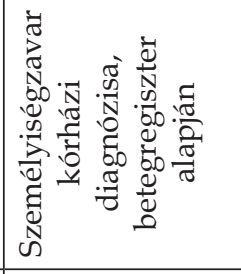 \\
\hline 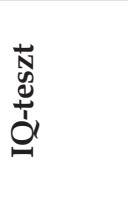 & $\begin{array}{l}\frac{1}{1} \\
0 \\
0 \\
3\end{array}$ & 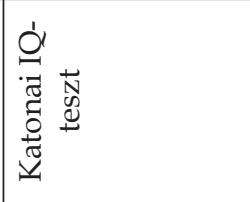 & 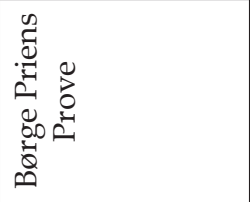 & 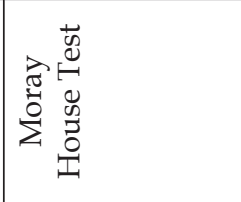 \\
\hline 胥 & 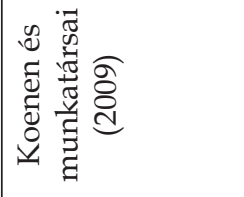 & 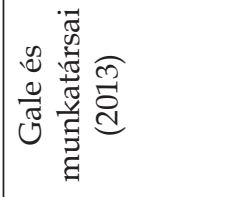 & 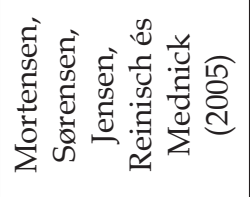 & 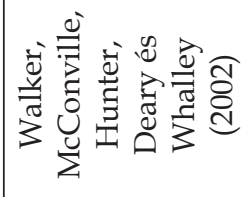 \\
\hline 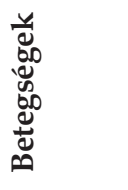 & \multicolumn{2}{|c|}{ Bipoláris zavar } & \multicolumn{2}{|c|}{ Személyiségzavarok } \\
\hline
\end{tabular}




\begin{tabular}{|c|c|c|c|c|}
\hline 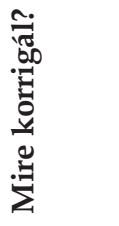 & & 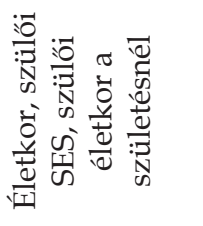 & 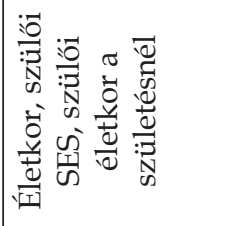 & 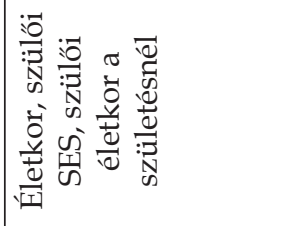 \\
\hline 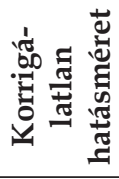 & $\begin{array}{l}18 \\
0 \\
0 \\
11 \\
0\end{array}$ & 命 & ڤ̂ & 望 \\
\hline 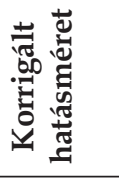 & 1 & 응 & $\begin{array}{l}\infty \\
1 \\
0 \\
0\end{array}$ & $\begin{array}{l}12 \\
\text { L } \\
0\end{array}$ \\
\hline 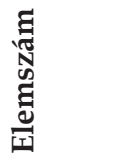 & $\begin{array}{l}\qquad 0 \\
\stackrel{0}{0} \\
\stackrel{\sim}{N}\end{array}$ & 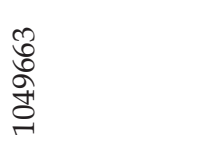 & 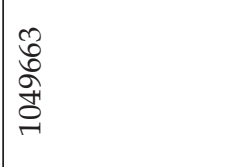 & \begin{tabular}{l}
3 \\
0 \\
0 \\
\multirow{2}{0}{} \\
0
\end{tabular} \\
\hline 宽 & 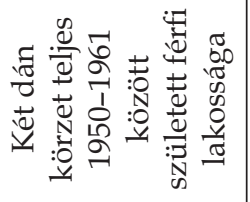 & 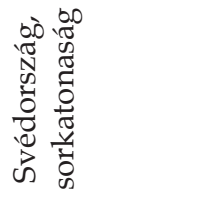 & 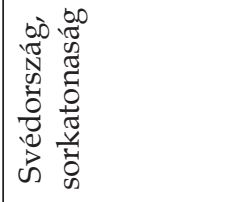 & 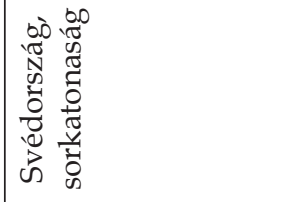 \\
\hline 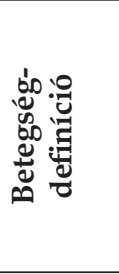 & 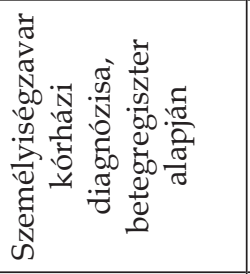 & 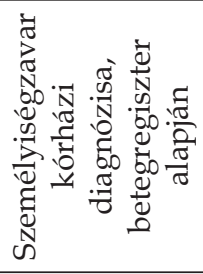 & 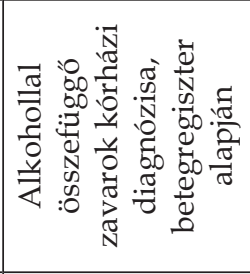 & 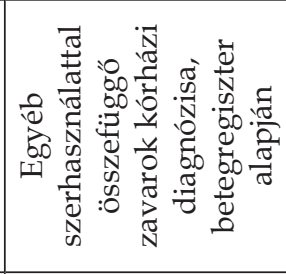 \\
\hline 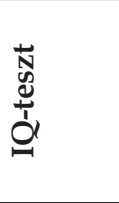 & 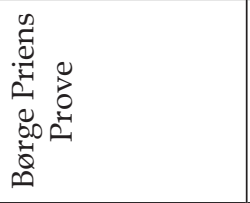 & 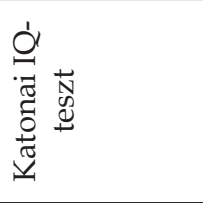 & 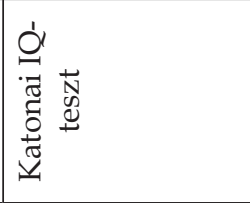 & \\
\hline 忢 & 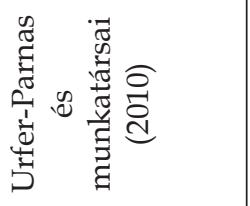 & 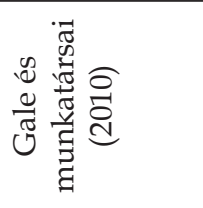 & 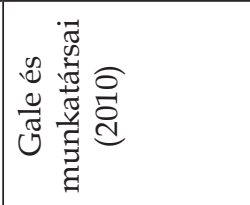 & \\
\hline 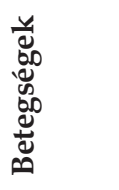 & \multicolumn{2}{|c|}{ Személyiségzavarok } & \multicolumn{2}{|c|}{ Függóségek } \\
\hline
\end{tabular}




\begin{tabular}{|c|c|c|c|c|}
\hline 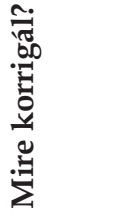 & 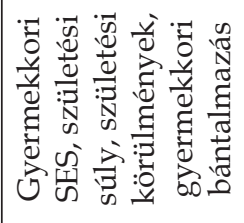 & 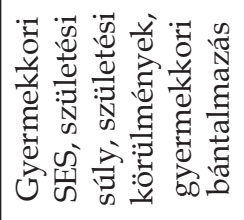 & 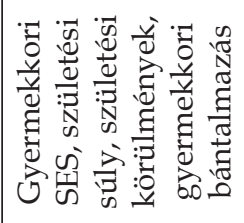 & \\
\hline 空 & \begin{tabular}{l}
$\infty$ \\
\multirow{0}{0}{} \\
0
\end{tabular} & $\begin{array}{l}1 \\
\infty \\
0 \\
0\end{array}$ & 疍 & $\begin{array}{c}\infty \\
\infty \\
0 \\
1 \\
11 \\
0\end{array}$ \\
\hline 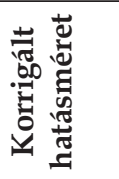 & $\sigma$ & $\underset{\mathrm{O}}{\mathrm{O}}$ & $\stackrel{g}{-}$ & 1 \\
\hline 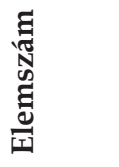 & ळิ & 㐱 & 㐱 & $\begin{array}{l}\text { के } \\
\text { }\end{array}$ \\
\hline 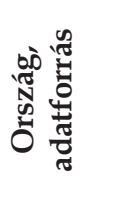 & 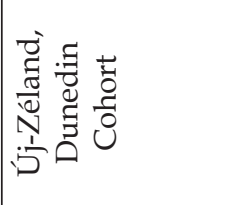 & 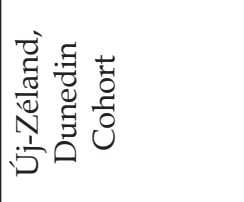 & 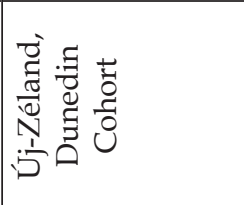 & 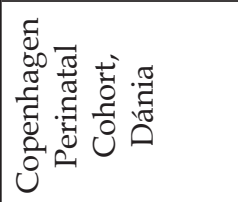 \\
\hline 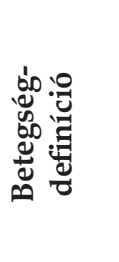 & 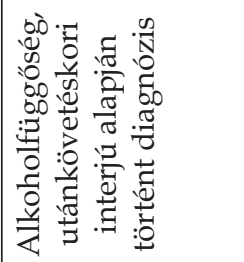 & 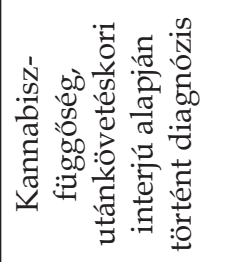 & 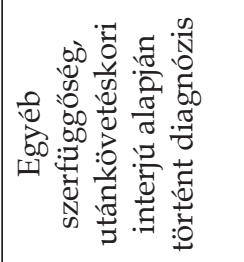 & 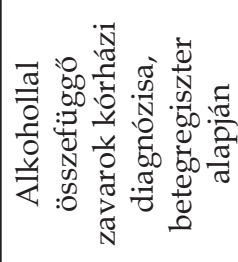 \\
\hline 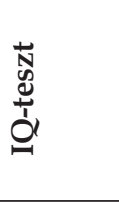 & $\begin{array}{l}2 \\
u \\
0 \\
0 \\
3\end{array}$ & & & 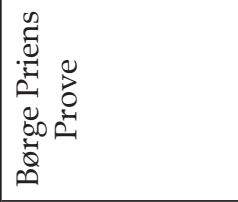 \\
\hline 胥 & 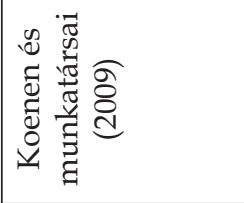 & & & 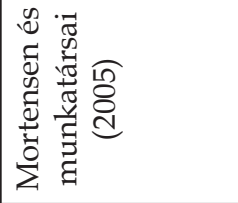 \\
\hline 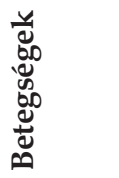 & \multicolumn{4}{|c|}{ Függőségek } \\
\hline
\end{tabular}




\begin{tabular}{|c|c|c|c|c|c|}
\hline 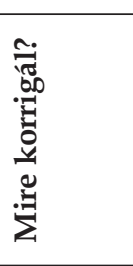 & & & 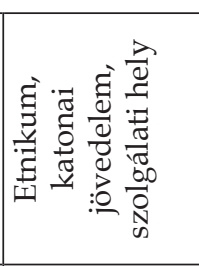 & $\begin{array}{l}\varepsilon \\
\ddot{z}\end{array}$ & 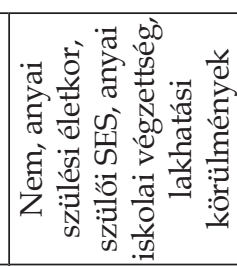 \\
\hline 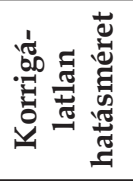 & $\begin{array}{l}0 \\
0 \\
1 \\
11 \\
0\end{array}$ & $\begin{array}{l}8 \\
0 \\
0 \\
11 \\
11 \\
0\end{array}$ & $\infty_{0}^{\infty}$ & 1 & $\underset{-}{\stackrel{8}{二}}$ \\
\hline 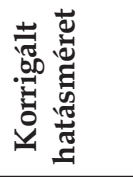 & 1 & 1 & 战 & g. & $\underset{ت}{\stackrel{A}{二}}$ \\
\hline 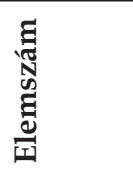 & $\begin{array}{l}\text { के } \\
\text { के }\end{array}$ & $\begin{array}{l}2 \\
\overline{7}\end{array}$ & $\begin{array}{l}\infty \\
\stackrel{\infty}{\Lambda} \\
\infty\end{array}$ & $\underset{F}{F}$ & 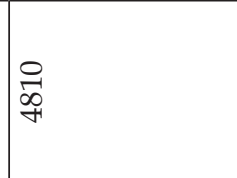 \\
\hline 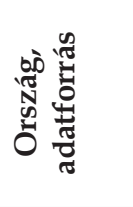 & 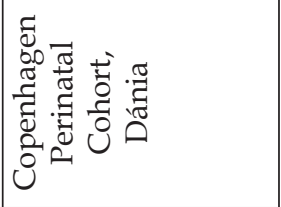 & 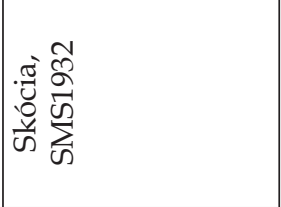 & 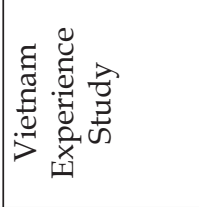 & 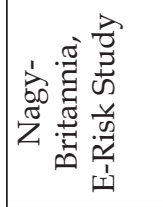 & 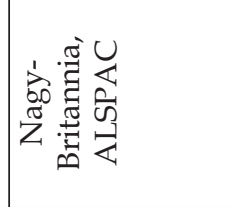 \\
\hline 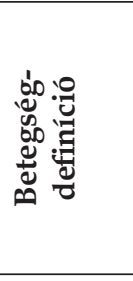 & 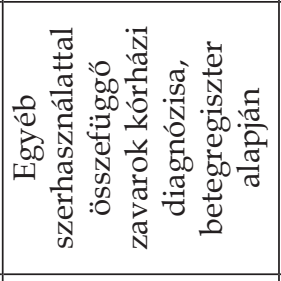 & 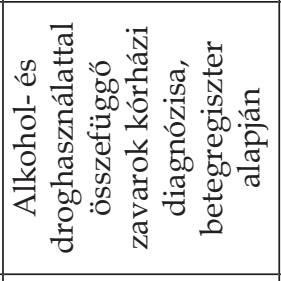 & 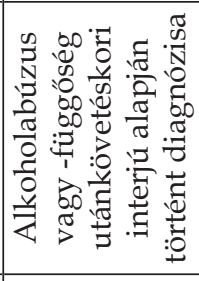 & 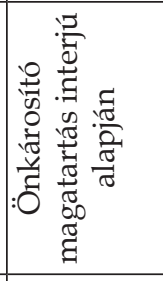 & 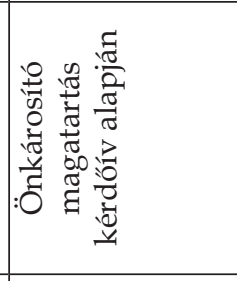 \\
\hline 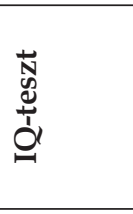 & & 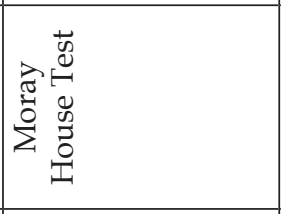 & 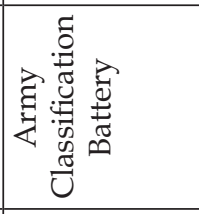 & $\begin{array}{l}\frac{c}{y} \\
w \\
\frac{1}{n} \\
3 \\
3\end{array}$ & 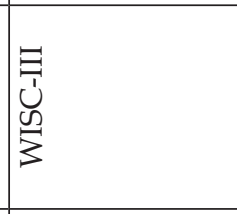 \\
\hline 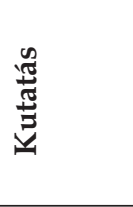 & & 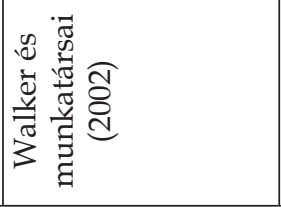 & 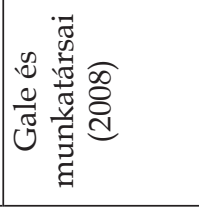 & 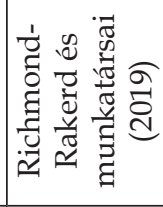 & 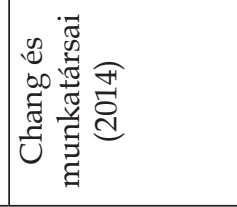 \\
\hline 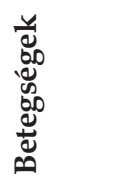 & & \multicolumn{2}{|l|}{ Függőségek } & \multicolumn{2}{|c|}{ Önkárosító magatartás } \\
\hline
\end{tabular}




\begin{tabular}{|c|c|c|c|c|}
\hline 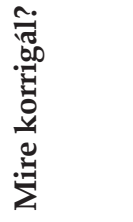 & 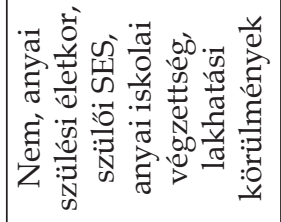 & 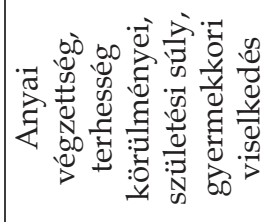 & 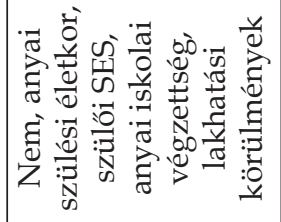 & 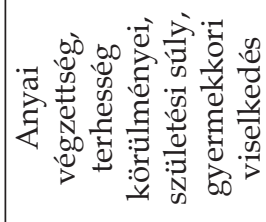 \\
\hline 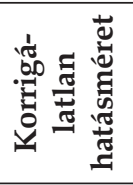 & $\stackrel{\overparen{\Xi}}{-}$ & 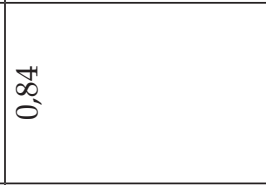 & $\stackrel{0}{0}$ & $\mid \begin{array}{l}\infty \\
0 \\
0\end{array}$ \\
\hline 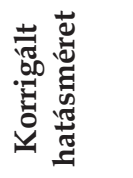 & $\stackrel{\text { ํㅗㅇ }}{\text { - }}$ & $\mid \begin{array}{l}0 \\
\infty \\
0 \\
0\end{array}$ & $\stackrel{\overbrace{}}{\tilde{\Gamma}}$ & $\mid \begin{array}{l}1 \\
\infty \\
0 \\
0\end{array}$ \\
\hline 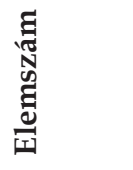 & 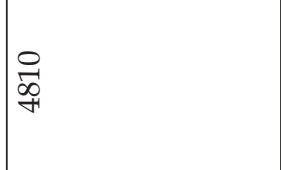 & $\begin{array}{l}\mathbb{2} \\
\stackrel{2}{2}\end{array}$ & 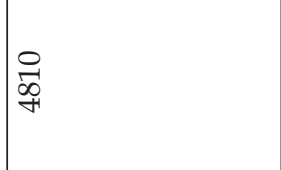 & $\begin{array}{l}\stackrel{1}{2} \\
\text { مิ }\end{array}$ \\
\hline 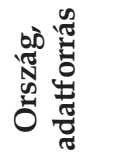 & 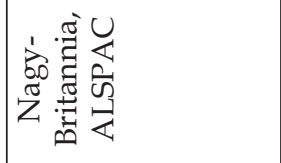 & 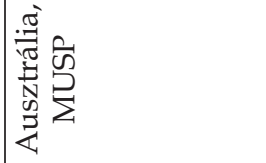 & 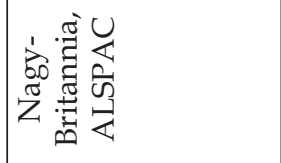 & 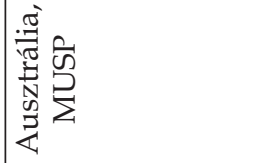 \\
\hline 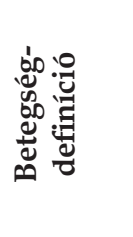 & 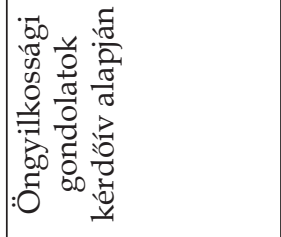 & 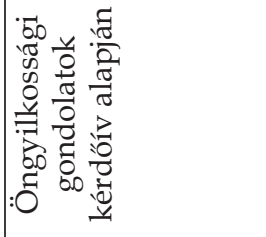 & 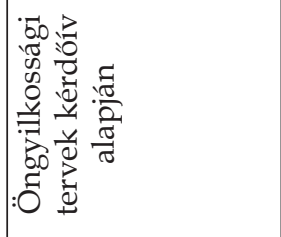 & 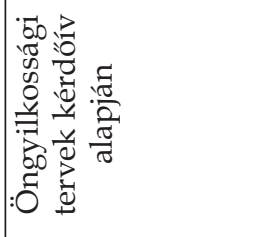 \\
\hline 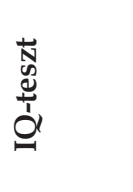 & $\begin{array}{l}\exists \\
0 \\
0 \\
3 \\
3\end{array}$ & 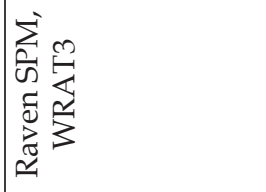 & $\begin{array}{l}\equiv \\
0 \\
0 \\
3 \\
3\end{array}$ & 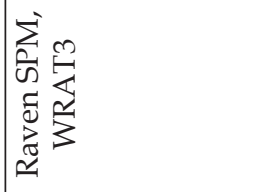 \\
\hline 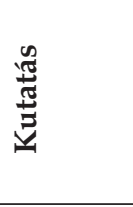 & 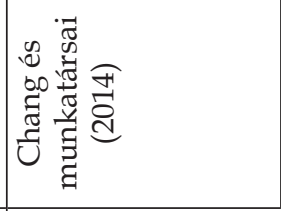 & 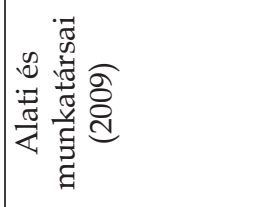 & 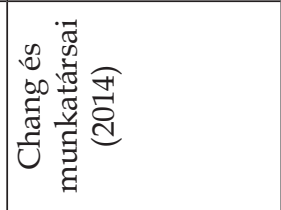 & 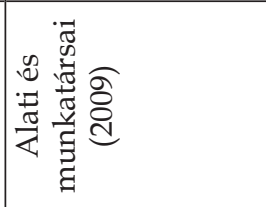 \\
\hline 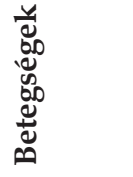 & \multicolumn{2}{|c|}{ Öngyilkossági gondolat } & \multicolumn{2}{|c|}{ Öngyilkossági terv } \\
\hline
\end{tabular}




\begin{tabular}{|c|c|c|c|c|}
\hline 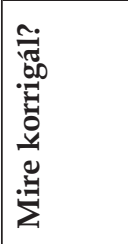 & 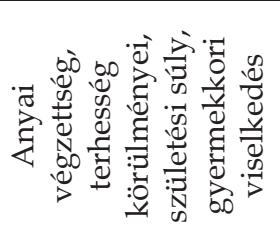 & 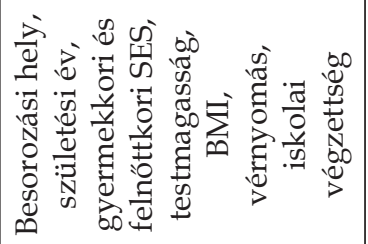 & 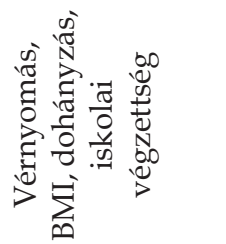 & 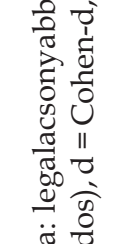 \\
\hline 党 & $\begin{array}{l}\frac{10}{\widehat{O}} \\
\mathrm{o}^{\circ}\end{array}$ & $\begin{array}{l}\infty \\
1 ? \\
0 \\
\vdots\end{array}$ & $\begin{array}{l}\vec{\infty} \\
\infty \\
0\end{array}$ & 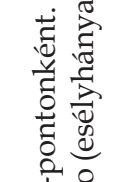 \\
\hline 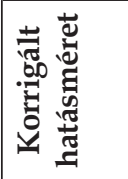 & 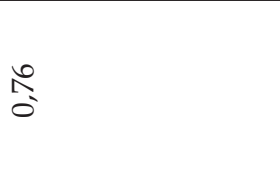 & 孞 & న్ & 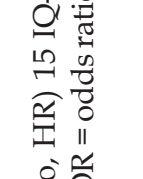 \\
\hline 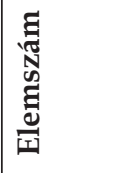 & 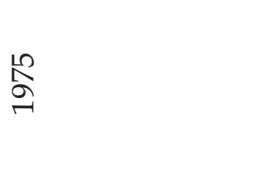 & 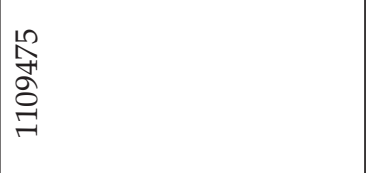 & $\begin{array}{l}\text { ปै } \\
\text { Iै } \\
\text { ू̆ }\end{array}$ & 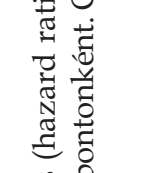 \\
\hline 哫 & 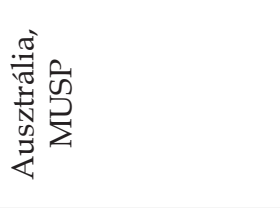 & 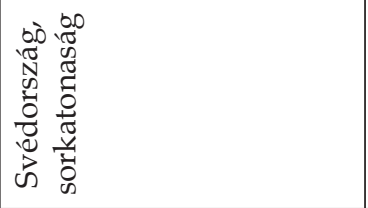 & 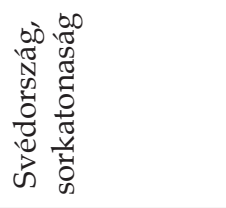 & 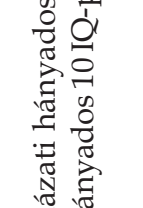 \\
\hline 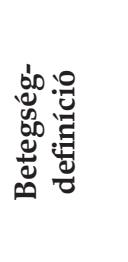 & 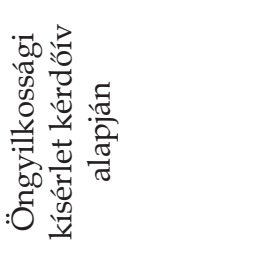 & 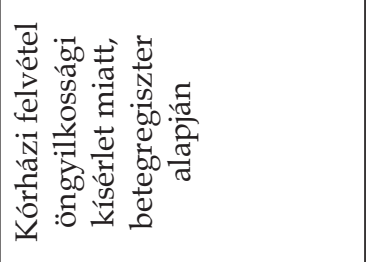 & 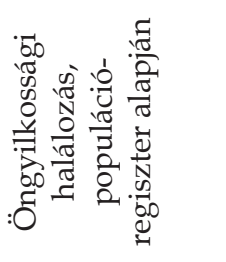 & 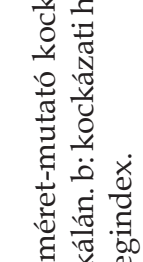 \\
\hline 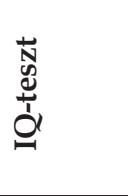 & 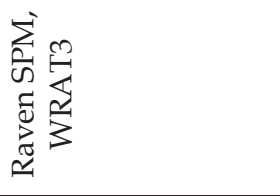 & 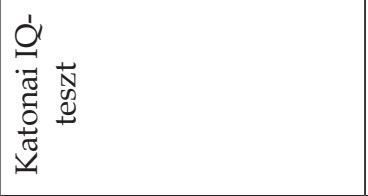 & 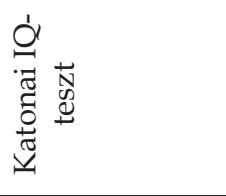 & 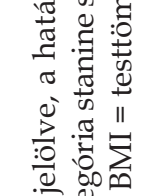 \\
\hline 苞 & 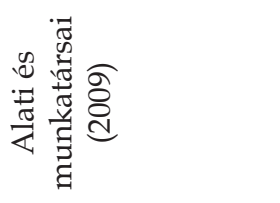 & 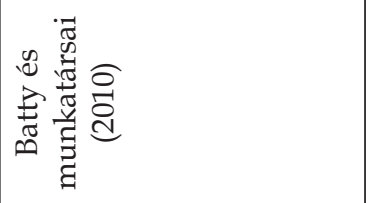 & 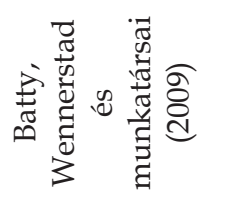 & 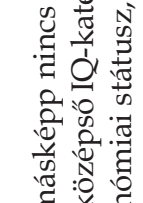 \\
\hline 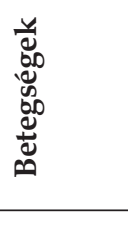 & Öngyilk & ossági kísérlet & $\begin{array}{l}\text { Öngyilkossági } \\
\text { halálozás }\end{array}$ & 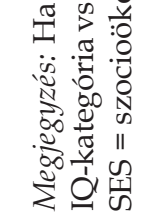 \\
\hline
\end{tabular}




\section{Szomatikus betegségek és mortalitás}

A szomatikus betegségek és a halálozás kognitív epidemiológiai vizsgálatai bizonyos szempontból nagyobb kihívást jelentenek a mentális betegségekéénél. Ennek az az oka, hogy míg a mentális betegségeket jellemzően már fiatal felnőttkorban diagnosztizálják, addig a szomatikus betegségek és különösen a mortalitás jellemzően lényegesen idősebb életkorban következnek be. Emiatt kivételesen hosszan utánkövetett minták szükségesek, hogy pontosan meg tudjuk mérni a premorbid IQ és a szomatikus betegségek, valamint a mortalitás összefüggését. Ezen limitáció miatt a legfontosabb adatforrások a következők (részletes hivatkozásokkal a 2-5. táblázatokban):

- Az 1932-es és 1947-es Skót Mentális felmérések, amelyek az adott években valamennyi 11 éves, egy adott napon iskolába menő skót gyermek IQ-tesztadatáról tartalmaznak adatot (ezek elektronikus betegregiszterekkel köthetőek össze).

- Az aberdeeni 'Children of the 50s' kohorszvizsgálat, amelyben több mint 10000 skót gyermek adatait gyújtötték össze az 1960-as évek elején, és a résztvevőket negyven évvel később kérdőíves módszerrel felmérték egészségi állapotukról.

- A svéd sorkatonai adatbázisok, amelyek évtizedeken át valamennyi besorozott svéd férfi IQ-tesztjét tartalmazzák (ezek elektronikus betegregiszterekkel köthetők össze).

- Az amerikai NLSY-79 longitudinális minta, amelynek jellemzően az 1950-es években született résztvevőit rendszeresen, kérdőíves módszerrel utánkövetik.

- A vietnami háborúban szolgált egykori amerikai katonákat utánkövető Vietnam Experience Study.

\subsection{Mortalitás}

Batty és munkatársai (2009) közel 1 millió svéd sorkatona 20 éves utánkövetésével a sorozáskor mért magasabb intelligenciát szignifikánsan öszszefüggőnek találták az alacsonyabb halálozási kockázattal $(\mathrm{HR}=0,75 / 15$ IQ-pont; a vérnyomás, a testtömegindex, a dohányzás, valamint a szomatikus és pszichiátriai betegségek kontrolljával $H R=0,8 / 15$ IQ-pont; a fentiek mellett az iskolai végzettség kontrolljával $H R=0,89 / 15$ IQ-pont).

Čukić, Brett, Calvin, Batty és Deary (2017) az 1947-es Skót Mentális Felmérés 68 éves utánkövetésénél a 11 évesen mért IQ és a 79 éves korig bekövetkezett halálozás között ugyancsak fordított irányú viszonyt találtak (HR = 0,8/15 IQ-pont). Egy, a vizsgált IQ-tartomány miatt különleges vizs- 
gálatban (Martin \& Kubzansky, 2005) Lewis Terman 897, 1922-ben toborzott, kiemelkedően tehetséges (IQ > 135) növendékének 64 évvel későbbi halálozási kockázatát elemezték. Ebben a kiemelkedően magas intelligenciaövezetben is negatív irányú kapcsolat mutatkozott az intelligencia és a halálozási kockázat között (HR = 0,68/15 IQ-pont).

Calvin és munkatársai (2011) metaanalízise több mint 16 tanulmány és 1 millió résztvevő (többségében svéd sorkatona) elemzése után összességében 15 IQ-pontonként a halálozási kockázat 24\%-os redukcióját találta (OR = 0,76/15 IQ-pont). A gyermekkori szocioökonómiai státusz statisztikai korrekciója nem változtatott az eredményeken, ami arra utal, hogy ez nem szignifikáns mögöttes ok. A felnőttkori szocioökonómiai státusz és iskolai végzettség mint mediáló tényező azonban szignifikáns volt: az IQ és a mortalitás összefüggésének rendre $34 \%$-át és $54 \%$-át mediálták.

A gyakori betegségek és vezető halálokok IQ-val való összefüggésével később részletesen is foglalkozom. Néhány tanulmányban azonban a ritkább halálokoknak az IQ-val való összefüggését is vizsgálták. Calvin és munkatársai (2017) az 1947-es Skót Mentális Felmérés adatai alapján $(H R=0,81)$, Batty és munkatársai (2009) pedig a svéd sorkatonai adatbázisok alapján (HR $=0,64$; az életkor, testtömegindex, vérnyomás, testmagasság, iskolai végzettség, gyermek- és felnőttkori SES kontrolljával $H R=0,94$ ) az IQ és a baleseti halálozás között is negatív irányú összefüggést találtak. A közlekedési balesetek $(H R=0,93)$, mérgezések $(H R=0,76)$, esések $(H R=0,78)$, túzesetek $(H R=0,88)$ és fulladás ( $H R=0,94)$ miatti halálozás esetében is szignifikáns, negatív irányú összefüggés mutatkozott a premorbid IQ-val. (Ezek a hatásméretek a svéd sorkatonai regiszterek alapján, az életkorra, gyermekkori és felnőttkori szocioökonómiai státuszra, testtömegindexre, szisztolés vérnyomásra és iskolai végzettségre való korrekció után, 15 IQ-pontonként értendők.) Batty, Deary, Tengstrom és Rasmussen (2018) eredményei alapján az IQ különösen erősen negatívan függ össze az erőszakos halálozással: a svéd sorkatonai regiszterekben az emberölésból eredő halálozás kockázata 15 IQ-pontonként mintegy a felére csökkent ( $\mathrm{HR}=0,49$; a szocioökonómiai státuszra és a sorozáskori betegségekre való korrekció után HR = 0,57). Egy különleges vizsgálatban (Corley, Crang, \& Deary, 2009) ugyanakkor azt találták, hogy az 1936-os Skót Mentális Felmérés résztvevői közül azok, akik elestek a második világháborúban, szignifikánsan magasabb 11 éves korban mért IQ-val rendelkeztek, mint azok, akik túlélték a háborút. A szerzők elképzelése szerint háborús körülmények között a rosszabb intellektuális képességekkel rendelkező katonákat a rosszabb gyakorlati teljesítményük (Gregory, 2015; Ree, Earles, \& Teachout, 1994) miatt ritkábban osztották be különösen veszélyes frontvonalbeli feladatokra. 


\subsection{Szív- és érrendszeri betegségek}

A szív- és érrendszeri betegségek Magyarországon és a világ más országaiban is a vezetó halálokok közé tartoznak. Jelenleg öt nagy adatbázisból érhetőek el részletes adatok a premorbid IQ és a szív- és érrendszeri betegségek összefüggéséről: a teljes populációs 1947-es Skót Mentális Felmérésből (68 éves utánkövetés, mortalitási és morbiditási adatok elektronikus betegregiszterekből), az aberdeeni 'Children of the 50s' kohorszból (kb. 40 éves utánkövetés, egészségi adatok kérdőíves felmérés alapján), a szintén teljes populációs svéd sorkatonai regiszterekből (20 éves utánkövetés, morbiditási és mortalitási adatok elektronikus regiszterekből), az amerikai Vietnam Experience Studyból (veteránok utánkövetése kb. 53 éves korig, morbiditási adatok 38 éves kori orvosi vizsgálatból, mortalitási adatok az utánkövetés végéig elektronikus regiszterekből), valamint az amerikai NSLY-79-ből (kb. 30 éves utánkövetés 50 éves korra, morbiditási adatok kérdőíves önbevallás alapján). Az ezekból származó eredményeket a 2. táblázat foglalja össze.

Összességében elmondható, hogy az IQ gyakorlatilag valamennyi szívés érrendszeri probléma előfordulásával negatívan függött össze. Az összefüggés azonban a többszörösen - jellemzően a felnőttkori szocioökonómiai státusz valamely elemére is - korrigált modellekben jelentősen csökkent, és olykor meg is szúnt. 


\begin{tabular}{|c|c|c|c|c|c|c|}
\hline 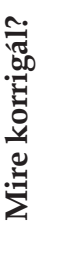 & 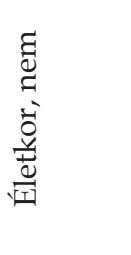 & 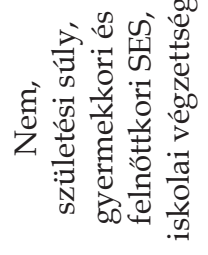 & 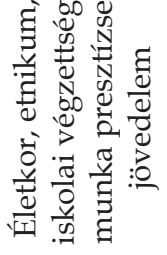 & 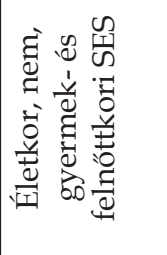 & 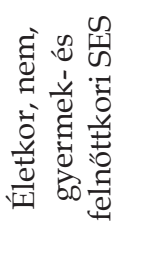 & $\frac{\tilde{0}}{\frac{\overrightarrow{0}}{d}}$ \\
\hline 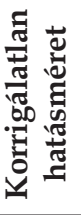 & $\begin{array}{l}0 \\
\stackrel{2}{0}\end{array}$ & જू & $\hat{\sigma}$ & 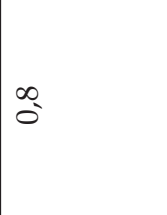 & $\begin{array}{l}\text { ㅁo } \\
\text { ర్ }\end{array}$ & $\begin{array}{l}\infty \\
0 \\
0\end{array}$ \\
\hline 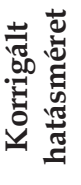 & 1 & $\underset{-}{\mathrm{O}}$ & $\begin{array}{l}\text { 。̊ } \\
\text { o }\end{array}$ & $\begin{array}{l}\infty \\
\infty \\
0 \\
0\end{array}$ & $\stackrel{\infty}{\infty}_{0}^{\infty}$ & 1 \\
\hline 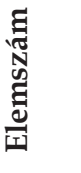 & 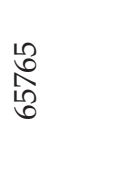 & 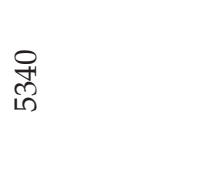 & $\begin{array}{l}\hat{1} \\
\stackrel{F}{F}\end{array}$ & 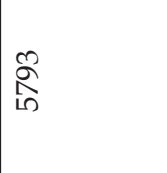 & $\begin{array}{l}\Re \\
\text { ภิ }\end{array}$ & $\begin{array}{l}\infty \\
\infty \\
\infty \\
\infty\end{array}$ \\
\hline 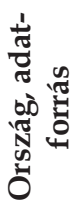 & 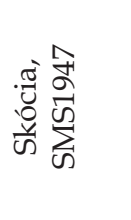 & 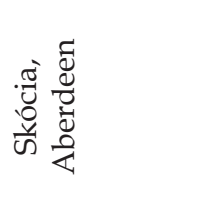 & 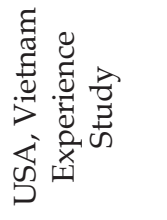 & 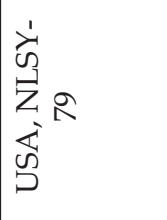 & 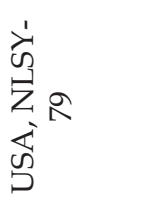 & 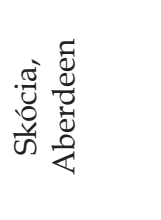 \\
\hline 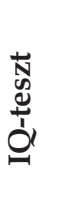 & 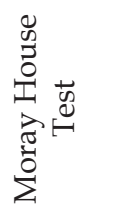 & 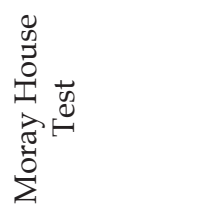 & 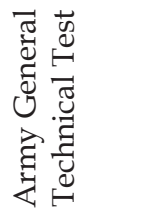 & 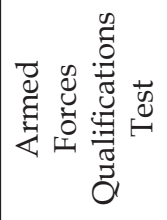 & 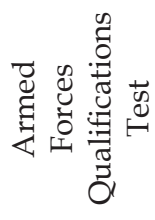 & 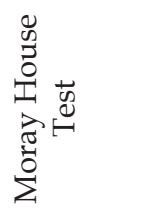 \\
\hline 胥 & 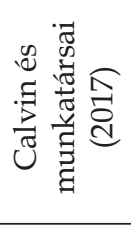 & 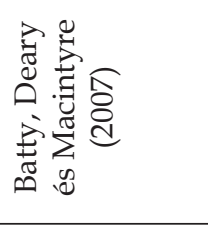 & 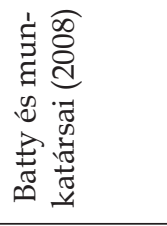 & 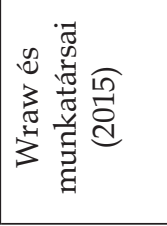 & 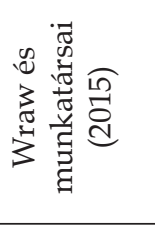 & 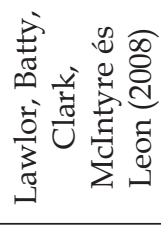 \\
\hline & 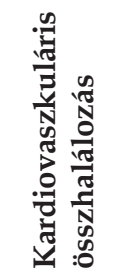 & \multicolumn{3}{|c|}{ 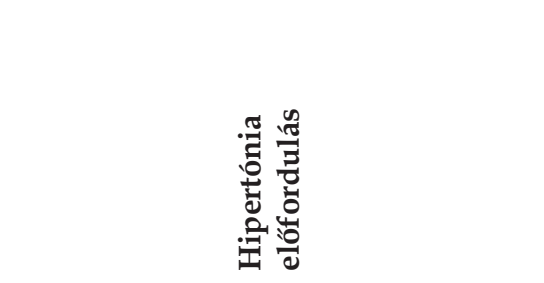 } & \multicolumn{2}{|c|}{ क } \\
\hline
\end{tabular}




\begin{tabular}{|c|c|c|c|c|c|c|}
\hline 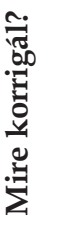 & 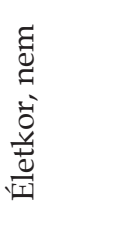 & 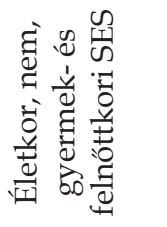 & $\frac{\breve{0}}{\frac{\overrightarrow{0}}{0}}$ & 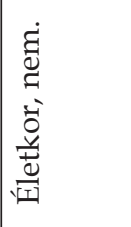 & 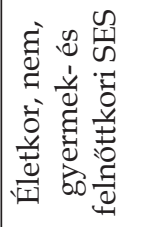 & 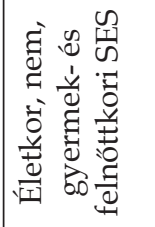 \\
\hline 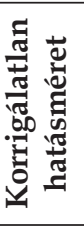 & $\begin{array}{l}\stackrel{0}{\stackrel{5}{\sigma}}\end{array}$ & 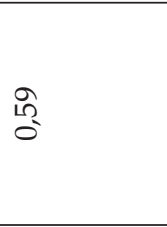 & $\widehat{\widehat{o}}$ & $\frac{12}{0}$ & શ. & రి \\
\hline 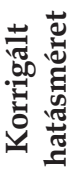 & 1 & a & 1 & 1 & 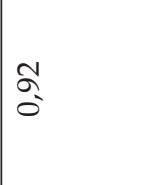 & $\mid \begin{array}{l}\infty \\
0 \\
0\end{array}$ \\
\hline 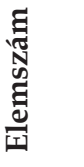 & 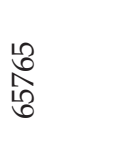 & $\begin{array}{l}\mathscr{\Omega} \\
\text { in }\end{array}$ & $\begin{array}{l}\infty \\
\infty \\
\infty \\
\infty\end{array}$ & $\begin{array}{l}18 \\
18 \\
18\end{array}$ & $\begin{array}{l}\mathscr{\Omega} \\
\text { in }\end{array}$ & $\begin{array}{l}\mathscr{\Upsilon} \\
\hat{\hat{n}}\end{array}$ \\
\hline 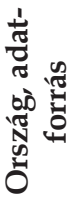 & 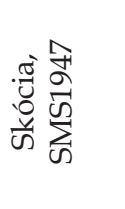 & 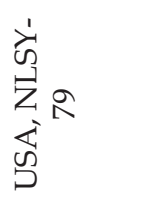 & 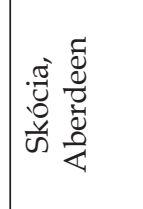 & 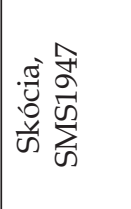 & 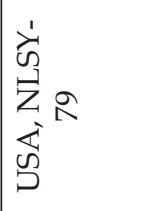 & 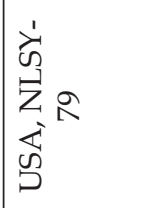 \\
\hline $\begin{array}{l}\vec{N} \\
\stackrel{0}{0} \\
\stackrel{1}{0}\end{array}$ & 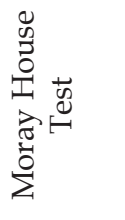 & 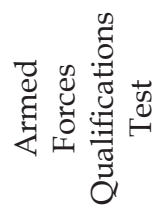 & 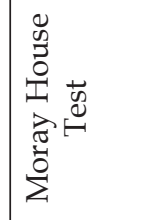 & 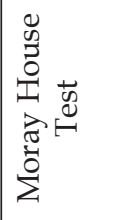 & 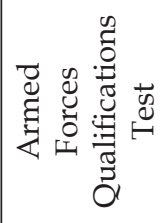 & 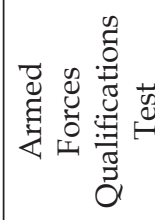 \\
\hline 疍 & 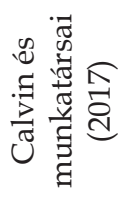 & 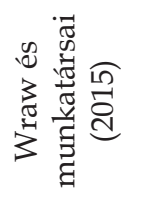 & 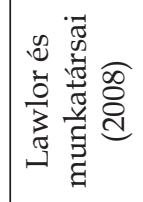 & 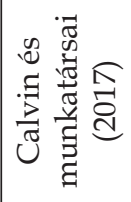 & 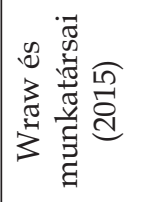 & 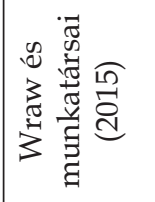 \\
\hline & 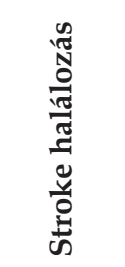 & & 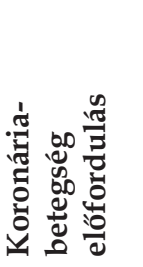 & & 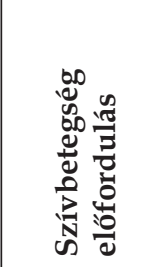 & 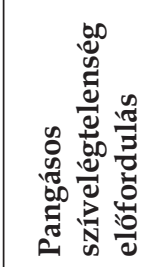 \\
\hline
\end{tabular}




\subsection{Daganatos betegségek}

A daganatos betegségek szintén világszerte vezető haláloknak számítanak. A daganatos betegségek kognitív epidemiológiájával kapcsolatban két vizsgálat különösen kiemelkedő. Calvin és munkatársai (2017) az 1947-es Skót Mentális Felmérés eredményeit kötötték össze elektronikus halálozási regiszterekkel, amelyek a halál okát is tartalmazták. A felmérésból gyakorlatilag valamennyi, 1936-ban Skóciában született gyermek IQ-ja megismerhetó volt. Ennek a mintának az előnye a hosszú utánkövetési idő és az ebből következő magas halálozási arány (az eltelt 68 évben a több mint 65 ezer fős mintában több mint 25 ezer halálozás történt). Hátránya viszont, hogy a minta egészében csak életkorra és nemre való statisztikai korrekció lehetséges az egyéb adatok hiányossága miatt. Batty és munkatársai (2007) a svéd sorkatonai regisztereket kapcsolták össze elektronikus halálozási regiszterekkel. Ez az adatbázis a huszadik század második felének jelentős részében született gyakorlatilag valamennyi svéd férfi (több mint 1 millió fó) 18 éves korban mért IQ-ját tartalmazza. Ennek a mintának az előnye rendkívül nagy mérete és a potenciális mögöttes okok és mediáló tényezők széles körú korrigálhatósága; hátránya viszont a rövid (a sorkatonai szolgálat kezdetétól átlagosan 19,5 évig tartó) utánkövetési idő, ami miatt a résztvevőknél várható daganatos halálozás nagy része az utánkövetési időben nagy valószínúséggel még nem következett be.

Calvin és munkatársai (2017) negatív irányú összefüggést találtak a premorbid IQ és a várható daganatos halálozás között. Ez azonban elsősorban a dohányzással összefüggő daganatokra (HR = 0,82/15 IQ-pont) volt igaz, a dohányzással nem összefüggő daganatokra lényegesen kevésbé (HR = 0,96/15 IQ-pont). A dohányzással összefüggő daganatok szinte kizárólagos összefüggését az IQ-val (HR = 0,73/15 IQ-pont) egy, az amerikai Vietnam Experience Study az ötvenes életéveik elejéig utánkövetett elemzése is megerősíti (Batty és mtsai, 2009). A nem egészen 40 éves korig utánkövetett svéd sorkatonák vizsgálata Batty és munkatársai (2007) elemzésében azonban kifejezetten pozitív irányú összefüggést talált a magasabb premorbid IQ és a (fiatalkori) tüdődaganat előfordulása között. A 3. táblázat a daganatos összmorbiditás és összmortalitás vizsgálatait, a 4. táblázat pedig a két legfontosabb vizsgálat eredményeit ismerteti, daganattípusokra lebontva. Összességében véve elmondható, hogy a dohányzással összefüggó daganatokat, elsősorban a tüdődaganatot leszámítva az IQ kevés daganattípus előfordulásával és halálozásával függ össze. A rendelkezésre álló eredményeknek azonban fontos limitációja, hogy kellően hosszú utánkövetés és a mediáló tényezők kellően alapos felmérése jelenleg egyetlen adatbázisban sem érhetó el. 


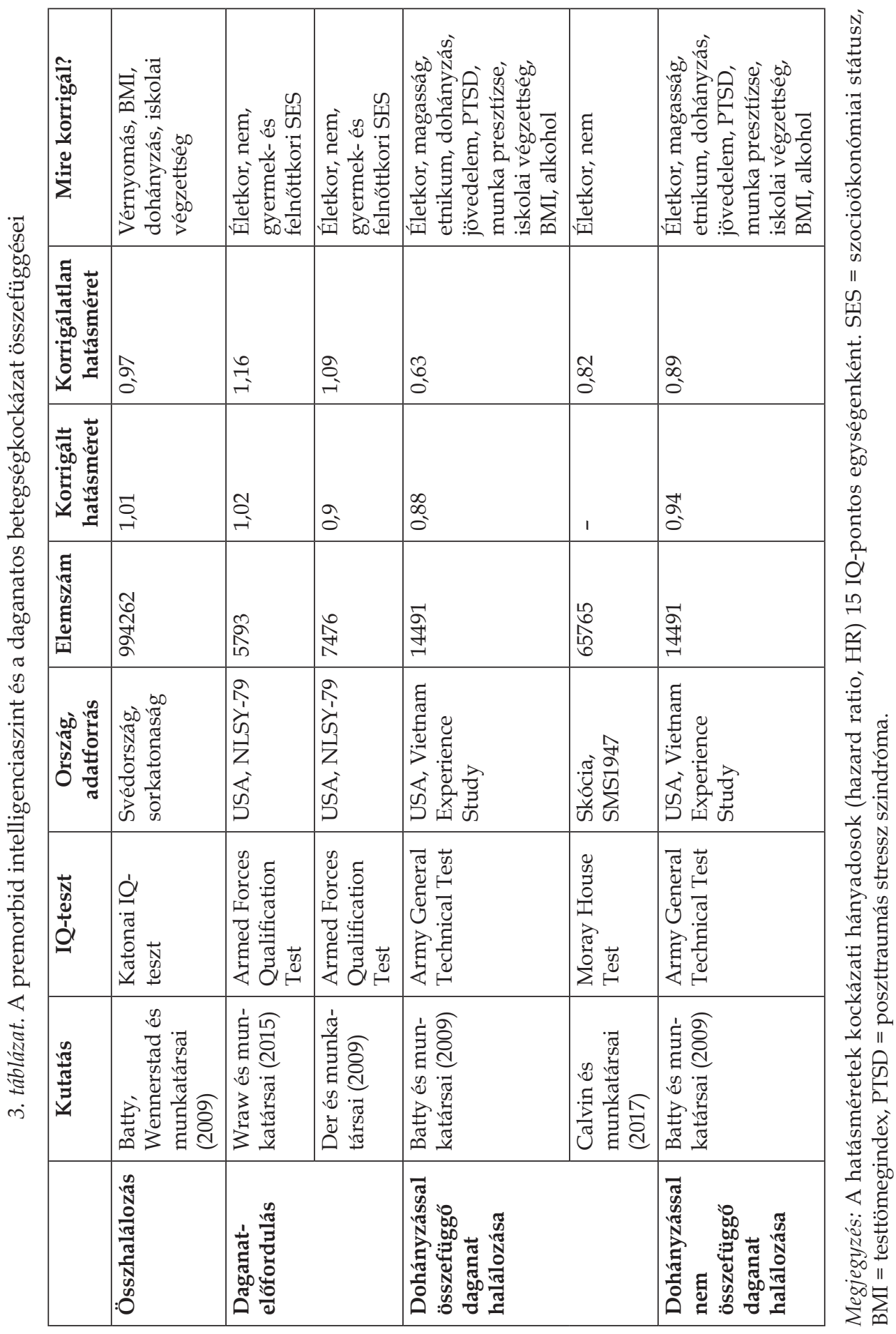


4. táblázat. Specifikus daganattípusok összefüggése a premorbid IQ-val

\begin{tabular}{|c|c|c|c|}
\hline \multirow{2}{*}{ Daganattípusok } & \multicolumn{2}{|c|}{$\begin{array}{c}\text { Batty és munkatársai (2007) } \\
\text { (eloofordulás) }\end{array}$} & \multirow{2}{*}{$\begin{array}{l}\text { Calvin és munkatársai } \\
\text { (2017) (halálozás) }\end{array}$} \\
\hline & $\begin{array}{c}\text { Korrigált } \\
\text { hatásméret }\end{array}$ & $\begin{array}{l}\text { Korrigálatlan } \\
\text { hatásméret }\end{array}$ & \\
\hline Tüdőrák & 1,09 & 1,01 & 0,75 \\
\hline Bőrrák & 1,1 & 1,18 & 1,03 \\
\hline Hasnyálmirigyrák & 1,02 & 0,86 & 0,93 \\
\hline Hererák & 1,1 & 1,05 & - \\
\hline Szemdaganat & 1,05 & 0,96 & - \\
\hline Száj- és garatrák & 0,97 & 0,92 & 0,97 \\
\hline Nyelőcsőrák & 0,85 & 0,76 & 0,95 \\
\hline Gyomorrák & 0,92 & 0,82 & 0,75 \\
\hline Vastag- és végbéldaganat & 0,98 & 0,97 & 0,89 \\
\hline Gégerák & 0,89 & 0,93 & \\
\hline Prosztatarák & 0,92 & 1,03 & 1,03 \\
\hline Csontrák & 0,99 & 1,02 & 0,99 \\
\hline Vérképzőrendszeri daganat & 0,99 & 1,02 & 0,91 \\
\hline Májrák & 0,88 & 0,85 & 0,85 \\
\hline Veserák & 0,93 & 0,83 & 0,91 \\
\hline Húgyhólyagrák & 0,88 & 0,9 & 0,81 \\
\hline Agydaganat & 0,96 & 0,97 & 0,95 \\
\hline Mellrák & - & - & 1,01 \\
\hline
\end{tabular}

Megjegyzés: A hatásméretek kockázati hányadosok (hazard ratio, HR) 15 IQ-pontos egységenként. Batty és munkatársai (2007) vizsgálatában a korrigált hatásméreteknél az életkor, a testtömegindex, a testmagasság, az iskolai végzettség, és szülői társadalmi osztály statisztikai korrekciója történt meg. A Calvin és munkatársai (2017) által leírt hatásméretek nemre és életkorra korrigáltak.

\subsection{Egyéb betegségek és egészség-magatartás}

Egyes adatbázisok egyéb betegségekről, illetve egészség-magatartással kapcsolatos tényezőkről is rendelkeznek adatokkal. Ezek közül kiemelkednek az amerikai NSLY-79 kérdőíves felmérései. 
Egy nagyon részletes egészségi felmérésben Der és munkatársai (2009) az amerikai NLSY-79 longitudinális vizsgálat összesen több mint 7000 résztvevőjénél vizsgálta a serdülő- vagy fiatalkori IQ és a 40 éves korban mért egészségi állapot összefüggéseit. A résztvevők önbevallással nyilatkoztak arról, hogy diagnosztizáltak-e náluk egy sor egészségi problémát. A nemre, korra és szocioökonómiai státuszra korrigált adatok alapján a magasabb intelligencia a következő betegségek szignifikánsan alacsonyabb kockázatával függött össze: szemproblémák (szemüvegviselésen kívül, HR = 0,67), fekélyek (HR =0,71), súlyos fog-és ínyproblémák $(H R=0,73)$, epilepszia vagy rohamok $(\mathrm{HR}=0,74)$, gyomor- vagy bélfekélyek $(\mathrm{HR}=0,76)$, gyakori alvásproblémák (HR =0,77), gyakori fejfájás, szédülés vagy ájulás $(\mathrm{HR}=0,8)$, mellkasi fájdalom és palpitáció $(\mathrm{HR}=0,8)$, anémia $(\mathrm{HR}=0,83)$, lábpanaszok $(\mathrm{HR}=0,84)$, asztma $(\mathrm{HR}=0,87)$, depresszió vagy szorongás $(\mathrm{HR}=0,88)$. Az eredmények szerint az intelligencia nem függött össze szignifikánsan a következő betegségek kockázatával: neuritis $(\mathrm{HR}=0,84)$, veseés húgyhólyag-problémák ( $\mathrm{HR}=0,88)$, érelmeszesedés ( $\mathrm{HR}=0,89)$, gyakori húgyúti fertőzések $(\mathrm{HR}=0,9)$, skarlát $(\mathrm{HR}=0,93)$, hátproblémák $(\mathrm{HR}=0,96)$, csontritkulás ( $\mathrm{HR}=1,01)$, emésztési, gyomor és májpanaszok $(\mathrm{HR}=1,02)$, váll-, könyök- és térdfájdalmak $(\mathrm{HR}=1,04)$, fül-orr-gégészeti problémák (HR $=1,02)$, alacsony vérnyomás $(H R=0,94)$, bőrbetegségek $(\mathrm{HR}=1,16)$, gyógyszermellékhatások $(\mathrm{HR}=1,06)$, csont- és ízületi deformációk $(H R=0,84)$, tumorok, kinövések és ciszták $(H R=1,27)$, kéz- vagy lábujj elvesztése $(H R=1,64)$. Végül mindössze négy betegség kockázata nőtt meg a magasabb intelligenciaszint esetében: krónikus megfázás $(\mathrm{HR}=1,08)$, pajzsmirigyprobléma $(\mathrm{HR}=1,23)$, arthritis $(\mathrm{HR}=1,23)$, valamint magas koleszterinszint $(\mathrm{HR}=1,26)$.

Wraw és munkatársai (2015) 10 évvel később ugyanebből a mintából közel 6000 résztvevőt vizsgáltak meg egy újabb kérdőíves vizsgálattal, immár 50 éves korban. A gyerek- és felnőttkori szocioökonómiai státusz és az életkor statisztikai kontrolljával 15 IQ-pontonként 15\%-kal ritkább volt a magas vérnyomás, 1\%-kal a cukorbetegség és a krónikus tüdőbetegség, 8\%-kal a szívbetegségek (ezen belül 20\%-kal a pangásos szívelégtelenség), 20\%-kal a stroke, 13\%-kal a csontritkulás és 31\%-kal a szívroham. A viszonylag kevés beteg miatt ezek közül csak a magas vérnyomás és a szívroham különbsége volt statisztikailag szignifikáns. A magasabb intelligenciájú emberek viszont 15 IQ-pontonként 2\%-kal gyakrabban szenvedtek daganatoktól, 2\%-kal reumától, 4\%-kal asztmától, 11\%-kal ízületi bántalmaktól és 10\%-kal gyakrabban használtak mozgáskönnyítő eszközöket, például botot vagy kerekesszéket. A fentiek közül az ízületi bántalmakkal mutatkozó összefüggés volt statisztikailag szignifikáns.

Az egészség-magatartás legnagyobb kognitív epidemiológiai vizsgálatában Wraw, Der, Gale és Deary (2018) az amerikai NLSY-79 longitudinális 
minta 5347, ötvenes évei elején járó résztvevőjének küldtek ki részletes interjúkérdéseket az egészség-magatartásukkal kapcsolatban. A kor, a nem, az etnikum, valamint a gyerek- és felnőttkori szocioökonómiai státusz hatásait statisztikailag kontrollálták. Ezen korrekciók után azok, akiknek a fiatalkori IQ-ja egy szórással magasabb volt, középkorúként 9\%-kal gyakrabban végeztek súlyzós és 13\%-kal gyakrabban végeztek legalább közepes intenzitású kardiovaszkuláris edzést. A magasabb IQ-júak szórásonként 23\%-kal gyakrabban fogyasztottak alkoholt az utóbbi egy hónapban, viszont $17 \%$-kal ritkábban fogyasztottak el egyszerre hat italt vagy többet, és 19\%-kal ritkábban dohányoztak. 18\%-kal gyakrabban használtak fogselymet és 16\%-kal ritkább volt, hogy nem mostak mindennap fogat. A fentieken túl 24-25\%-kal gyakoribb volt a körükben, hogy saját bevallásuk szerint "gyakran" elolvassák bevásárláskor a megvett termékek összetevőit és kalóriatartalmát, és 66-70\%-kal ritkább, hogy „soha”. Érdekes módon viszont 16\%-kal gyakrabban hagytak ki étkezést és 38\%-kal gyakrabban nassoltak étkezések között. A gyorsételek és cukros üdítőitalok fogyasztásában nem mutatkozott szignifikáns különbség az IQ függvényében.

További, gyakrabban vizsgált betegségekből származó adatokat (beleértve néhány gyakori betegséggel kapcsolatos eredményt a fent részletezett vizsgálatokból) az 5. táblázat szemléltet. 


\begin{tabular}{|c|c|c|c|c|c|}
\hline 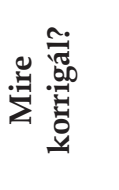 & 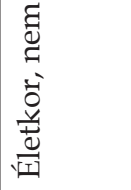 & 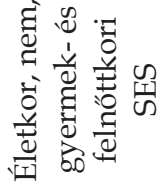 & 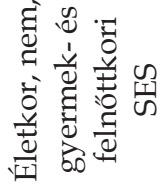 & 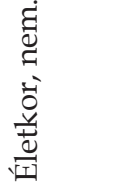 & 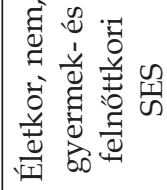 \\
\hline 空芯茪 & $\frac{N}{\tilde{N}}$ & 총 & $\begin{array}{l}\text { §̊ } \\
\text { ó }\end{array}$ & $\begin{array}{l}\infty \\
\infty \\
0 \\
0\end{array}$ & 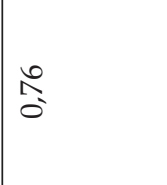 \\
\hline 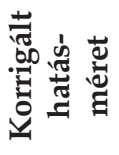 & 1 & જ. & $\underset{+}{\stackrel{D}{+}}$ & 1 & શิ \\
\hline 党 & $\begin{array}{l}10 \\
0 \\
10\end{array}$ & ๙ิ & $\begin{array}{l}\text { న } \\
\text { ถิ }\end{array}$ & $\begin{array}{l}\qquad 2 \\
12 \\
18\end{array}$ & 点 \\
\hline 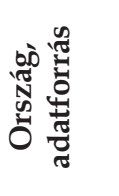 & 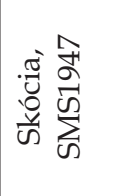 & 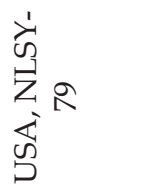 & 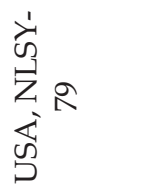 & 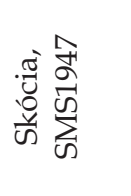 & 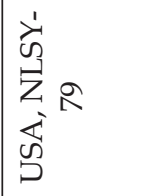 \\
\hline 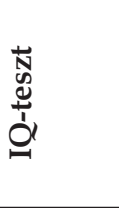 & 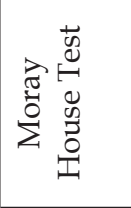 & 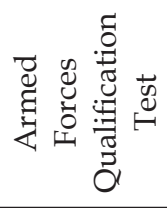 & 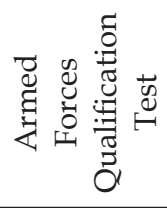 & 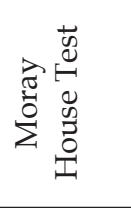 & 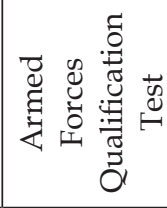 \\
\hline 䒿 & 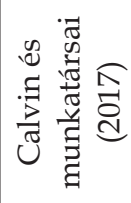 & 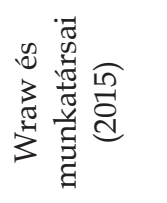 & 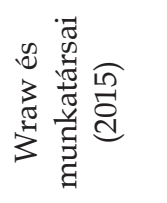 & 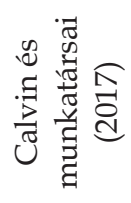 & 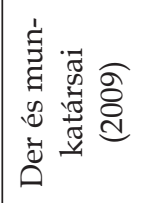 \\
\hline 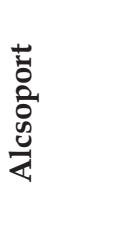 & 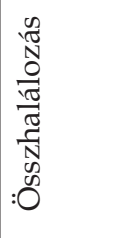 & 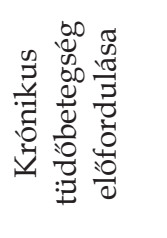 & 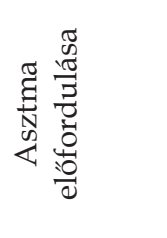 & $\begin{array}{l}\text { त̃ } \\
\text { No } \\
\frac{0}{\pi} \\
\frac{\pi}{\pi} \\
\frac{\pi}{N} \\
0 \\
: 0\end{array}$ & 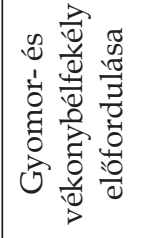 \\
\hline & \multicolumn{3}{|c|}{ 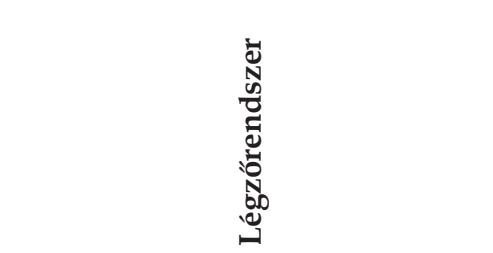 } & \multicolumn{2}{|c|}{ 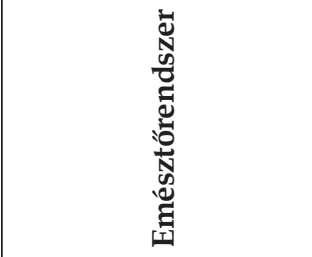 } \\
\hline
\end{tabular}




\begin{tabular}{|c|c|c|c|c|}
\hline 营 & 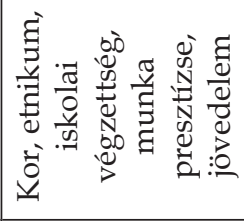 & 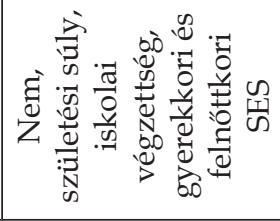 & 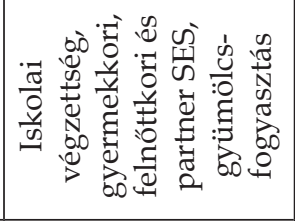 & 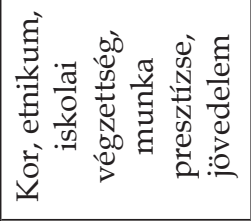 \\
\hline 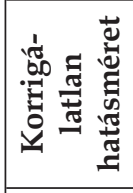 & $\begin{array}{l}\infty \\
\infty \\
0\end{array}$ & ò & 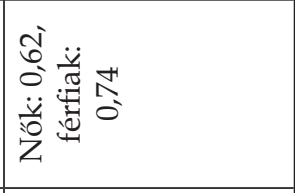 & $\begin{array}{l}\infty \\
0 \\
0\end{array}$ \\
\hline 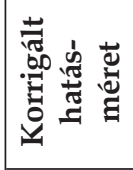 & 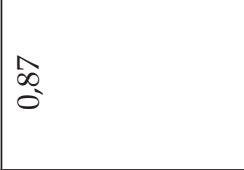 & $\begin{array}{l}\infty \\
\stackrel{\infty}{0} \\
0\end{array}$ & 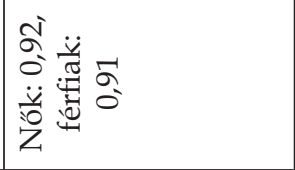 & $\mid \begin{array}{l}0 \\
\infty \\
0\end{array}$ \\
\hline 豈 & $\begin{array}{l}\hat{n} \\
7\end{array}$ & 윔 & $\underset{⿱}{\stackrel{+}{+}}$ & $\begin{array}{l}\hat{10} \\
7\end{array}$ \\
\hline 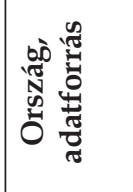 & 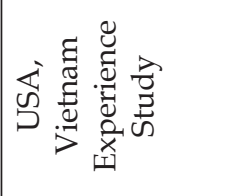 & 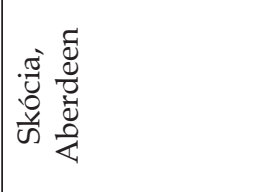 & 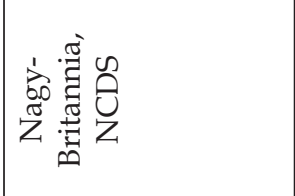 & 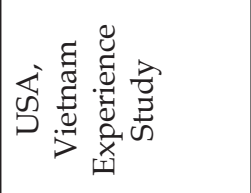 \\
\hline 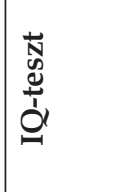 & 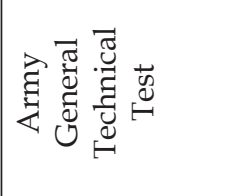 & 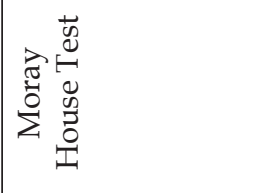 & 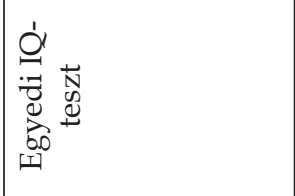 & 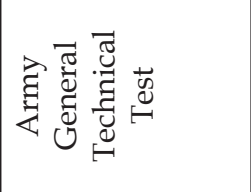 \\
\hline 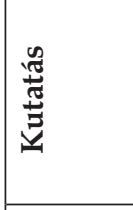 & 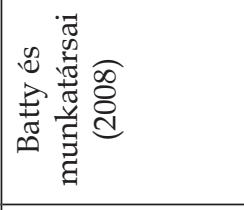 & 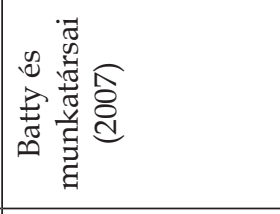 & 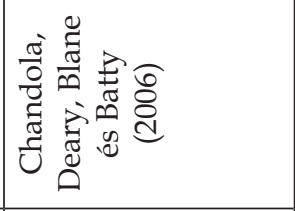 & 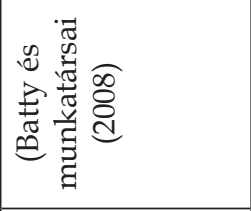 \\
\hline 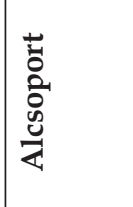 & 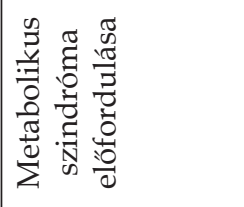 & 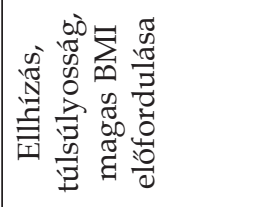 & & \\
\hline & \multicolumn{4}{|c|}{ 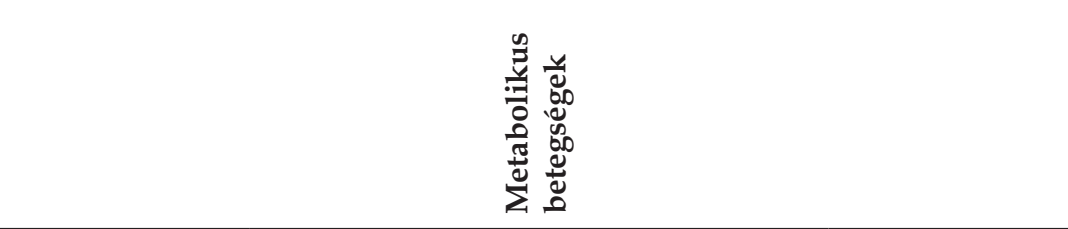 } \\
\hline
\end{tabular}




\begin{tabular}{|c|c|c|c|c|}
\hline 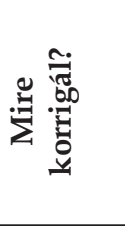 & 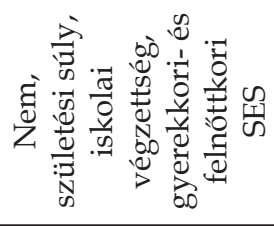 & 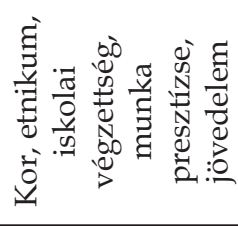 & 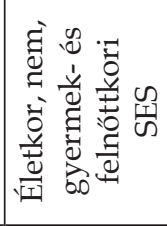 & 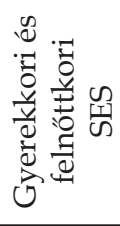 \\
\hline 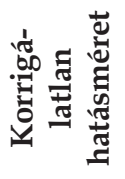 & న్ & $\begin{array}{l}\frac{1}{2} \\
0\end{array}$ & $\begin{array}{l}18 \\
0 \\
0\end{array}$ & $\stackrel{\infty}{0}^{\infty}$ \\
\hline 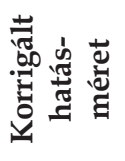 & $\stackrel{\stackrel{ }{N}}{\sim}$ & 命 & જे & 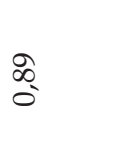 \\
\hline 总 & $\begin{array}{l}\text { Pे } \\
\text { ก̂ }\end{array}$ & $\begin{array}{l}\hat{0} \\
\text { F }\end{array}$ & 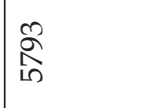 & $\stackrel{+\infty}{\stackrel{\infty}{ }}$ \\
\hline 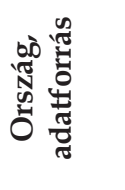 & 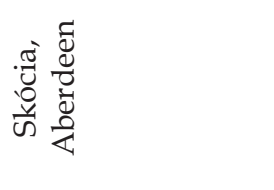 & 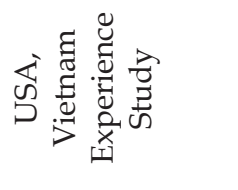 & 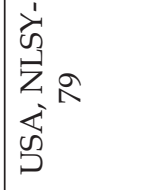 & 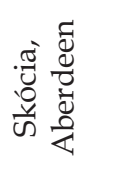 \\
\hline 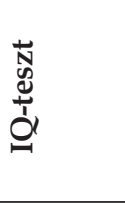 & 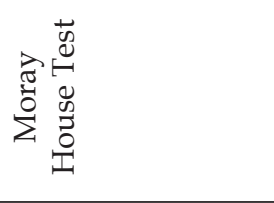 & 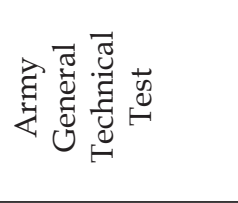 & 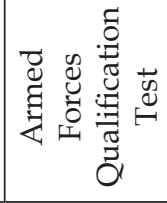 & 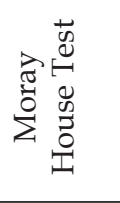 \\
\hline 胥 & 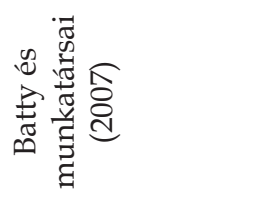 & 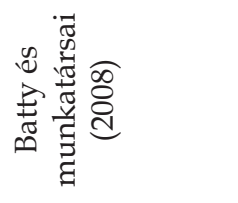 & 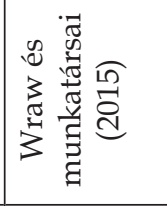 & 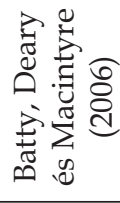 \\
\hline 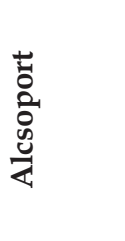 & 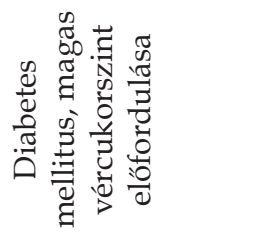 & & & 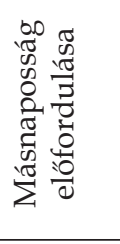 \\
\hline & & & & \\
\hline
\end{tabular}




\section{Nonlineáris hatások, specifikus képességek}

A kognitív epidemiológiai vizsgálatok többsége egyetlen hatásméret-mutatóval, a kockázati hányadossal fejezi ki az intelligencia és az egészségi kockázat viszonyát. A kockázati hányados - nevéből adódóan - alapvetóen egy nonlineáris hatást (a betegség vagy halálozás esélyének exponenciális változását az IQ függvényében) implikál. Az IQ és az egészségi kockázat összefüggése azonban ennél bonyolultabb is lehet. A pszichiátriai betegségek kockázata valóban exponenciálisan nó az alacsonyabb IQ-val (Gale és mtsai, 2010; Zammit és mtsai, 2004), míg a halálozásé inkább lineárisan (Calvin és mtsai, 2017; Čukić és mtsai, 2017) (3-4. ábra).

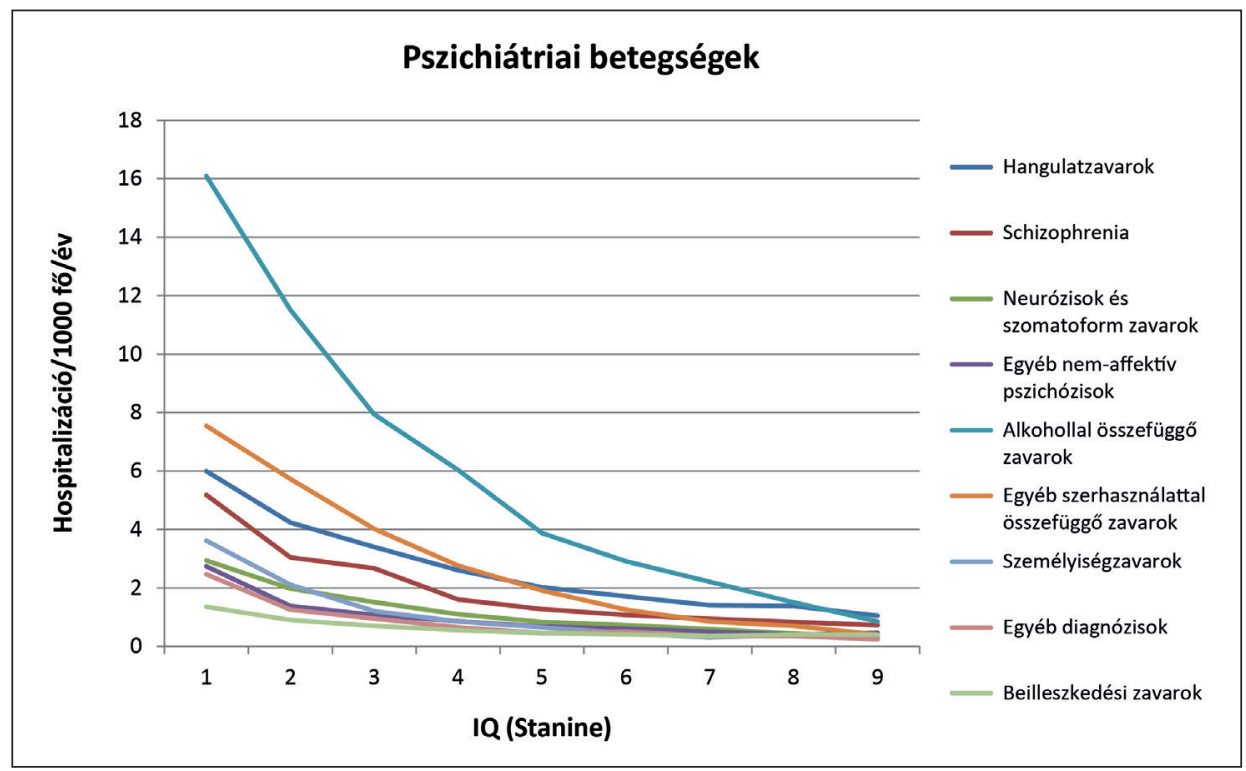

3. ábra. Az intelligenciaszint és a pszichiátriai betegségkockázat összefüggése válogatott vizsgálatok alapján Gale és munkatársai (2010) eredményei alapján

Megjegyzés: Gale és munkatársai (2010) csak grafikus formában közlik adataikat, ezeket a graphreader.com online eszközzel konvertáltam számokká, amelyek ezért hozzávetőlegesek. Az ábra a vizsgálatban közölt maximálisan korrigált hatásméreteket mutatja.

Egy másik fontos kérdés a specifikus kognitív képességek potenciális szerepe a morbiditási és mortalitási kockázat közvetítésében. A legtöbb kognitív epidemiológiai vizsgálat egy területáltalános kognitív képességet feltételezve a teljes IQ-pontszámot használja független változóként. Ennek a megközelítésnek a különböző IQ-tesztek eredménye közötti magas korreláció (Jensen, 1980), különösen a magas látens korreláció (Floyd és mtsai, 


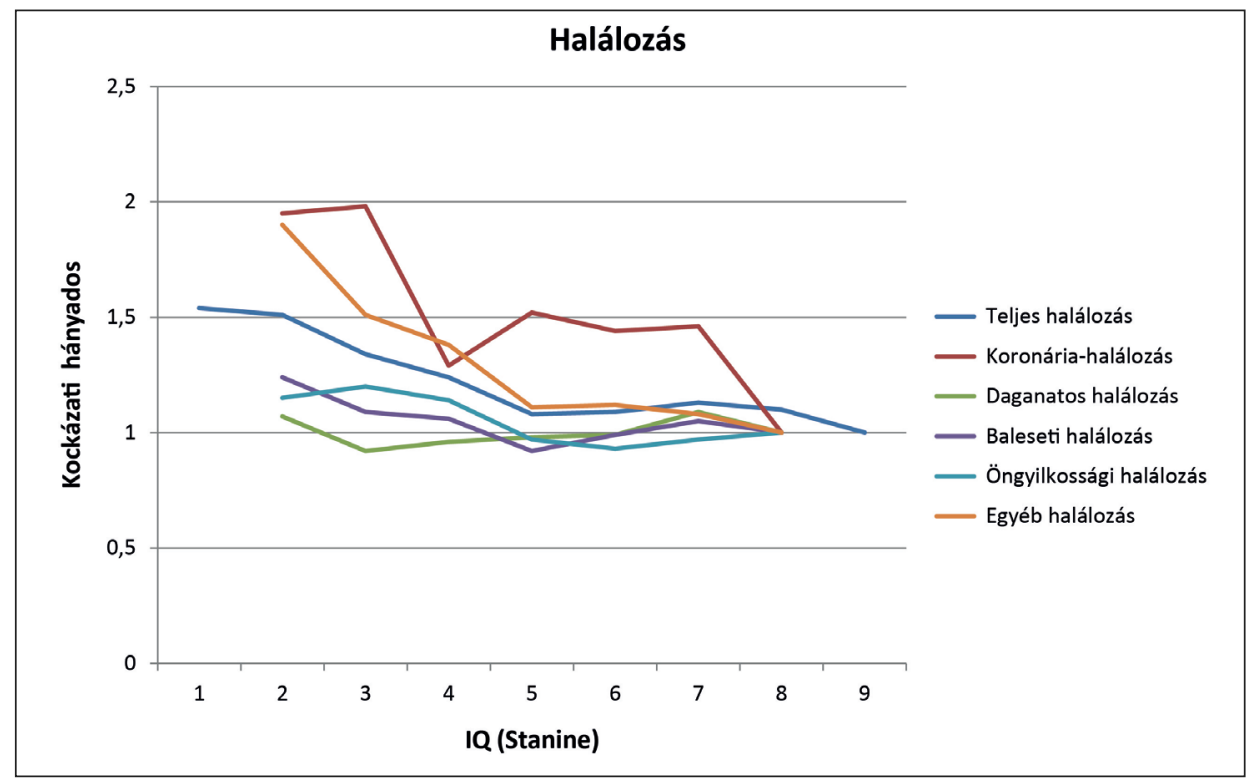

4. ábra. Az intelligenciaszint és a kórokspecifikus halálozás

Batty és munkatársai (2009) eredményei alapján

Megjegyzés: Batty és munkatársai (2009) a kórokspecifikus halálozások esetében az 1-2 és 8-9 stanine-értékeket összevonva kezelték, ezért itt csak hét kategória szerepel az ábrán. A függőleges tengely az egyes stanine-kategóriáknak a legmagasabb kategóriához hasonlított relatív kockázati hányadosát mutatja. Az ábra a vizsgálatban közölt maximálisan korrigált hatásméreteket mutatja.

2013; Johnson és mtsai, 2004; Johnson és mtsai, 2008; Major és mtsai, 2011) ad elméleti alapot: bár számtalan IQ-teszt van használatban, statisztikailag nagyon hasonló eredményt kapunk, bármelyiket is használjuk mintánkban. Néhány vizsgálatban azonban ennél részletesebb adatok is elérhetőek, különösen a svéd sorkatonákon felvett IQ-teszt különböző (logikai, verbális, téri és technikai) komponenseivel kapcsolatban. Az 5-8. ábrák négy ilyen vizsgálat eredményeit összegzik:

1. Pearce, Deary, Young és Parker (2006): 717 fős, 1947-es brit születési kohorsz 2003-ig megtörtént teljes halálozása a 11 éves korban kitöltött IQ-tesztek, valamint anyanyelvismereti és számolási tesztek függvényében (5. ábra).

2. Shipley, Der, Taylor és Deary (2008): több mint hatezer, 18-97 éves brit személy 21 éves utánkövetése, a kórokspecifikus mortalitás esélyének becslése hat különböző kognitív teszt eredményének függvényében (6.ábra).

3. Silventoinen, Modig-Wennerstad, Tynelius és Rasmussen (2007): több mint 680 ezer svéd sorkatona 18-32 éves utánkövetése, a koronáriabetegség miatti halálozás előfordulása a teljes IQ-teszt, valamint négy komponense függvényében (7.ábra). 
4. Zammit és munkatársai (2004): kb. 50000 svéd sorkatona 27 éves utánkövetése, a pszichiátriai betegfelvétel alakulása a teljes sorkatonai IQ-teszt és annak négy komponense függvényében (8. ábra).

Ezek a komponensek összességében az IQ-tesztek összpontszámához hasonló irányú és erősségú összefüggést mutatnak a morbiditási és mortalitási kockázattal (5-8. ábra). Az ezzel kapcsolatos szakirodalom azonban egyelöre nem konkluzív, mert kevés feladat-kockázati mutatópárral kapcsolatban van kellő számú és részletességú vizsgálat. Mindazonáltal idős személyeknél vélhetően erős hipotézis lehet, hogy specifikus feladatok teljesítményromlása (például emlékezeti vagy reakcióidő-feladatok esetében) a teljes pszichometriai intelligenciától függetlenül is rossz egészségi prognózisra utal.

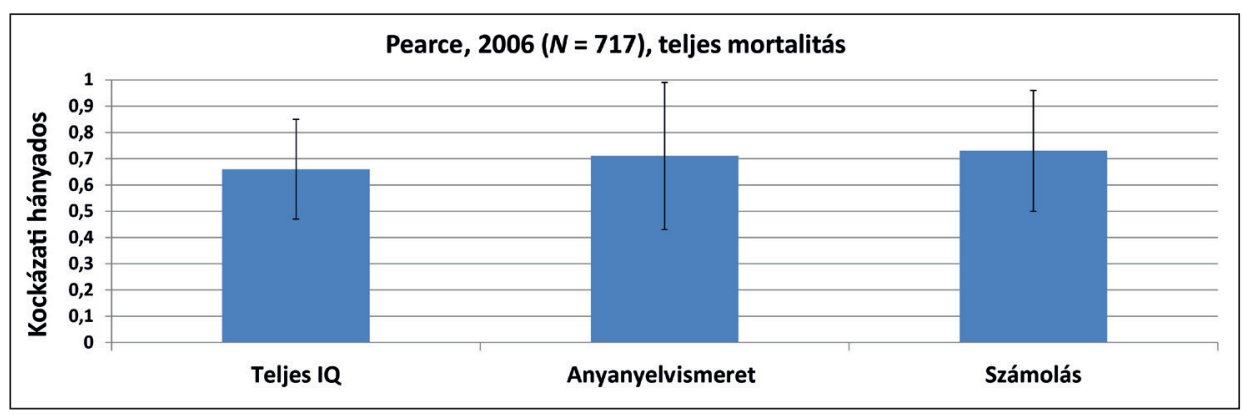

5. ábra. Kognitív képességek és a teljes halálozási kockázat összefüggése Pearce és munkatársai (2006) vizsgálata alapján.

Megjegyzés: A hibavonalak a hatásméret 95\%-os konfidencia-intervallumát ábrázolják. A hatásméretek polaritása az eredeti vizsgálatnak megfelelő, a negatív kockázati hányadosok utalnak arra, hogy az alacsonyabb intelligencia magasabb egészségügyi kockázattal jár.

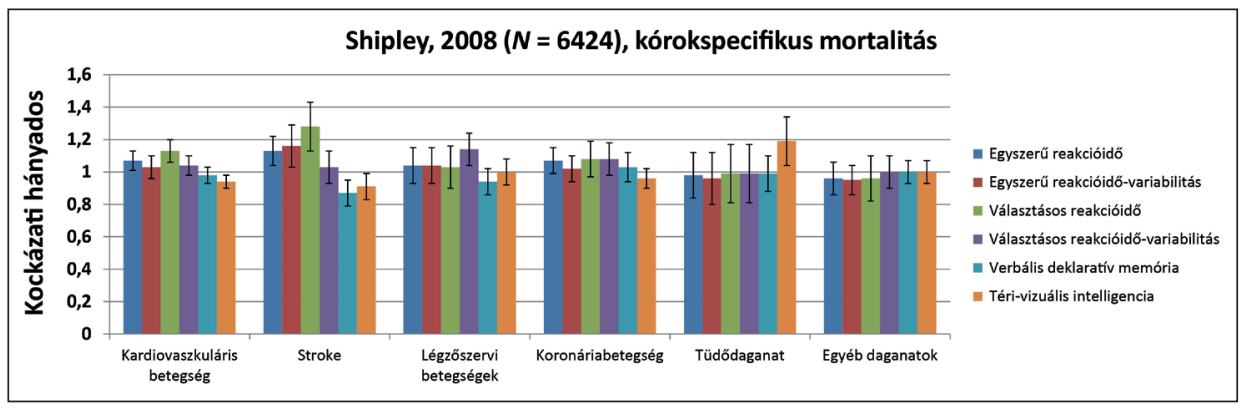

6. ábra. Kognitív képességek és a kórokspecifikus halálozási kockázat összefüggése Shipley és munkatársai (2008) vizsgálata alapján.

Megjegyzés: A hibavonalak a hatásméret 95\%-os konfidencia-intervallumát ábrázolják. A hatásméretek polaritása az eredeti vizsgálatnak megfelelő, a pozitív kockázati hányadosok utalnak arra, hogy az alacsonyabb intelligencia magasabb egészségügyi kockázattal jár. 


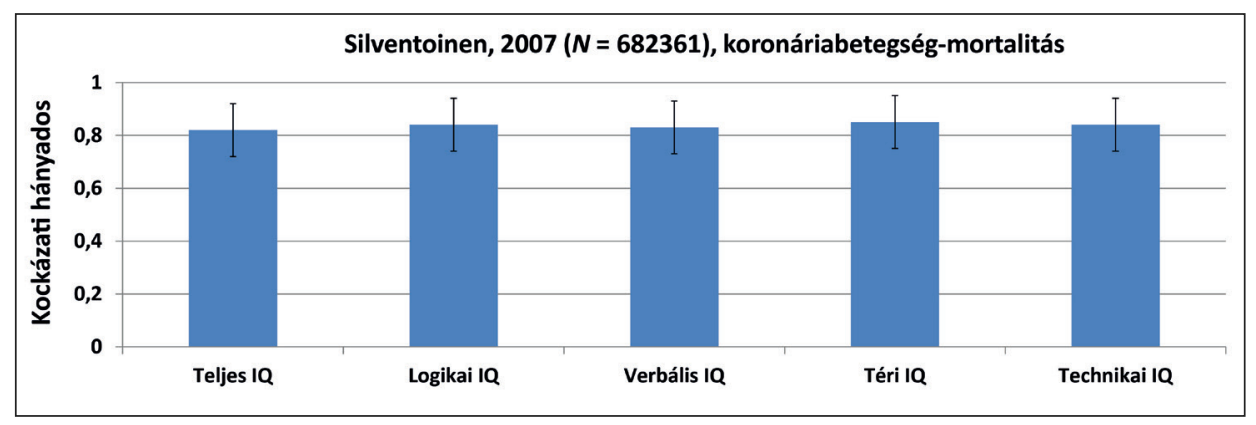

7. ábra. Intelligencia-részképességek és a koronáriabetegség miatt bekövetkező halálozás kockázatának összefüggése Silventoinen és munkatársai (2007) vizsgálata alapján

Megjegyzés: A hibavonalak a hatásméret 95\%-os konfidencia-intervallumát ábrázolják. A hatásméretek polaritása az eredeti vizsgálatnak megfelelő, a negatív kockázati hányadosok utalnak arra, hogy az alacsonyabb intelligencia magasabb egészségügyi kockázattal jár.

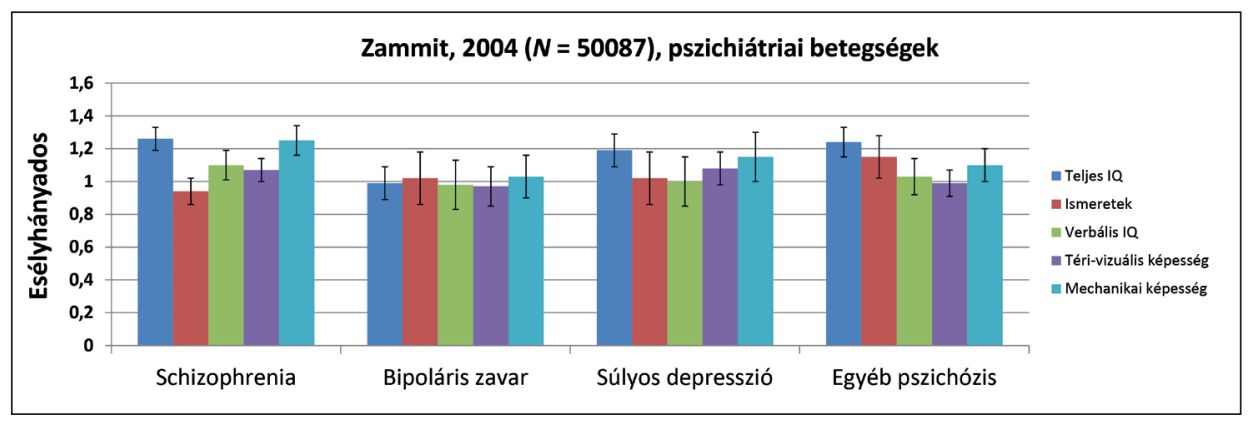

8. ábra. Intelligencia-részképességek és a pszichiátriai hospitalizációs kockázat összefüggése Zammit és munkatársai (2004) vizsgálata alapján

Megjegyzés: A hibavonalak a hatásméret 95\%-os konfidencia-intervallumát ábrázolják. A hatásméretek polaritása az eredeti vizsgálatnak megfelelő, a pozitív kockázati hányadosok utalnak arra, hogy az alacsonyabb intelligencia magasabb egészségügyi kockázattal jár.

\section{Az eredmények összegzése}

A pszichiátriai kognitív epidemiológiai vizsgálatok gyakorlatilag valamenynyi betegség esetében negatív irányú összefüggést találtak az IQ és a betegségkockázat között. A szomatikus kognitív epidemiológiai vizsgálatok eredményei alapján a magasabb premorbid IQ elsősorban a halálozás, a szív- és érrendszeri betegségek, valamint az elhízás alacsonyabb kockázatával függ össze. A légzőszervi megbetegedésekkel és (a dohányzással ösz- 
szefüggő daganatokat leszámítva) a daganatos betegségekkel nem mutatkozik egyértelmú összefüggés. Az eredmények szerint az intelligencia egyes metabolikus betegségek, illetve ritkább vagy kisebb népegészségügyi jelentőségú betegségek ritkább előfordulásával, valamint jobb egészségmagatartással is összefügghet. Az összefüggés - egy-két, jellemzően egyegy vizsgálaton alapuló eredménytől eltekintve - elsősorban negatív irányú, azaz a magasabb intelligencia jobb egészség-magatartással és alacsonyabb betegségkockázattal jár együtt.

Az intelligencia és a pszichiátriai betegségek összefüggését jellemzően egyáltalán nem, vagy csak nagyon kis mértékben módosítja a különböző biológiai és szociodemográfiai tényezőkre - például a születési súlyra vagy a szocioökonómiai státuszra - való statisztikai korrekció. Ez arra utal, hogy ezek nem tekinthetők jelentős mögöttes okoknak vagy mediáló tényezőknek, és az összefüggés okát máshol kell keresnünk. A szomatikus betegségeknél azonban megfigyelhetó, hogy az intelligencia hatását ezek a tényezők - elsősorban a felnőttkori, jellemzően a végzettséggel, a jövedelemmel vagy ezek valamilyen kompozitjával becsült - szocioökonómiai státusz mediálja.

\section{Oki tényezó-e a szocioökonómiai státusz?}

Közismert, hogy az alacsonyabb szocioökonómiai státusz a legtöbb betegség magasabb kockázatával jár: „bár a SES és az egészségi állapot kapcsolatának erőssége sokszor eltéró nagyságú, világosan létezik mind egyetemes egészségügyi ellátást biztosító és nem biztosító országokban, mind orvosi eszközökkel kezelhető és nem kezelhető betegségekkel kapcsolatban, akár szubjektív, akár objektív betegségmutatókat használunk" (Gottfredson, 2004, 181. o.). Nem nehéz hipotéziseket alkotni arról sem, miért: szocioökonómiai státuszunk befolyásolja, mennyire jellemző ránk vagy áll rendelkezésünkre a „társas támogatás, a társas kapcsolatok, a társas szorongás, a krónikus szorongás (allosztatikus teher), a személyes kontroll vagy kompetencia érzése, a kontroll megtapasztalása, az önbizalom, a [jó vagy rossz] táplálkozás, a relatív depriváció, a stigmatizáció, az észlelt [jó vagy rossz] szociális státusz, az ellenálláshoz szükséges erőforrások, a megküzdési stratégiák és az intrinzik problémamegoldó képességek" (Gottfredson, 2004, 182. o.).

Számos, különösen a szomatikus betegségekkel és a halálozással kapcsolatos vizsgálat eredménye, hogy az intelligencia és a későbbi betegségkockázat közötti összefüggést valóban részben vagy egészben a szocioökonómiai státusz valamilyen mutatója - például az iskolai végzettség vagy a jövedelem - mediálja. Más szóval: a vizsgálat első fázisában magasabb IQval rendelkező személyek későbbi jobb egészségét részben az magyarázza, 
hogy - az IQ korrelátumairól szóló ismereteinkkel összhangban - a felnőtt éveikben jobb társadalmi pozícióba kerülnek. Ezek az eredmények egyértelmúen arra utalnak, hogy az IQ hatása a szomatikus egészségre közvetett. Azt azonban nem feltétlenül jelentik, hogy a magasabb jövedelem vagy a magasabb iskolai végzettség közvetlen oki tényező volna. Ennek az az oka, hogy a szocioökonómiai státusz eloszlása a társadalomban nem véletlenszerû́, hanem olyan pszichológiai, biológiai és szociális tényező́k is hatással lehetnek rá, amelyek a későbbi egészségi állapotot is befolyásolják. Például elképzelhető, hogy a szabálykövetó, szorgalmas viselkedésre hajlamosító személyiségjegyek összefüggenek a magasabb IQ-val, de a jobb munkateljesítmény révén - az intelligenciaszinttől függetlenül is - magasabb jövedelemhez, a kedvezőbb egészség-magatartáson keresztül pedig jobb szomatikus egészséghez vezetnek. Ha ez valóban így volna, akkor az elemzésekben azt látnánk, hogy a jövedelemre való statisztikai korrekció csökkenti az IQ és a szomatikus egészség közötti összefüggést: ám a jövedelem hatása szintén közvetett, és egy negyedik tényező, a személyiség hatását tükrözi.

A példában használt személyiségvonásokhoz hasonló potenciális mediáló tényezők sora elvileg végtelen, viszont csak kis részükről áll rendelkezésre mérés a kognitív epidemiológiai kutatásokhoz felhasználható adatbázisokban. Két vizsgálati elrendezés azonban mégis lehetővé teszi a szocioökonómiai státuszt alkotó egyes tényezók közvetlen hatásának mérését.

\subsection{Ikerkontroll-vizsgálatok}

A szocioökonómiai státusz családi halmozódásáért részben genetikai tényezők felelősek. A kvantitatív genetikai vizsgálatok eredményei arra utalnak, hogy a jövedelem (Hyytinen, Ilmakunnas, Johansson, \& Toivanen, 2019) és az iskolai végzettség (Branigan, McCallum, \& Freese, 2013) varianciájának 30-60\%-át genetikai tényezők magyarázzák. A molekuláris genetikai vizsgálatok (Hill és mtsai, 2019; Lee és mtsai, 2018) eredményei mindkét fenotípust konkrét genetikai variánsokhoz is kötötték. Az intelligencia, a szocioökonómiai státusz és a szomatikus egészség genetikailag korreláltak (Hagenaars és mtsai, 2016; Hill és mtsai, 2016), azaz hajlamosító genetikai tényezőik részben átfednek. Emiatt elképzelhető, hogy a szocioökonómiai státusz és a szomatikus egészség közötti összefüggés nem közvetlen, hanem részben vagy egészben genetikai tényezők közvetítik: például a központi idegrendszer vagy az immunrendszer hatékonyabb múködését lehetővé tevő genetikai variánsok egyszerre vezetnek magasabb szocioökonómiai státuszhoz és jobb szomatikus egészséghez, és ez magyarázza a két fenotípus összefüggését (Deary, Harris, \& Hill, 2018). 
A genetikai tényezők valószínúsíthető jelentősége miatt a szocioökonómiai státusz az egészségre gyakorolt közvetlen hatásának egy lehetséges mérése, ha olyan személyek egészségi mutatóit hasonlítjuk össze, akik genetikailag teljesen azonosak, de szocioökonómiai státuszuk különböző: egypetéjú ikrekét. Az ilyen, úgynevezett ikerkontroll-vizsgálatok a genetikai hatások mellett a közös környezet hatását is kontrollálják, a nem közös környezet hatását azonban nem. Az ikerkontroll-vizsgálat ezért elsősorban arra alkalmas, hogy kizárja azt, hogy két fenotípus csak a közös genetikai vagy közös környezeti meghatározók miatt függ össze. Ha például nem maga a magasabb szocioökonómiai státusz, hanem az ahhoz vezetö örökletes vagy a neveltetésból fakadó okokból kialakult tényezők (például a türelmes, munkabíró személyiség) a magasabb jobb egészségi állapot valódi okai, akkor az ikerkontroll-vizsgálatban nem fogunk különbséget látni az egypetéjú ikrek között. Ha azonban ugyanezek a tényezők a nem közös környezet - például az egyéni élettörténet - következtében alakulnak ki, akkor különbség lesz a különböző szocioökonómiai státuszú egypetéjú ikrek egészségi állapotában, annak ellenére, hogy a hatás nem közvetlen.

E kutatási elrendezés limitációi ellenére azonban tény, hogy ha a magasabb szocioökonómiai státusz közvetlen oka a jobb egészségi állapotnak, akkor ennek a hatásnak egypetéjú ikrek összehasonlításánál is meg kell jelennie. Ha a különböző szocioökonómiai státuszú egypetéjú ikrek egészségi állapotában nincs különbség, az arra utal, hogy nem maga a szocioökonómiai státusz, hanem az ahhoz vezetó genetikai (vagy közös környezeti) tényezők a jobb egészségi állapot valós okai.

Egy dán vizsgálatban (Osler, McGue, \& Christensen, 2007) több mint 600 egypetéjú ikerpárnál nem találtak szignifikáns különbséget a párok végzettsége és munkahelye alapján magasabb társadalmi osztályba tartozó tagjánál a fizikai erőben, a kérdőívvel mért depressziós tünetekben, a kognitív képességekben, a fizikai aktivitásban, az alkoholfogyasztásban, a dohányzásban, a zöldség- és gyümölcsfogyasztásban és az önbevallott egészségi állapotban. Egy amerikai vizsgálatban (Krieger, Chen, Coull, \& Selby, 2005) 178 női egypetéjú ikerpárnál nem találtak szignifikáns különbséget az iskolai végzettség függvényében a párok tagjainak vérnyomásában, testtömegindexében, derék-csípő arányában, koleszterin- és vércukorszintjében, fizikai aktivitásában és önbevallott egészségében. Szignifikáns különbségek mutatkoztak azonban a munkahelyi pozíció függvényében. Ha egy ikerpár két tagja közül az egyik alkalmazott volt, a másik pedig vezető vagy vállalkozó, az alkalmazottként dolgozóknak jellemzően magasabb volt a vérnyomása és a koleszterinszintje, ami az eltéró munkavégzés közvetlen egészségi hatására utalhat. Egy másik amerikai vizsgálatban (Fujiwara \& Kawachi, 2009) 351 egypetéjú ikerpárnál viszont csak az önbevallott általános egészségi állapotban találtak szignifikáns különbséget az ikerpárok tagjai között 
az iskolai végzettség függvényében. Az önbevallott fizikai és mentális egészségben, a testtömegindexben, a derékkörfogatban, a derék-csípő arányban, a depressziós tünetekben, a dohányzásban és a fizikai aktivitásban nem volt szignifikáns különbség. Egy amerikai kutatásban (Hamdi, South, \& Krueger, 2016) 81 egypetéjú ikerpár tagjainak összehasonlításánál nem találtak szignifikáns összefüggést az iskolai végzettség és a hét - vér-, vizelet, és kardiológiai vizsgálatból nyert - biomarker alapján becsült allosztatikus teher (a krónikus stresszre adott élettani válasz) között. Egy brit vizsgálatban (Amin, Dunn, \& Spector, 2018) szintén nem találtak egypetéjú ikerpárokon belüli szignifikáns összefüggést az iskolai végzettség és a testtömegindex, valamint az elhízás között. Egy összesen közel 40 ezer fős svéd vizsgálatban (Ericsson, Pedersen, Johansson, Fors, \& Dahl Aslan, 2019) az egypetéjú ikerpárok alacsonyabb iskolai végzettségú tagjainál szignifikánsan magasabb halálozási kockázatot találtak, a foglalkozással becsült felnőttkori és (külön nevelt ikerpároknál) a szülők foglalkozásával becsült gyermekkori társadalmi osztálynak azonban nem volt ilyen hatása. Az alacsony végzettségú és lefelé tartó társadalmi mobilitást mutató (a szülők társadalmi osztályában jellemzőnél alacsonyabb iskolai végzettséget szerző) résztvevők is magasabb halálozási kockázattal rendelkeztek, mint magas végzettségú és felfelé tartó társadalmi mobilitást mutató ikerpárjuk. Egy kicsi, 33 egypetéjú ikerpár adataival dolgozó svéd vizsgálatban (Gatz és mtsai, 2007) viszont a dementia szignifikánsan nagyobb valószínúségét találták az alacsonyabb végzettségú ikernél, egy finn vizsgálatban (Huovinen, Kaprio, Laitinen, \& Koskenvuo, 2001) pedig 262 egypetéjú ikerpárnál a magasabb iskolai végzettséget az asztma védőfaktorának találták, a foglalkozással azonban nem mutattak ki szignifikáns összefüggést.

A pszichiátriai tünetekre vonatkozóan is elérhetőek hasonló ikerkontrollvizsgálatok. Egy nagy amerikai vizsgálatban (Halpern-Manners, Schnabel, Hernandez, Silberg, \& Eaves, 2016) a Virginia 30000 adatbázis 2019 ikerpárjánál a depressziós, fóbiás vagy pániktünetek és a szomatizációs tünetek gyakorisága ikerpárokon belül - szemben a teljes mintában láthatónál nem függtek össze az iskolai végzettséggel. Egy másik amerikai vizsgálatban (Cohen-Cline és mtsai, 2018) több mint 5000 egypetéjú ikerpárnál nem találtak szignifikáns összefüggést a lakóhely szociális deprivációs indexe és a depressziós tünetek között.

Kétpetéjú ikerpárokon belül - ahol van szabad genetikai variancia - többnyire megfigyelhetőek a teljes populációra jellemző összefüggések a szocioökonómiai státusz és az egészségi mutatók között (Cohen-Cline és mtsai, 2018; Lam, Tyler, Scurrah, Reavley, \& Dite, 2019; Osler és mtsai, 2007).

Ezek az ikerkontroll-vizsgálatok összességében arra utalnak, hogy többnyire (de nem kivétel nélkül) nem maga a szocioökonómiai státusz, hanem annak genetikai és közös környezeti determinánsai vezetnek jobb egészségi állapothoz. 


\subsection{Pszeudo-experimentális vizsgálatok}

Az embereken végzett kísérleteket szigorú etikai normák és törvények szabályozzák vagy tiltják. A gyakorlatban azonban időnként mégis történnek olyan társadalmi változások, amelyek véletlenszerúségük miatt egyfajta kísérletként értelmezhetőek. A tankötelezettségi korhatár egy adott évtől érvényes megemelése például az iskolai végzettségbe való kísérletes beavatkozásnak tekinthető, és hatása az úgynevezett pszeudo-experimentális vizsgálatokban elemezhető. Mivel az egészségi állapotot befolyásoló többi tényező - például az orvostudomány fejlődése vagy a lakosság átalakuló szokásai feltehetően nem változott különösebben sokat az oktatási reform évében, ha a magasabb iskolai végzettség közvetlenül jobb egészségi állapothoz vezet, akkor a lakosság egészségi állapotának trendjében a reform évéhez köthetó törést várunk. Más szavakkal: ha a később született korosztályok minden évben egyre egészségesebbek is, az oktatás valós oki hatása esetén ez a különbség kiugrik az átlagból azoknál, akik az oktatási reform miatt mintegy véletlenül több évnyi iskolázást kaptak, mint az előttük mindössze egy évvel születettek.

Nagy-Britanniában 1947-ben 14-ról 15 évre, 1972-ben pedig 15-ról 16 évre emelték a tankötelezettség korhatárát. Ezeknek a reformoknak a hatását két pszeudo-experimentális vizsgálatban elemezték. Clark és Royer (2010) egy úgynevezett regresszió-diszkontinuitásos elemzésben úgy találta, hogy az oktatási reformok minimális hatással voltak a lakosság egészségi állapotára. Az 1947-es reform 3,59 ezrelékponttal csökkentette a 45-69 éves lakosság 190 ezrelék körüli halálozási rátáját, ezen belül 0,34 ezrelékponttal a légzési, 0,85 ezrelékponttal a keringéses és 0,55 ezrelékponttal az egyéb halálozási rátát. Az 1972-es reform a 20-44 éves - ne felejtsük el, hogy ez a reform később történt, ezért még nem idősek, akik ennek idején jártak iskolába - lakosság 23 ezrelék körüli éves halálozási rátáját 0,28 ezrelékponttal csökkentette. Az 1947-es reform hatására 0,08\%-kal, az 1972-es hatására 0,04\%-kal kevesebben tartották egészségüket „elfogadhatónak” vagy „rossznak” egy kérdőívben, míg az 1947-es reform hatására körülbelül 1\%-kal kevesebben, az 1972-es hatására viszont 0,8\%-kal többen dohányoztak. Ezek az eredmények többnyire nem voltak statisztikailag szignifikánsak. Az 1972-es reform egy újabb, a Brit Biobank több mint 300000 résztvevőjének adatai alapján végzett elemzésének eredményei szerint szintén szerény, de valós hatással volt számos egészségi mutatóra (Davies, Dickson, Davey Smith, Windmeijer, \& van den Berg, 2018). Akik a reform következtében egy évvel tovább jártak iskolába, azok 1-4\%-kal ritkábban szenvedtek magas vérnyomástól, diabétesztől, agyvérzéstől, szívrohamtól és depressziótól - egyedül a daganatos betegségekre nem volt érdemi hatás. A reformban érintettek teljes mortalitása körülbelül 1\%-kal csökkent, közel 5\%-kal ritkábban dohányoztak a megkérdezésük pillanatában és 10\%-kal ritkábban dohányoztak 
valaha, emellett körülbelül 1 egységgel $\left(\mathrm{kg} / \mathrm{m}^{2}\right)$ alacsonyabb volt a testtömegindexük, körülbelül napi húsz perccel kevesebbet néztek tévét és valamivel gyakrabban végeztek mérsékelt intenzitású testmozgást, viszont minimálisan gyakrabban fogyasztottak alkoholt és fél-másfél higanymilliméterrel magasabb volt a vérnyomásuk.

\section{Genetikai okok}

A pszeudo-experimentális és részben az ikerkontroll-vizsgálatok a felnőttkori szocioökonómiai státusz egy fontos elemének - az iskolai végzettségnek - csak szerény oki hatását találták az egészségi állapotra. Valószínú, hogy a magasabb intelligencia és a jobb szomatikus és mentális egészség közötti kapcsolatot részben genetikai mediáló tényezők vagy mögöttes okok magyarázzák (Deary és mtsai, 2018; Hill, Harris, \& Deary, 2019).

Az utóbbi évtized jelentős áttörést hozott a pszichometriai intelligencia genetikai meghatározóinak vizsgálatában (Plomin, 2018; Plomin \& von Stumm, 2018; Ujma, 2019). Ezek a vizsgálatok nemcsak feltárták az intelligencia genetikai korrelátumainak egy részét, de megerősítették azt is, hogy az intelligencia, valamint a szomatikus és mentális egészség genetikailag korrelált. A genetikai korreláció a genetikai okok átfedését jelenti: -0,5-ös genetikai korreláció az IQ és egy betegségkockázat között például azt jelenti, hogy az átlagnál 1 szórással magasabb genetikai hajlam a magasabb intelligenciára egyben a betegség kockázatára való, az átlagnál 0,5 szórással alacsonyabb hajlamot is jelent. A 6 . táblázat az intelligencia és egyes egészségmutatók közötti genetikai korrelációkat összegzi az intelligenciára vonatkozó egyik legnagyobb teljesgenom-asszociációs vizsgálat (Savage és mtsai, 2018) eredményei alapján.

6. táblázat. Az intelligencia és válogatott fenotípusok közötti genetikai korreláció (rg) Savage és munkatársai (2018) eredményei alapján

\begin{tabular}{|l|c|}
\hline \multicolumn{1}{|c|}{ Fenotípus } & $r_{\mathrm{g}}$ \\
\hline Figyelemhiányos hiperaktivitás-zavar (ADHD) & $-0,36$ \\
\hline Alzheimer-kór & $-0,27$ \\
\hline Depresszív tünetek & $-0,27$ \\
\hline Gyermekek száma & $-0,21$ \\
\hline Schizophrenia & $-0,21$ \\
\hline Neuroticizmus & $-0,21$ \\
\hline Koronáriabetegség & $-0,19$ \\
\hline
\end{tabular}




\begin{tabular}{|l|c|}
\hline \multicolumn{1}{|c|}{ Fenotípus } & $r_{\mathrm{g}}$ \\
\hline Dohányzik/dohányzott & $-0,14$ \\
\hline Testtömegindex & $-0,11$ \\
\hline Derékkörfogat & $-0,10$ \\
\hline Cigaretta/nap & $-0,08$ \\
\hline Gyermekkori elhízás & $-0,08$ \\
\hline Bipoláris zavar & $-0,06$ \\
\hline 2-es típusú cukorbetegség & $-0,04$ \\
\hline Gyermekkori testtömegindex & $-0,03$ \\
\hline Anorexia nervosa & 0,07 \\
\hline Autizmus & 0,25 \\
\hline Leszokott a dohányzásról & 0,33 \\
\hline Várható élettartam & 0,43 \\
\hline Életkor az első szüléskor & 0,47 \\
\hline Iskolai végzettség & 0,71 \\
\hline
\end{tabular}

Ezek a genetikai korrelációk leegyszerüsítve háromféle hatás valamelyikét (vagy kombinációját) jelezhetik (Deary és mtsai, 2018): 1. a genetikai variánsok jobb egészséghez, ez pedig magasabb intelligenciához vezet; 2. a genetikai variánsok magasabb intelligenciához, ez pedig jobb egészséghez vezet; valamint 3. a két fenotípus hátterében közös, egyfajta "testi rendszerintegritás" (Deary, 2012), azaz a test és az idegrendszer optimális múködését meghatározó genetikai variánsok állnak¹.

Pleiotrópiának nevezzük, ha egy genetikai variáns több fenotípusra is hatással van. Az 1. és 2 . hatás úgynevezett mediált pleiotrópia: a genetikai variánsok biológiai hatása a testi egészséget (1.) vagy az intelligenciát (2.) befolyásolja, a másik fenotípus ennek a következménye, talán csak további közvetítőkön (például az immunrendszer felszabadult kapacitásain vagy a magasabb intelligencia miatt követett egészségesebb életmódon) keresztül.

${ }^{1}$ Fontos megjegyezni, hogy a genetikai korrelációkat adó vizsgálatokat - a klasszikus kognitív epidemiológiai vizsgálatokkal ellentétben - keresztmetszeti mintán végezték, azaz nem álltak rendelkezésre ugyanazon személyektől adatok a korábbi intelligenciáról és a későbbi egészségi állapotról. A klasszikus kognitív epidemiológiai vizsgálatokban látott hatásokat az időbeli elrendezés miatt az 1. hatás csak akkor magyarázhatja, ha a genetikai kockázati tényező hatása már az IQ-teszt mérése előtt fennállt. 
A 3. hatás úgynevezett biológiai pleiotrópia: a genetikai hatások közvetlen biológiai hatással vannak mindkét fenotípusra. Genetikai statisztikai módszerek - elsősorban az úgynevezett mendeli randomizáció - segíthetnek feltárni, hogy a genetikai korrelációk a három lehetőség közül pontosan melyiket tükrözik (Deary és mtsai, 2018).

A mendeli randomizáció a teljesgenom-asszociációs vizsgálatokban egy fenotípussal összefüggő genetikai variánsokat úgynevezett instrumentális változóként használva teszteli, összefüggenek-e egy másik fenotípus jelenlétével is, majd ezt az elemzést a fenotípusokat felcserélve is megismétli. Egyszerúbben szólva: akinek több van például az IQ-val összefüggő genetikai variánsokból, az ritkábban lesz-e cukorbeteg? És akinek a cukorbetegséggel összefüggő genetikai variánsokból van több, annak alacsonyabb-e az IQ-ja? Mivel a genetikai variánsok megváltoztathatják a fenotípust, de a fenotípusok a genetikai variánsokat nem, az aszimmetrikus összefüggés segít feltárni a genetikai korreláció hátterében lévő ok-okozati viszonyokat. Például ha az IQ-val összefüggó genetikai variánsok a cukorbetegség alacsonyabb kockázatával járnak együtt, de a cukorbetegség alacsonyabb kockázatával járó variánsok nem járnak együtt magasabb IQ-val, az arra utal, hogy a helyes kauzális út a következő: genetikai variánsok $\rightarrow$ IQ $\rightarrow$ cukorbetegség-kockázat. Ezt a hipotetikus eredményt magyarázhatja, ha az örökletesen intelligensebb személyek tudatosabban kerülik a cukorbetegséghez vezetó életmódot, viszont a cukorbetegségre örökletesen hajlamos emberek a betegségük miatt nem szenvednek intelligencia-deficitet.

A jelenleg rendelkezésre álló mendeli randomizációs vizsgálatok eredményei egyelőre nem tárták fel konkluzívan az egészség és az intelligencia genetikai hátterének összefüggését. Savage és munkatársai (2018) kétirányú kapcsolatot találtak az intelligencia és a schizophrenia kockázata között, továbbá, míg az intelligencia egyirányú védőfaktor volt az ADHD és az Alzheimer-kór ellen, addig az autizmus spektrum zavar szempontjából kockázati faktornak bizonyult. Anderson és munkatársai (2020) mind az intelligenciát, mind az iskolai végzettséget védőfaktornak találták az Alzheimerkór ellen, bár az iskolai végzettség hatását elsősorban az intelligencia mediálta. Davies és munkatársai (2019) az intelligencia hatását találták a magasabb szorítóerőre, a testmagasságra, az alkoholfogyasztásra, a testmozgásra, valamint az alacsonyabb testtömegindexre, vérnyomásra és ritkább tv-nézésre. Adams (2020) az intelligenciát védőfaktornak találta a schizophrenia ellen. Hagenaars, Gale, Deary és Harris (2017) viszont semmilyen oki hatást nem találtak sem az egészségmutatóktól az intelligencia, sem pedig az iskolai végzettségtól az egészségmutatók felé. Az eredmények bizonytalansága valószínúleg leginkább a használt genetikai variánsok minőségével kapcsolatos problémákra vezethető vissza. A teljesgenomasszociációs vizsgálatok nem tárják fel a vizsgált fenotípus teljes genetikai 
hátterét: a mendeli randomizációs vizsgálatokban jellemzően csak néhány, a fenotipikus variancia legfeljebb néhány százalékát magyarázó egypontos nukleotid-polimorfizmust (single-nucleotide polymorphism, SNP) használnak. A pontosabb teljesgenom-asszociációs vizsgálatok és a genetikai statisztika fejlődése várhatóan megbízhatóbb, az ok-okozati viszonyokra vonatkozó következtetések levonására alkalmas vizsgálatokat tesz majd lehetővé.

\section{Az intelligencia gyakorlati jelentősége az egészségmegőrzésben}

A magasabb szocioökonómiai státusz elérésének elősegítésén és a genetikailag közvetített hatásokon túl a magasabb intelligenciaszint nagyon közvetlen és gyakorlati szereppel is bírhat az egészség megőrzésében és a korai halálozás elkerülésében (Gottfredson, 2004). Az intelligensebb személyeknek jobb az egészségértése (health literacy), könnyebben megértik egészségmagatartásuk hosszú távú következményeit, motiváltabbak és jobban képesek az egészségüket hosszú távon is fenntartó életmódot folytatni, ha pedig betegek lesznek, jobban megértik az orvosi instrukciókat és azt, hogy miért és hogyan kell követniük ezeket. Ez utóbbi a magas vérnyomáshoz vagy a cukorbetegséghez hasonló gyakori, de összetett és tartós kezelést igénylő betegségek esetében különösen fontos. A balesetek és sérülések megelőzése egy további terület, ahol a magas intelligencia előnyt jelent (Batty és mtsai, 2009): az intelligensebb személy képes lehet felismerni és elkerülni a kockázatos viselkedéseket vagy a veszélyes helyeket és helyzeteket, ha pedig megtörtént a baj, kompetensebb módon tudja csökkenteni a károkat.

Az ilyen gyakorlati okok biztosan fontos szerepet játszanak az intelligencia és az egészségi állapot összefüggésében, és az intelligencia jelentős közvetlen hatása arra utal, hogy fontos kiegészítői vagy akár teljes mértékben a közvetítői a szocioökonómiai státusz hatásának. Valószínúleg a genetikai összefüggések jelentős része is innen származik: genetikai okok jelentős hatással vannak az intelligencia egyéni különbségeire (Plomin \& Deary, 2015; Plomin \& von Stumm, 2018; Ujma, 2019), ezek pedig az egészség-magatartás megváltoztatásán keresztül - a genetikai vizsgálatok logikája szerint mediált pleiotrópiával - hatással vannak az egészségi állapotra.

\section{9. Összegzés}

A magasabb premorbid intelligencia szinte valamennyi szomatikus és pszichiátriai betegség megjelenésének alacsonyabb kockázatát vetíti előre. Ezt az összefüggést a szomatikus betegségek esetében jobban, a pszichiátriai 
betegségek esetében kevésbé mediálja a felnőttkori szocioökonómiai státusz. A rendelkezésre álló adatok alapján a gyermekkori szocioökonómiai státusz mögöttes okként csak kevéssé befolyásolja az összefüggést.

A felnőttkori szocioökonómiai státusz az ikerkontroll-vizsgálatok és a pszeudo-experimentális vizsgálatok eredményei alapján azonban csak minimális oki hatással van a jobb szomatikus egészségre. A genetikai vizsgálatok eredményei arra utalnak, hogy az intelligencia és a jobb egészség közötti összefüggés részben a két fenotípus átfedő genetikai hátteréből ered. A genetikai hatások pontos mechanizmusa azonban egyelőre nem pontosan feltárt. Az intelligencia egyik legfontosabb, az egészségi állapottal átfedő genetikai hátteret is megmagyarázó szerepe az lehet, hogy elósegíti az egészséggel és az egészség-magatartás hosszú távú következményeivel kapcsolatos ismeretek, valamint az orvosi instrukciók megértését, lehetővé téve a kedvezőbb egészség-magatartást és a felmerülő betegségek hatékonyabb kezelését.

\section{Irodalom}

Adams, C.D. (2020). A multivariable Mendelian randomization to appraise the pleiotropy between intelligence, education, and bipolar disorder in relation to schizophrenia. Scientific Reports, 10(1), 6018. DOI: 10.1038/s41598-020-63104-6

Agnew-Blais, J.C., Buka, S.L., Fitzmaurice, G.M., Smoller, J.W., Goldstein, J.M., \& Seidman, L.J. (2015). Early childhood IQ trajectories in individuals later developing schizophrenia and affective psychoses in the New England Family Studies. Schizophrenia bulletin, 41(4), 817-823.

Alati, R., Gunnell, D., Najman, J., Williams, G., \& Lawlor, D. (2009). Is IQ in childhood associated with suicidal thoughts and attempts? Findings from the Mater University Study of Pregnancy and its outcomes. Suicide and Life-Threatening Behavior, 39(3), 282-293.

Albee, G.W., Lane, E.A., \& Reuter, J.M. (1964). Childhood intelligence of future schizophrenics and neighborhood Peers. The Journal of Psychology, 58(1), 141-144.

Amin, V., Dunn, P., \& Spector, T. (2018). Does education attenuate the genetic risk of obesity? Evidence from U.K. Twins. Economics \& Human Biology, 31, 200-208.

Anderson, E.L., Howe, L.D., Wade, K.H., Ben-Shlomo, Y., Hill, W.D., Deary, I.J., et al. (2020). Education, intelligence and Alzheimer's disease: evidence from a multivariable twosample Mendelian randomization study. International Journal of Epidemiology, 49(4), 1163-1172.

Bain, G.H., Lemmon, H., Teunisse, S., Starr, J.M., Fox, H.C., Deary, I.J., \& Whalley, L.J. (2003). Quality of Life in healthy old age: relationships with childhood IQ, minor psychological symptoms and optimism. Social Psychiatry and Psychiatric Epidemiology, 38(11), 632-636.

Batty, G., Gale, C., Mortensen, L.H., Langenberg, C., Shipley, M., \& Deary, I. (2008). Premorbid intelligence, the metabolic syndrome and mortality: the Vietnam Experience Study. Diabetologia, 51(3), 436-443.

Batty, G.D., Deary, I.J., \& Macintyre, S. (2006). Childhood IQ and life course socioeconomic position in relation to alcohol induced hangovers in adulthood: the Aberdeen children of the 1950s study. Journal of Epidemiology and Community Health, 60(10), 872-874. 
Batty, G.D., Deary, I.J., \& Macintyre, S. (2007). Childhood IQ in relation to risk factors for premature mortality in middle-aged persons: the Aberdeen Children of the 1950s study. Journal of Epidemiology and Community Health, 61(3), 241-249.

Batty, G.D., Deary, I.J., Tengstrom, A., \& Rasmussen, F. (2018). IQ in early adulthood and later risk of death by homicide: cohort study of 1 million men. British Journal of Psychiatry, 193(6), 461-465.

Batty, G.D., Gale, C.R., Tynelius, P., Deary, I.J., \& Rasmussen, F. (2009). IQ in early adulthood, socioeconomic position, and unintentional injury mortality by middle age: a cohort study of more than 1 million Swedish men. American Journal of Epidemiology, 169(5), 606-615.

Batty, G.D., Mortensen, L.H., Gale, C.R., Shipley, M.J., Roberts, B.A., \& Deary, I.J. (2009). IQ in late adolescence/early adulthood, risk factors in middle age, and later cancer mortality in men: the Vietnam Experience Study. Psycho-Oncology, 18(10), 1122-1126.

Batty, G.D., Wennerstad, K.M., Smith, G.D., Gunnell, D., Deary, I.J., Tynelius, P., \& Rasmussen, F. (2007). IQ in early adulthood and later cancer risk: cohort study of one million Swedish men. Annals of Oncology, 18(1), 21-28.

Batty, G.D., Wennerstad, K.M., Smith, G.D., Gunnell, D., Deary, I.J., Tynelius, P., \& Rasmussen, F. (2009). IQ in early adulthood and mortality by middle age: cohort study of 1 million Swedish men. Epidemiology, 20(1), 100-109.

Batty, G.D., Whitley, E., Deary, I.J., Gale, C.R., Tynelius, P., \& Rasmussen, F. (2010). Psychosis alters association between IQ and future risk of attempted suicide: cohort study of 1109475 Swedish men. British Medical Journal, 340, c2506. DOI: 10.1136/bmj.c2506

Branigan, A.R., McCallum, K.J., \& Freese, J. (2013). Variation in the heritability of educational attainment: an international meta-analysis. Social forces, 92(1), 109-140.

Calvin, C.M., Batty, G.D., Der, G., Brett, C.E., Taylor, A., Pattie, A., et al. (2017). Childhood intelligence in relation to major causes of death in 68 year follow-up: prospective population study. British Medical Journal, 357. DOI: 10.1136/bmj.j2708

Calvin, C.M., Deary, I.J., Fenton, C., Roberts, B.A., Der, G., Leckenby, N., \& Batty, G.D. (2011). Intelligence in youth and all-cause-mortality: systematic review with metaanalysis. International Journal of Epidemiology, 40(3), 626-644.

Chandola, T., Deary, I.J., Blane, D., \& Batty, G.D. (2006). Childhood IQ in relation to obesity and weight gain in adult life: the National Child Development (1958) Study. International Journal Of Obesity, 30, 1422. DOI: 10.1038/ sj.ijo.0803279

Chang, S.S., Chen, Y.Y., Heron, J., Kidger, J., Lewis, G., \& Gunnell, D. (2014). IQ and adolescent self-harm behaviours in the ALSPAC birth cohort. Journal of Affectitve Disorders, 152-154, 175-182.

Clark, D., \& Royer, H. (2010). The effect of education on adult health and mortality: Evidence from Britain. American Economic Review, 103(6), 2087-2120.

Cohen-Cline, H., Beresford, S.A.A., Barrington, W.E., Matsueda, R.L., Wakefield, J., \& Duncan, G.E. (2018). Associations between neighbourhood characteristics and depression: a twin study. Journal of Epidemiology and Community Health, 72(3), 202-207.

Corley, J., Crang, J.A., \& Deary, I.J. (2009). Childhood IQ and in-service mortality in Scottish Army personnel during World War II. Intelligence, 37(3), 238-242. DOI: https://doi. org/10.1016/j.intell.2008.11.003

Čukić, I., Brett, C.E., Calvin, C.M., Batty, G.D., \& Deary, I.J. (2017). Childhood IQ and survival to 79: Follow-up of $94 \%$ of the Scottish Mental Survey 1947. Intelligence, 63, 45-50.

Davies, N.M., Dickson, M., Davey Smith, G., Windmeijer, F., \& van den Berg, G.J. (2018). The effect of education on adult mortality, health, and income: triangulating across genetic and policy reforms. bioRxiv, 250068. DOI: 10.1101/250068 
Davies, N.M., Hill, W.D., Anderson, E.L., Sanderson, E., Deary, I.J., \& Davey Smith, G. (2019). Multivariable two-sample Mendelian randomization estimates of the effects of intelligence and education on health. eLife, 8, e43990. DOI: 10.7554/eLife.43990

Deary, I.J. (2012). Looking for 'System Integrity' in cognitive epidemiology. Gerontology, $58(6), 545-553$.

Deary, I.J., \& Batty, G.D. (2007). Cognitive epidemiology. Journal of Epidemiology and Community Health, 61(5), 378-384.

Deary, I.J., Harris, S.E., \& Hill, W.D. (2018). What genome-wide association studies reveal about the association between intelligence and physical health, illness, and mortality. Current Opinion in Psychology, 27, 6-12.

Deary, I.J., Pattie, A., \& Starr, J.M. (2013). The stability of intelligence from age 11 to age 90 years: the Lothian birth cohort of 1921. Psychological Science, 24(12), 2361-2368.

Deary, I.J., Whiteman, M.C., Starr, J.M., Whalley, L.J., \& Fox, H.C. (2004). The Impact of Childhood Intelligence on Later Life: Following Up the Scottish Mental Surveys of 1932 and 1947. Journal of Personality and Social Psychology, 86(1), 130-147.

Der, G., Batty, G.D., \& Deary, I.J. (2009). The association between IQ in adolescence and a range of health outcomes at 40 in the 1979 US National Longitudinal Study of Youth. Intelligence, 37(6), 573-580.

Ericsson, M., Pedersen, N.L., Johansson, A.L.V., Fors, S., \& Dahl Aslan, A.K. (2019). Lifecourse socioeconomic differences and social mobility in preventable and non-preventable mortality: a study of Swedish twins. International Journal of Epidemiology, 48(5), 1701-1709.

Floyd, R.G., Reynolds, M.R., Farmer, R.L., \& Kranzler, J.H. (2013). Are the general factors from different child and adolescent intelligence tests the same? Results from a fivesample, six-test analysis. School Psychology Review, 42(4), 383-401.

Fujiwara, T., \& Kawachi, I. (2009). Is education causally related to better health? A twin fixed-effect study in the USA. International Journal of Epidemiology, 38(5), 1310-1322.

Gale, C.R., Batty, G.D., McIntosh, A.M., Porteous, D.J., Deary, I.J., \& Rasmussen, F. (2013). Is bipolar disorder more common in highly intelligent people? A cohort study of a million men. Molecular Psychiatry, 18(2), 190-194.

Gale, C.R., Batty, G.D., Tynelius, P., Deary, I.J., \& Rasmussen, F. (2010). Intelligence in early adulthood and subsequent hospitalization for mental disorders. Epidemiology (Cambridge, Mass.), 21(1), 70-77.

Gale, C.R., Deary, I.J., Boyle, S.H., Barefoot, J., Mortensen, L.H., \& Batty, G.D. (2008). Cognitive ability in early adulthood and risk of 5 specific psychiatric disorders in middle age: the Vietnam experience study. Archives of General Psychiatry, 65(12), 1410-1418.

Gale, C.R., Hatch, S.L., Batty, G.D., \& Deary, I.J. (2009). Intelligence in childhood and risk of psychological distress in adulthood: The 1958 National Child Development Survey and the 1970 British Cohort Study. Intelligence, 37(6), 592-599.

Gatz, M., Mortimer, J.A., Fratiglioni, L., Johansson, B., Berg, S., Andel, R., et al. (2007). Accounting for the relationship between low education and dementia: a twin study. Physiology \& behavior, 92(1-2), 232-237.

Gibbons, A., \& Warne, R.T. (2019). First publication of subtests in the Stanford-Binet 5, WAIS-IV, WISC-V, and WPPSI-IV. Intelligence, 75, 9-18.

Glaser, B., Gunnell, D., Timpson, N., Joinson, C., Zammit, S., Smith, G.D., \& Lewis, G. (2011). Age- and puberty-dependent association between IQ score in early childhood and depressive symptoms in adolescence. Psychological Medicine, 41(2), 333-343.

Gottfredson, L.S. (2004). Intelligence: is it the epidemiologists' elusive „fundamental cause” of social class inequalities in health? Journal of Personality and Social Psychology, 86(1), 174-199. 
Gow, A.J., Johnson, W., Pattie, A., Brett, C.E., Roberts, B., Starr, J.M., \& Deary, I.J. (2011). Stability and change in intelligence from age 11 to ages 70, 79, and 87: The Lothian Birth Cohorts of 1921 and 1936. Psychology and Aging, 26(1), 232-240.

Gregory, H. (2015). McNamara's Folly: The Use of Low-IQ Troops in the Vietnam War. W. Conshohocken, PA: Infinity Publishing

Hagenaars, S.P., Gale, C.R., Deary, I.J., \& Harris, S.E. (2017). Cognitive ability and physical health: a Mendelian randomization study. Scientific Reports, 7(1), 2651. DOI: 10.1038/ s41598-017-02837-3

Hagenaars, S.P., Harris, S.E., Davies, G., Hill, W.D., Liewald, D.C.M., Ritchie, S.J., et al. (2016). Shared genetic aetiology between cognitive functions and physical and mental health in UK Biobank ( $=112$ [thinsp]151) and 24 GWAS consortia. Molecular Psychiatry, 21(11), 1624-1632.

Halpern-Manners, A., Schnabel, L., Hernandez, E.M., Silberg, J.L., \& Eaves, L.J. (2016). The relationship between education and mental health: new evidence from a discordant twin study. Social Forces, 95(1), 107-131.

Hamdi, N.R., South, S.C., \& Krueger, R.F. (2016). Does education lower allostatic load? A co-twin control study. Brain, Behavior, and Immunity, 56, 221-229.

Hatch, S.L., Jones, P.B., Kuh, D., Hardy, R., Wadsworth, M.E., \& Richards, M. (2007). Childhood cognitive ability and adult mental health in the British 1946 birth cohort. Social Science \& Medicine, 64(11), 2285-2296.

Hegelund, E.R., Flensborg-Madsen, T., Dammeyer, J., \& Mortensen, E.L. (2018). Low IQ as a predictor of unsuccessful educational and occupational achievement: A register-based study of 1,098,742 men in Denmark 1968-2016. Intelligence, 71, 46-53.

Hegelund, E.R., Flensborg-Madsen, T., Dammeyer, J., Mortensen, L.H., \& Mortensen, E.L. (2019). The influence of familial factors on the association between IQ and educational and occupational achievement: A sibling approach. Personality and Individual Differences, $149,100-107$.

Herrnstein, R.J., \& Murray, C. (2010). The Bell Curve: Intelligence and Class Structure in American Life. New York, NY: Free Press

Hill, W.D., Davies, N.M., Ritchie, S.J., Skene, N.G., Bryois, J., Bell, S., et al. (2019). Genomewide analysis identifies molecular systems and 149 genetic loci associated with income. Nature Communications, 10(1), 5741. DOI: 10.1038/s41467-019-13585-5

Hill, W.D., Hagenaars, S.P., Marioni, R.E., Harris, S.E., Liewald, D.C., Davies, G., et al. (2016). Molecular genetic contributions to social deprivation and household income in UK Biobank. Current Biology, 26(22), 3083-3089.

Hill, W.D., Harris, S.E., \& Deary, I.J. (2019). What genome-wide association studies reveal about the association between intelligence and mental health. Current Opinion in Psychology, 27, 25-30.

Huovinen, E., Kaprio, J., Laitinen, L.A., \& Koskenvuo, M. (2001). Social predictors of adult asthma: a co-twin case-control study. Thorax, 56(3), 234-236.

Hyytinen, A., Ilmakunnas, P., Johansson, E., \& Toivanen, O. (2019). Heritability of lifetime earnings. The Journal of Economic Inequality, 17, 319-335.

Jensen, A.R. (1980). Bias in Mental Testing. New York, NY: Free Press

Johnson, W., Bouchard, T.J., Krueger, R.F., McGue, M., \& Gottesman, I.I. (2004). Just one g: consistent results from three test batteries. Intelligence, 32(1), 95-107.

Johnson, W., Nijenhuis, J.T., \& Bouchard, T.J. (2008). Still just 1 g: Consistent results from five test batteries. Intelligence, 36(1), 81-95.

Kaufman, J.C. (2014). Creativity and Mental Illness: Cambridge: Cambridge University Press 
Kendler, K.S., Ohlsson, H., Keefe, R.S.E., Sundquist, K., \& Sundquist, J. (2017). The joint impact of cognitive performance in adolescence and familial cognitive aptitude on risk for major psychiatric disorders: a delineation of four potential pathways to illness. Molecular Psychiatry, 23, 1076-1083.

Kendler, K.S., Ohlsson, H., Sundquist, J., \& Sundquist, K. (2015). IQ and schizophrenia in a Swedish national sample: their causal relationship and the interaction of IQ with genetic risk. The American Journal of Psychiatry, 172(3), 259-265.

Keyes, K.M., Platt, J., Kaufman, A.S., \& McLaughlin, K.A. (2017). Association of fluid intelligence and psychiatric disorders in a population-representative sample of US adolescents. JAMA Psychiatry, 74(2), 179-188.

Khandaker, G.M., Barnett, J.H., White, I.R., \& Jones, P.B. (2011). A quantitative meta-analysis of population-based studies of premorbid intelligence and schizophrenia. Schizophrenia Research, 132(2-3), 220-227.

Khandaker, G.M., Stochl, J., Zammit, S., Goodyer, I., Lewis, G., \& Jones, P.B. (2018). Childhood inflammatory markers and intelligence as predictors of subsequent persistent depressive symptoms: a longitudinal cohort study. Psychological Medicine, 48(9), 15141522.

Koenen, K.C., Moffitt, T.E., Poulton, R., Martin, J., \& Caspi, A. (2007). Early childhood factors associated with the development of post-traumatic stress disorder: results from a longitudinal birth cohort. Psychological Medicine, 37(2), 181-192.

Koenen, K.C., Moffitt, T.E., Roberts, A.L., Martin, L.T., Kubzansky, L., Harrington, H., et al. (2009). Childhood IQ and adult mental disorders: a test of the cognitive reserve hypothesis. The American Journal of Psychiatry, 166(1), 50-57.

Krieger, N., Chen, J.T., Coull, B.A., \& Selby, J.V. (2005). Lifetime socioeconomic position and twins' health: an analysis of 308 pairs of United States women twins. PLoS Medicine, 2(7), e162-e162. DOI: 10.1371/journal.pmed.0020162

Lam, J.R., Tyler, J., Scurrah, K.J., Reavley, N.J., \& Dite, G.S. (2019). The association between socioeconomic Status and psychological distress: a within and between twin study. Twin Research and Human Genetics, 22(5), 312-320.

Lane, E.A., \& Albee, G.W. (1968). On childhood intellectual decline of adult schizophrenics: a reassessment of an earlier study. Journal of Abnormal Psychology, 73(2), 174-177.

Larsen, L., Hartmann, P., \& Nyborg, H. (2008). The stability of general intelligence from early adulthood to middle-age. Intelligence, 36(1), 29-34.

Lawlor, D.A., Batty, G.D., Clark, H., McIntyre, S., \& Leon, D.A. (2008). Association of childhood intelligence with risk of coronary heart disease and stroke: findings from the Aberdeen Children of the 1950s cohort study. European Journal of Epidemiology, 23(10), 695-706.

Lee, J.J., Wedow, R., Okbay, A., Kong, E., Maghzian, O., Zacher, M., et al. (2018). Gene discovery and polygenic prediction from a genome-wide association study of educational attainment in 1.1 million individuals. Nature genetics, 50(8) 1112-1121.

Lyons, M.J., York, T.P., Franz, C.E., Grant, M.D., Eaves, L.J., Jacobson, K.C., et al. (2009). Genes determine stability and the environment determines change in cognitive ability during 35 years of adulthood. Psychological Science, 20(9), 1146-1152.

Major, J.T., Johnson, W., \& Bouchard, T.J. (2011). The dependability of the general factor of intelligence: Why small, single-factor models do not adequately represent g. Intelligence, 39(5), 418-433.

Martin, L.T., \& Kubzansky, L.D. (2005). Childhood cognitive performance and risk of mortality: a prospective cohort study of gifted individuals. American Journal of Epidemiology, 162(9), 887-890. 
Mason, C.F. (1956). Pre-illness intelligence of mental hospital patients. Journal of Consulting Psychology, 20(4), 297-300.

Mortensen, E.L., Sørensen, H.J., Jensen, H.H., Reinisch, J.M., \& Mednick, S.A. (2005). IQ and mental disorder in young men. British Journal of Psychiatry, 187(5), 407-415.

Osler, M., Lawlor, D.A., \& Nordentoft, M. (2007). Cognitive function in childhood and early adulthood and hospital admission for schizophrenia and bipolar disorders in Danish men born in 1953. Schizophrenia Research, 92(1-3), 132-141.

Osler, M., McGue, M., \& Christensen, K. (2007). Socioeconomic position and twins' health: a life-course analysis of 1266 pairs of middle-aged Danish twins. International Journal of Epidemiology, 36(1), 77-83.

Pearce, M.S., Deary, I.J., Young, A.H., \& Parker, L. (2006). Childhood IQ and deaths up to middle age: The Newcastle Thousand Families Study. Public Health, 120(11), 1020-1026.

Plomin, R. (2018). Blueprint: How DNA makes us who we are. Cambridge, MA: MIT Press

Plomin, R., \& Deary, I.J. (2015). Genetics and intelligence differences: five special findings. Molecular Psychiatry, 20(1), 98-108.

Plomin, R., \& von Stumm, S. (2018). The new genetics of intelligence. Nature Reviews Genetics, 19, 148. DOI: $10.1038 /$ nrg.2017.104

Ree, M.J., Earles, J.A., \& Teachout, M.S. (1994). Predicting job performance: Not much more than g. Journal of Applied Psychology, 79(4), 518-524.

Richmond-Rakerd, L.S., Caspi, A., Arseneault, L., Baldwin, J.R., Danese, A., Houts, R.M., et al. (2019). Adolescents who self-harm and commit violent crime: testing early-life predictors of dual harm in a longitudinal cohort study. American Journal of Psychiatry, 176(3), 186-195.

Roth, B., Becker, N., Romeyke, S., Schäfer, S., Domnick, F., \& Spinath, F.M. (2015). Intelligence and school grades: A meta-analysis. Intelligence, 53, 118-137.

Santos, I.S., Barros, A.J.D., Matijasevich, A., Domingues, M.R., Barros, F.C., \& Victora, C.G. (2010). Cohort profile: the 2004 Pelotas (Brazil) birth cohort study. International Journal of Epidemiology, 40(6), 1461-1468.

Savage, J.E., Jansen, P.R., Stringer, S., Watanabe, K., Bryois, J., de Leeuw, C.A., et al. (2018). Genome-wide association meta-analysis in 269,867 individuals identifies new genetic and functional links to intelligence. Nature Genetics, 50(7), 912-919.

Schmidt, F., Oh, I.S., \& Shaffer, J.A. (2016). The validity and utility of selection methods in personnel psychology: practical and theoretical implications of 100 years of research findings. Fox School of Business Research Paper. Letöltve: 2020. augusztus 1-jén: https:/ / home. ubalt.edu/tmitch/645/session \% 204/Schmidt\%20\&\%20Oh\%20validity \%20and \% 20 util\%20100\%20yrs\%20of\%20research\%20Wk\%20PPR\%202016.pdf

Shipley, B.A., Der, G., Taylor, M.D., \& Deary, I.J. (2008). Cognition and mortality from the major causes of death: the Health and Lifestyle Survey. Journal of Psychosomatic Research, 65(2), 143-152.

Shurkin, J.N. (1992). Terman's kids: The groundbreaking study of how the gifted grow up. New York, NY, US: Little, Brown and Co.

Silventoinen, K., Modig-Wennerstad, K., Tynelius, P., \& Rasmussen, F. (2007). Association between intelligence and coronary heart disease mortality: a population-based cohort study of 682361 Swedish men. European Journal of Cardiovascular Prevention \& Rehabilitation, 14(4), 555-560.

Smith, D.J., Anderson, J., Zammit, S., Meyer, T.D., Pell, J.P., \& Mackay, D. (2015). Childhood IQ and risk of bipolar disorder in adulthood: prospective birth cohort study. BJPsych open, 1(1), 74-80. 
Spearman, C. (1904). „General intelligence,” objectively determined and measured. The American Journal of Psychology, 15(2), 201-292.

Strenze, T. (2007). Intelligence and socioeconomic success: A meta-analytic review of longitudinal research. Intelligence, 35(5), 401-426.

Strenze, T. (2015). Intelligence and success Handbook of intelligence (405-413). New York, NY: Springer

Toulopoulou, T., Picchioni, M., Mortensen, P.B., \& Petersen, L. (2017). IQ, the urban environment, and their impact on future schizophrenia risk in men. Schizophrenia Bulletin, 43(5), 1056-1063.

Ujma, P.P. (2019). Új eredmények az IQ örökletességéról. Neuropsychopharmacologia Hungarica, 21(2), 69-84.

Urfer-Parnas, A., Lykke Mortensen, E., Saebye, D., \& Parnas, J. (2010). Pre-morbid IQ in mental disorders: a Danish draft-board study of 7486 psychiatric patients. Psychological Medicine, 40(4), 547-556.

Victora, C.G., Barros, F.C., Lima, R.C., Behague, D.P., Gonçalves, H., Horta, B.L., et al. (2003). The Pelotas birth cohort study, Rio Grande do Sul, Brazil, 1982-2001. Cadernos de Saúde Pública, 19, 1241-1256.

Walker, N.P., McConville, P.M., Hunter, D., Deary, I.J., \& Whalley, L.J. (2002). Childhood mental ability and lifetime psychiatric contact: A 66-year follow-up study of the 1932 Scottish Mental Ability Survey. Intelligence, 30(3), 233-245.

Warne, R.T., \& Burningham, C. (2019). Spearman's g found in 31 non-Western nations: Strong evidence that $g$ is a universal phenomenon. Psychological Bulletin, 145(3), 237-272.

Weismann-Arcache, C., \& Tordjman, S. (2012). Relationships between depression and high intellectual potential. Depression Research and Treatment, 2012, 567376. DOI: 10.1155/2012/ 567376

Wraw, C., Deary, I.J., Der, G., \& Gale, C.R. (2016). Intelligence in youth and mental health at age 50. Intelligence, 58, 69-79.

Wraw, C., Deary, I.J., Gale, C.R., \& Der, G. (2015). Intelligence in youth and health at age 50. Intelligence, 53, 23-32.

Wraw, C., Der, G., Gale, C.R., \& Deary, I.J. (2018). Intelligence in youth and health behaviours in middle age. Intelligence, 69, 71-86.

Zammit, S., Allebeck, P., David, A.S., et al. (2004). A longitudinal study of premorbid IQ score and risk of developing schizophrenia,bipolar disorder, severe depression, and other nonaffective psychoses. Archives of General Psychiatry, 61(4), 354-360.

\section{Köszönetnyilvánítás}

Köszönettel tartozom dr. Béres Pálnak (egykori szakdolgozó hallgatómnak) az irodalomkutatásban és a táblázatok összeállításában nyújtott segítségéért. Köszönöm továbbá dr. Bognár Virág és dr. Kovács Kristóf kollégáimnak a kézirathoz fúzött kommentárokat és javaslatokat.

\section{Nyilatkozat érdekütközésról}

A szerző ezúton kijelenti, hogy esetében nem állnak fenn érdekütközések. 


\title{
Cognitive epidemiology - the prospective relationship between intelligence and somatic/psychiatric disease risk
}

\author{
UJMA PRZEMYSLAW, PÉTER
}

Cognitive epidemiology is the science of the relationship between intelligence and health. Modern studies of cognitive epidemiology, often with samples of several hundreds of thousands of individuals, have revealed that higher premorbid intelligence is associated with a lower risk of virtually all of mental illnesses and psychiatric problems. Higher premorbid intelligence is also associated negatively with the incidence of mortality, circulatory illness, metabolic illness, poor health behavior and many diseases of lower epidemiological significance, but its relationship to respiratory illness and non-smoking related cancers is weaker or non-existent. Indicators of adult socioeconomic status do not mediate the association between intelligence and mental illness, but they do partially mediate the relationship with somatic illness and mortality. Studies with special designs - twin control studies, pseudo-experimental studies and molecular genetic studies using Mendelian randomization - suggest that the relationship between intelligence and health is heavily mediated by genetic factors, but somatic health may be modestly but causally improved by better social status as a consequence of higher intelligence.

Keywords: intelligence, IQ, health, leading causes of death, psychiatric illness, cognitive epidemiology

\footnotetext{
A cikk a Creative Commons Attribution 4.0 International License (https:/ / creativecommons.org/ licenses/by/4.0/) feltételei szerint publikált Open Access közlemény, melynek szellemében a cikk bármilyen médiumban szabadon felhasználható, megosztható és újraközölhető, feltéve, hogy az eredeti szerzó és a közlés helye, illetve a CC License linkje és az esetlegesen végrehajtott módosítások feltüntetésre kerülnek. (SID_1)
} 